ALBIAN TO TURONIAN SEDIMENTATION AND MICROFOSSIL ASSEMBLAGES IN

THE NORTHERN WESTERN INTERIOR SEA: PEEL PLATEAU REGION

(NORTHWEST TERRITORIES, CANADA)

\title{
Danielle Thomson
}

A thesis submitted to the Faculty of Graduate Studies in partial fulfillment of the requirements for the degree of

Master of Science

Department of Earth Sciences

Carleton University

Ottawa-Carleton Geoscience Centre

Ottawa, Ontario

September, 2009

(C) Copyright 2009, Danielle Thomson 


\begin{abstract}
Cretaceous sediments in the Northern Interior Plains are widespread and their interbasinal lithostratigraphic correlations indicate several regional disconformities that require biostratigraphic confirmation. This study proposes a new zonation based on benthic foraminifera utilizing the reference section for the Arctic Red and Trevor formations located along the Hume River in the Peel Plateau region (Northwest Territories). Integration of the new temporal framework with detailed sedimentological observations provides an interpretation of the dynamic depositional history for this part of the Western Interior Seaway (WIS).
\end{abstract}

Five foraminiferal zones are recognized, using where possible, zonal markers from previously established biostratigraphic frameworks to facilitate regional correlation with surrounding Western and High Arctic regions. The Early Albian Quadrimorphina albertensis Zone is found in the Martin House and lower Arctic Red formations and is well established in other Arctic regions. The upper part of the Arctic Red Formation is correlated with the newly established Middle to Late Albian Gaudryina canadensis Zone. The top of this zone is marked by a paleosol followed by a nearly barren interval. The Slater River Formation is characterized by the occurrence of fish teeth, Inoceramus prisms, algal cysts, and a single occurrence of Textularia alcesensis, which gives combined evidence for an Early Cenomanian age. The Late Cenomanian Gaudryina irenensis Zone extends through the lower part of the Trevor Formation giving way to the Turonian Pseudoclavulina hastata Zone in the upper Trevor Formation. 
Strata in the Peel Plateau record deposition of the initial transgression of the WIS in two pulses of relative sea-level rise (Martin House Formation) and subsequent offshore marine sedimentation in a deep foreland basin (Arctic Red Formation). The global eustatic sea-level minimum at the Albian-Cenomanian boundary impacted paleogeography in this region with subaerial exposure and paleosol development. Rapid transgression and anoxic bottom waters during the Early Cenomanian (Slater River Formation) resulted in an interval almost barren of foraminifera. During the Turonian, a time of high eustatic sea-level, the study area marks a relatively shallow site where pulses of prograding shorelines are recorded in upward shallowing parasequences bound by pebble lags and flooding surfaces (Trevor Formation).

East of the Peel Plateau in the Mackenzie Plain area, a disconformity separates Albian Arctic Red from ?late Cenomanian-Turonian strata, there named the Slater River Formation. In order to recognize the significant disconformity associated with the loss of Albian foraminifera we propose the use of the Slater River Formation to describe the strata bounded by the erosional horizon and the first pebble bed marking the base of the interbedded mudstones and sandstones of the overlying Trevor Formation. The Hume River section is proposed as the type section for the Slater River Formation. 


\section{ACKNOWLEDGEMENTS}

I would sincerely like to thank my supervisor, Dr. Claudia SchröderAdams for her guidance, time and support throughout this project. It was my great pleasure and honor to work with her. I am indebted to the Northwest Territories Geoscience office for their generous financial support throughout this project. Thank you to Adrienne Jones and the rest of the Peel group for their guidance both in and out of the field. I would especially like to thank Dr. Thomas Hadlari for his mentorship throughout this project. Thank you to Dr. George Dix for many helpful discussions and instruction. Thank you to Peter Jones for help in the SEM and microprobe lab. Thank you to Sheila Thayer for her administrative support. A NSERC Discovery Grant to Dr. Claudia Schröder-Adams also provided funding for this research. Many thanks to other graduate and undergraduate students both for helpful scientific discussions, and more importantly for always keeping a smile on my face. Thank you to my many roommates throughout the past year, particularily for continuing to remind me about good work ethic...

My sincere thanks to my Aunt Lorraine and Uncle Mario for opening their home to me while I have been in Ottawa. Finally I would like to say a heartfelt thank you to my family; to my Dad for introducing a love for the natural sciences to me, to my Mom for her constant love and friendship, and to my brother and sister for being so damn cool. 
TABLE OF CONTENTS

THESIS ACCEPTANCE

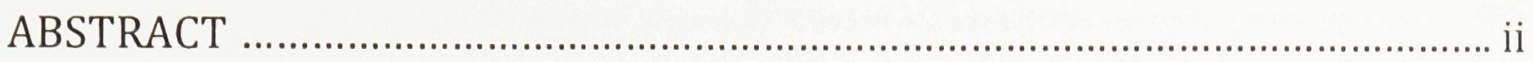

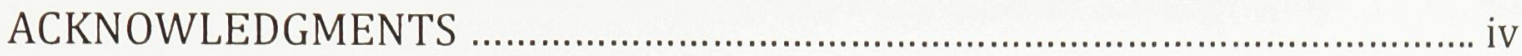

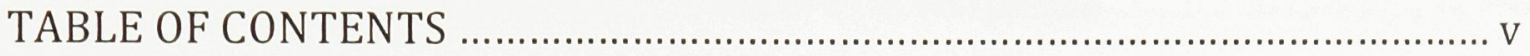

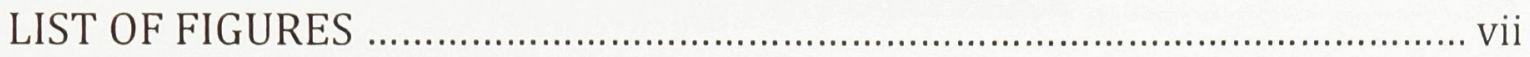

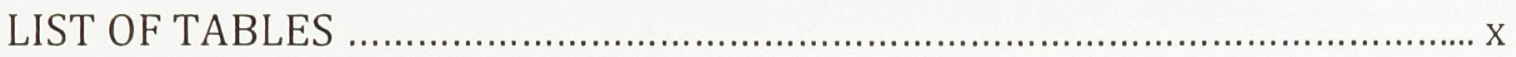

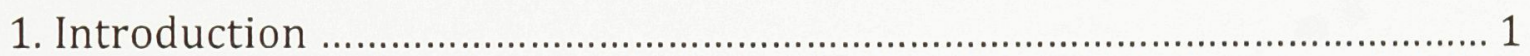

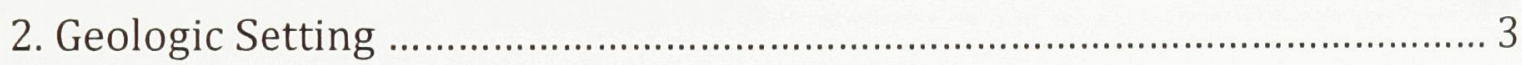

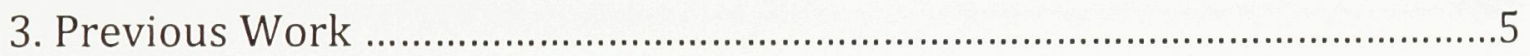

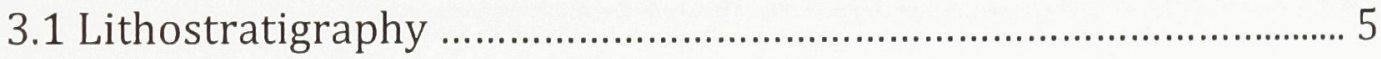

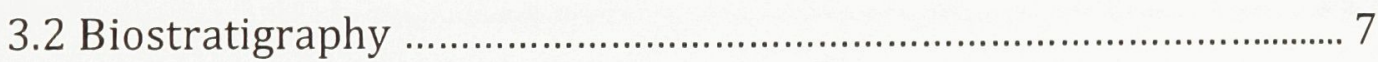

4. Materials and Methods ………….......................................................... 11

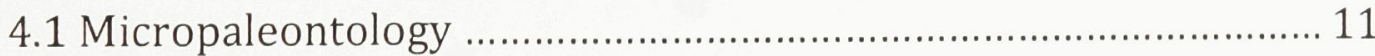

4.2 Sedimentology and Stratigraphy …………................................ 12

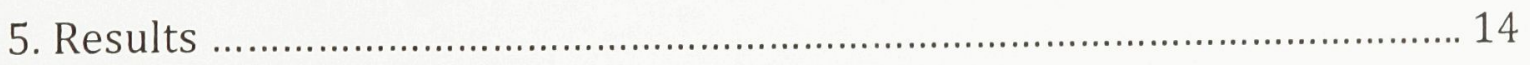

5.1 Facies Descriptions and Interpretations....................................... 14

5.2 Lithology of the Hume River Reference Section ............................ 23

5.3 Gamma Ray Logs ............................................................................ 33 
5.5 Petrology and Geochemistry, Pisoidal Ironstone ........................... 35

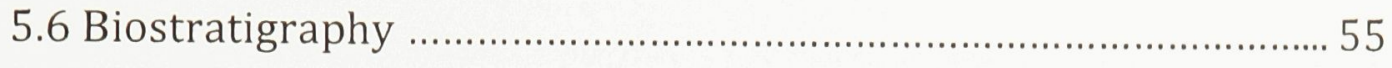

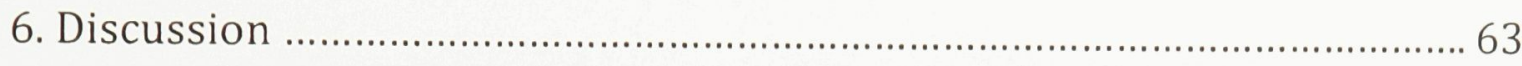

6.1 Stratigraphic Revision en route to Sequence Stratigraphy ............ 63

6.2 Paleogeography and Foraminiferal Response .............................. 72

6.3 Foraminiferal Abundance and Preservation ................................ 73

6.4 Comparison of Biostratigraphy with the Type Section ................. 77

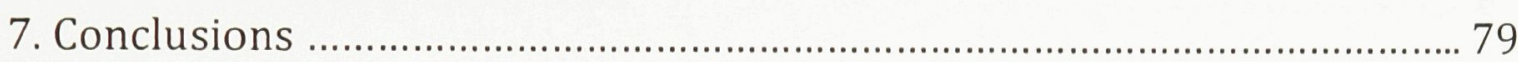

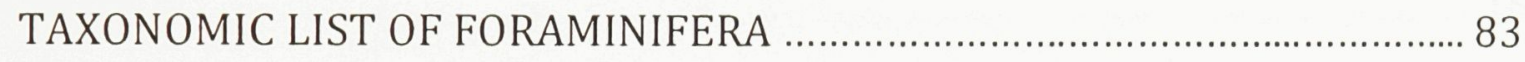

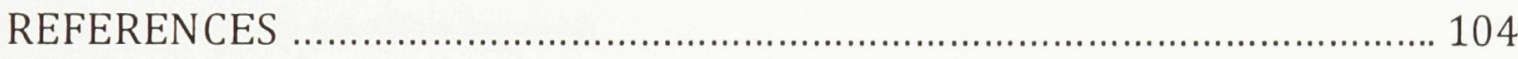

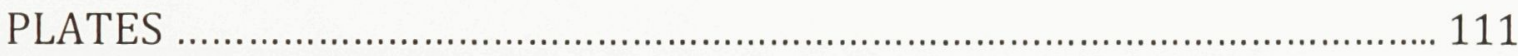

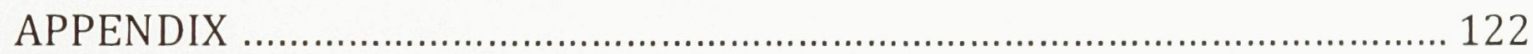




\section{LIST OF FIGURES}

Figure 1. Location map with select regional and tectono elements.

Figure 2. Location of Hume River reference section and Arctic Red F-47 reference well.

Figure 3. Regional stratigraphy. Modified from Dixon, 1999. 7

Figure 4. Foraminiferal biostratigraphic frameworks previously established from north and south of the study area.. 8

Figure 5. Marine profile indicating depositional environments with relative position of facies . .16

Figure 6. Stratigraphic section legend. 25

Figure 7. Measured section and outcrop photos of Martin House Formation .26

Figure 8. Measured section and outcrop photos of Arctic Red Formation 29

Figure 9. Measured section and outcrop photos of Slater River Formation. 31

Figure 10. Measured section of Trevor Formation from Hume River with 21 upwards coarsening parasequences. 34

Figure 11. Example of a typical parasequence from Trevor Formation with representative outcrop photos.

Figure 12. Representative photos from Trevor Formation. 
Figure 13. Hume River lithologic log, gamma ray log measured from outcrop, and gamma ray log from reference well Arctic Red F-47.

Figure 14. HI vs. OI plot of sample data from Hume River section. 42

Figure 15. Outcrop photos of pisoidal ironstone. 43

Figure 16. Photomicrographs of pisoidal ironstone 45

Figure 17. XRD analysis of thin section (top) and apatite-chamosite clay mixture (bottom)

Figure 18. Backscatter images of sample 07-Peel-41 polished thin section. 49

Figure 19. New lithostratigraphic framework and foraminiferal zonation for the Peel region correlated with simplified geology from the Hume River reference section 56

Figure 20. Reported ranges (thin line) of selected foraminiferal species from Cretaceous strata of Alaska (Berquist, 1966; Tappan, 1962), the BeaufortMackenzie area (McNeil, 1996), the Arctic Islands (Sliter, 1981; Wall, 1983); the southern WIS (Caldwell et al., 1993 \& 1978; McNeil and Caldwell, 1981; Mellon and Wall, 1956; Stelck and Leckie, 1990); and this study (thick line)... 57

Figure 21. Foraminiferal species occurences from Hume River section. 58

Figure 22. Interpreted sea-level curve for Peel region. 65 
Figure 23. Diagrammatic cross section of Peel Plateau and Mackenzie Plain stratigraphy.

Figure 24. Paleogeographic maps of WIS from Early Albian to Early Turonian. Star indicates study area. 74 


\section{LIST OF TABLES}

Table 1. Table with facies and facies interpretations

Table 2. Rock-Eval data from Hume River section.

Table 3. Electron probe microanalysis (EPMA) analysis from carbonate cement of sample 07-Peel-41.

Table 4. EPMA analysis from apatite-chamosite clay mixture of a pisoid. 52

Table 5. EPMA analysis of glaucony from sample 07-Peel-41. 54 


\section{INTRODUCTION}

This study was undertaken in collaboration with the Northwest Territories Geoscience Office's (NTGO) Peel Plateau Petroleum Geoscience Project, a multi-year project that involved joint participation from federal, territorial, and academic researchers. The purpose of the project was to address the need for up-to-date research on the petroleum potential of the Paleozoic and Mesozoic sedimentary successions in the region. Rationale for this was the close proximity of the proposed Mackenzie Gas Project pipeline route to the study area as well as Canada's sovereignty in the north. Several thematic studies were conducted in conjunction with a large synthesis volume (Pyle and Jones, 2009). The purpose of my contribution is to provide a biostratigraphic framework utilizing foraminiferal assemblages for the Cretaceous succession in the Peel region, set in context of detailed sedimentology and sequence stratigraphy.

The Peel Plateau and Plain region, Northwest Territories, is located northeast of the Mackenzie Mountains and follows a general arcuate trend along the front of the mountain belt (Fig. 1). During the Cretaceous, sediments were deposited in a foreland basin that developed as a result of the Columbian orogeny (Dixon, 1999). Cretaceous strata are subdivided into the Martin House, Arctic Red, Slater River, and Trevor formations and span the Early Albian to Turonian.

Previously, ages of Cretaceous strata in the Peel region were poorly constrained. The type section at the Peel River (Fig. 1) is a composite section where the unconformable contact to the underlying Paleozoic is unknown and the upper 
portion of the section was inaccessible for sampling (Mountjoy and Chamney, 1969), which causes uncertainties in the stratigraphy. Also, the original biostratigraphic framework contains zonal markers that do not facilitate correlations to neighbouring regions. Several unconformities have been reported throughout the

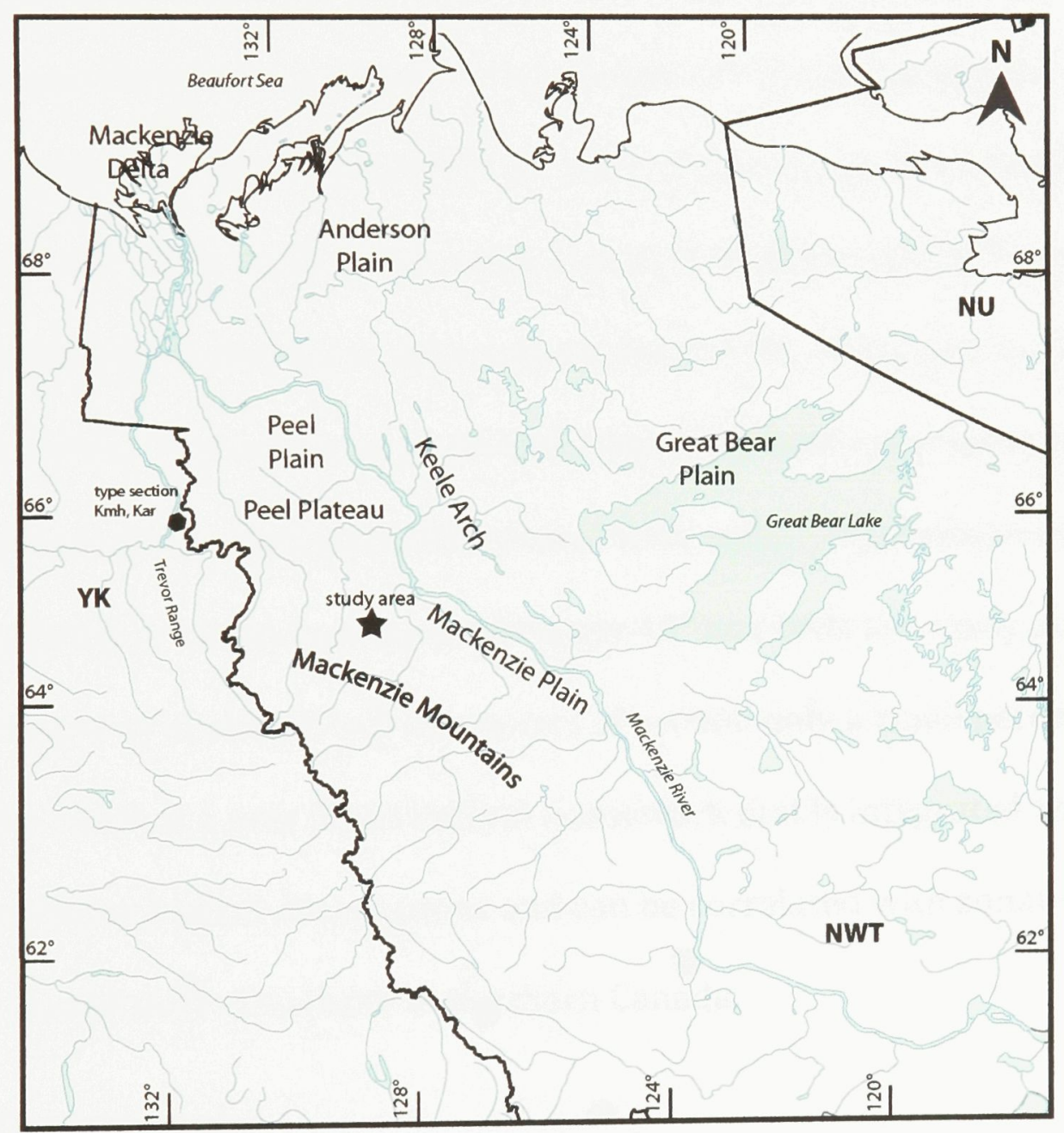

Figure 1. Location map with select regional and tectono elements. (Kmh - Martin House Formation, Kar - Arctic Red Formation) 
Cretaceous in northern Canada, however prior to this study, it was only hypothesized that strata in the Peel region do not represent continuous sedimentation (e.g. Dixon, 1999). In thick shale successions associated with foredeep settings, biostratigraphic data become necessary for stratigraphic correlations, temporal frameworks and detection of unconformable surfaces.

Foraminifera have delivered useful biostratigraphic zonations for the Cretaceous of Western Canada and have served as paleoenvironmental proxies in order to unravel the complex sea-level history of the Cretaceous period. In remote regions of northern Canada, studies rely primarily on outcrop data due to the limited amount of subsurface data. This study is the result of field work from the 2007 summer season, in which the Hume River reference section for the Cretaceous in the Peel region is revisited. This section is a valuable locality for biostratigraphic studies for several reasons: a) the unconformable contact with underlying Paleozoic rocks is exposed, b) strata are dipping at approximately $45^{\circ}$ and beds are easily accessible for sampling and c) in almost two kilometers of section only a small percentage is covered. The result is a new foraminiferal framework that is integrated with detailed sedimentological observations and can be correlated with zonations previously established elsewhere in Northern Canada.

\section{GEOLOGIC SETTING}

The Peel region is host to thick deposits of Cretaceous-age strata and is a link between northern deposits in the Beaufort-Mackenzie area and more extensively studied deposits of the Cretaceous Western Interior Seaway (WIS) in northern 
Alberta and British Columbia. Sediments were deposited within the Peel Trough (Fig. 1), a foreland basin that developed adjacent to the Mackenzie Mountains during the Colombian Orogeny (Yorath and Cook, 1981). Crustal loading at the front of the advancing mountain belt resulted in the development of a foredeep, providing accommodation space for thick clastic deposits. Strata in the Peel region record subsidence and gradual infill of this basin.

The Keele Arch (Cook, 1975) was a positive structural feature which separated part of the Peel Trough to the west from the Great Bear Basin to the east (Fig. 1). There has been debate as to whether this structure was a paleotopographic high at the onset of deposition of Cretaceous strata (Yorath and Cook, 1981), or if it was activated during post-Albian time (Williams, 1989). Recent work by Hadlari et al. (2009) has shed light on the evolution of this part of the foreland basin. Sediments sourced from the craton to the east were reworked within the Peel Trough and deposited in a westerly-deepening basin during Albian time. These sediments onlap the Keele Arch, supporting the existence of a structural high during the Albian. With continued crustal loading during Cenomanian to Turonian time, the foredeep migrated eastward and the source of sediments shifted to the rising mountains in the west. These sediments, now deposited in an eastward-deepening basin, onlap and eventually cover the Keele Arch.

The Cretaceous was a period of large scale eustatic sea-level changes, and this, coupled with active tectonism in the Canadian Cordillera is reflected in the regional transgressive-regressive (T-R) events throughout the Western Interior 
Seaway (WIS). The Peel region provides a valuable link between the more consistently marine deposits of the Boreal Sea and their contemporaneous southern counterparts in a variable epicontinental sea.

\section{PREVIOUS WORK}

\subsection{Lithostratigraphy}

Cretaceous strata in the Peel region were previously subdivided into the Martin House, Arctic Red, and Trevor formations. Originally defined by Mountjoy and Chamney (1969), the type section for the Martin House and Arctic Red formations is a composite section located along the Peel River close to its junction with the Snake River. The Trevor Formation (Mountjoy and Chamney, 1969) is only described from its type area at the Cranswick River with no continuous section description. Exposures in the Trevor Range are considered a supplemental type section in which the lower part of the formation is exposed (Mountjoy and Chamney, 1969). Yorath and Cook (1981) proposed a reference section for the Arctic Red and Trevor formations along the Hume River (Fig. 2), where the subCretaceous unconformity is preserved. Consequently, the reference section should take preference over the type section which is a composite section lacking the basal contact to the underlying Paleozoic strata. Furthermore, beds that outcrop in the type area are nearly horizontal making the top of the section inaccessible for measuring and sampling strata.

Nomenclature of stratigraphic units between formations in the study area and neighbouring regions is somewhat inconsistent and has been revised in several 


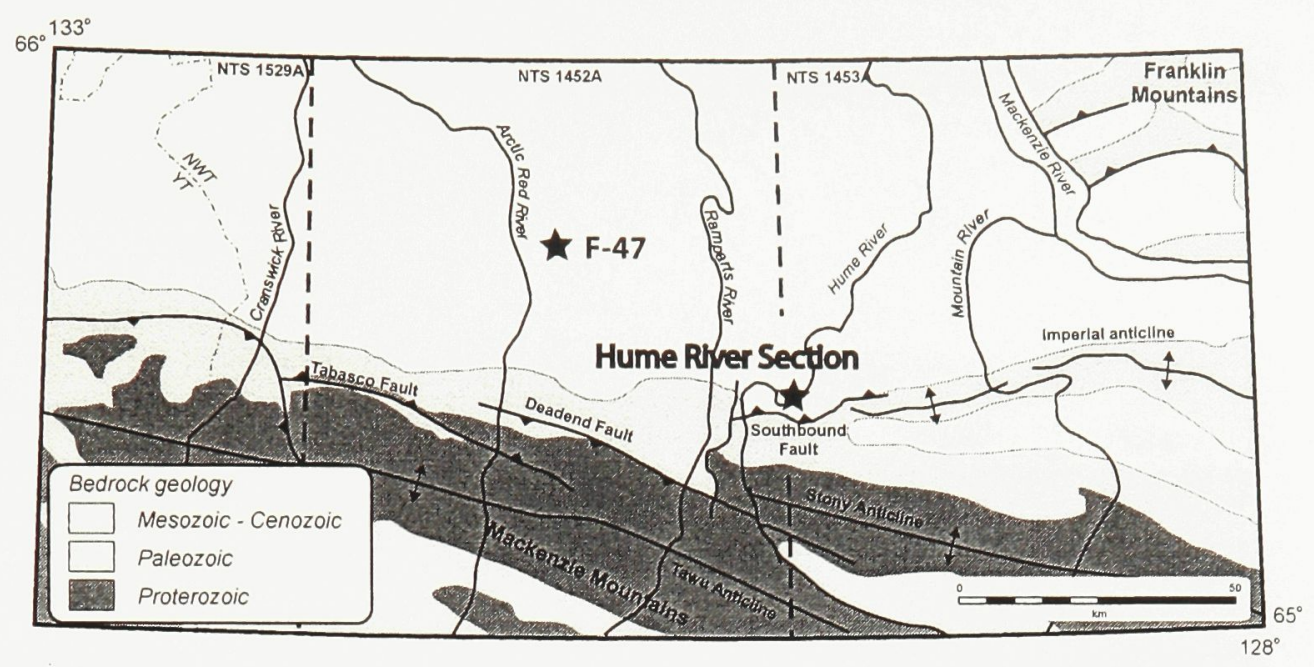

Figure 2. Location of Hume River reference section and Arctic Red F-47 reference well.

studies (e.g. Yorath and Cook, 1981; Dixon, 1999). Martin House and Arctic Red formations can be correlated across the Peel Plateau, Mackenzie Plain, and Great Bear Plain (Fig. 3). The Slater River Formation has recently been introduced for the Peel Plateau (Hadlari et al., 2009) and extends into the Mackenzie Plains area.

Trevor Formation is only used in Peel Plateau, however is probably in part correlative with sandstones of the Little Bear Formation in the Mackenzie Plains and Dunvegan Formation in the Liard Plateau.

Detailed lithologies and sedimentological interpretations for these formations are lacking in the studies by Mountjoy and Chamney (1969) and Yorath and Cook (1981), both of which were large-scale mapping projects. Recently, Hadlari et al. (2009) has given a detailed description of the sedimentology and stratigraphy for 
the Cretaceous in the Peel region. This thesis will address specifically the reference section along the Hume River and tributaries and integrates microfossil data with sedimentological observations.

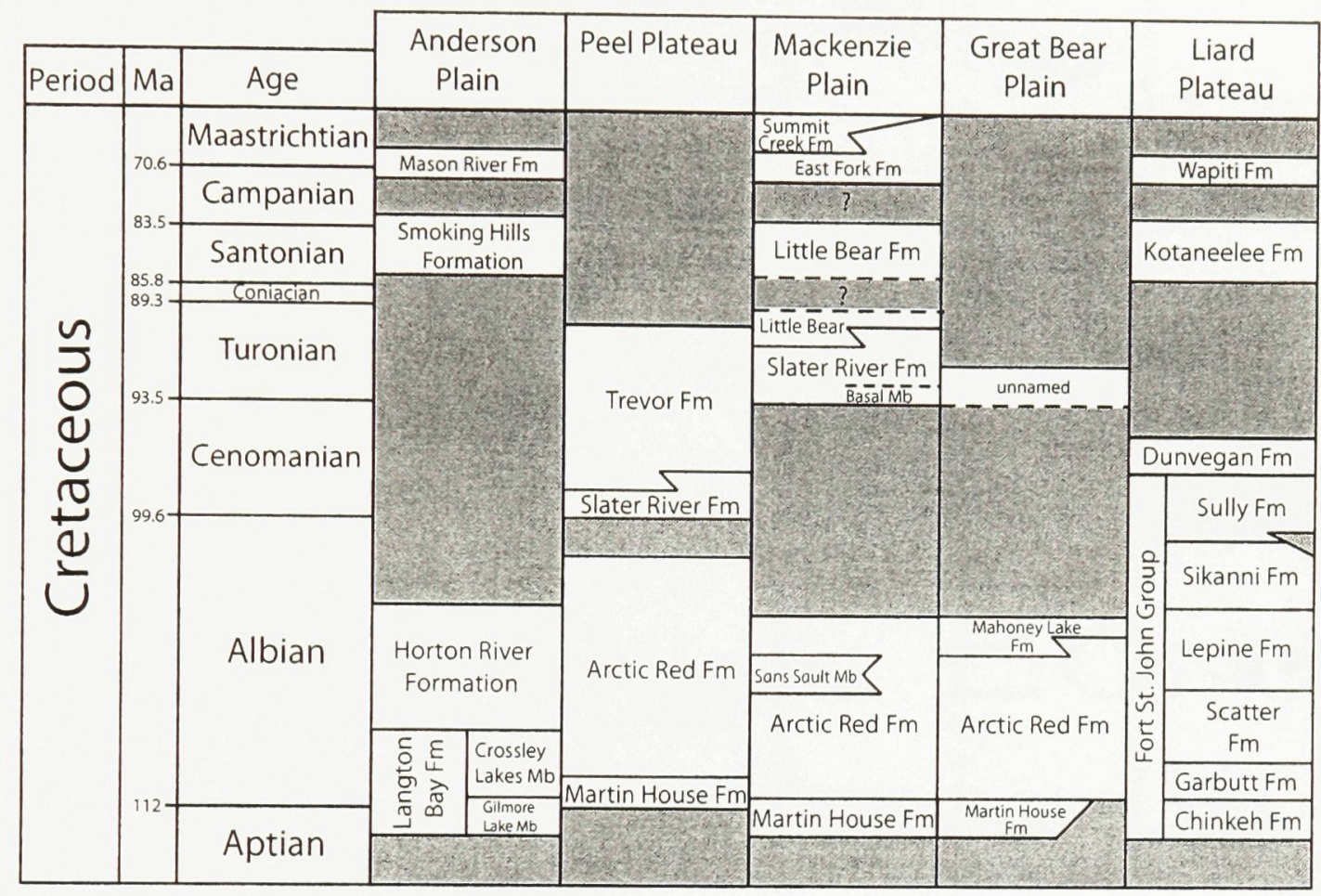

Figure 3. Regional stratigraphy. Modified from Dixon, 1999.

\subsection{Biostratigraphy}

Original age determinations based on a foraminiferal stratigraphic framework were given by Mountjoy and Chamney (1969) and modified by Chamney (1978). An Aptian to Early Albian age was assigned to the Martin House Formation; the Arctic Red and Trevor formations were considered time correlative with a 


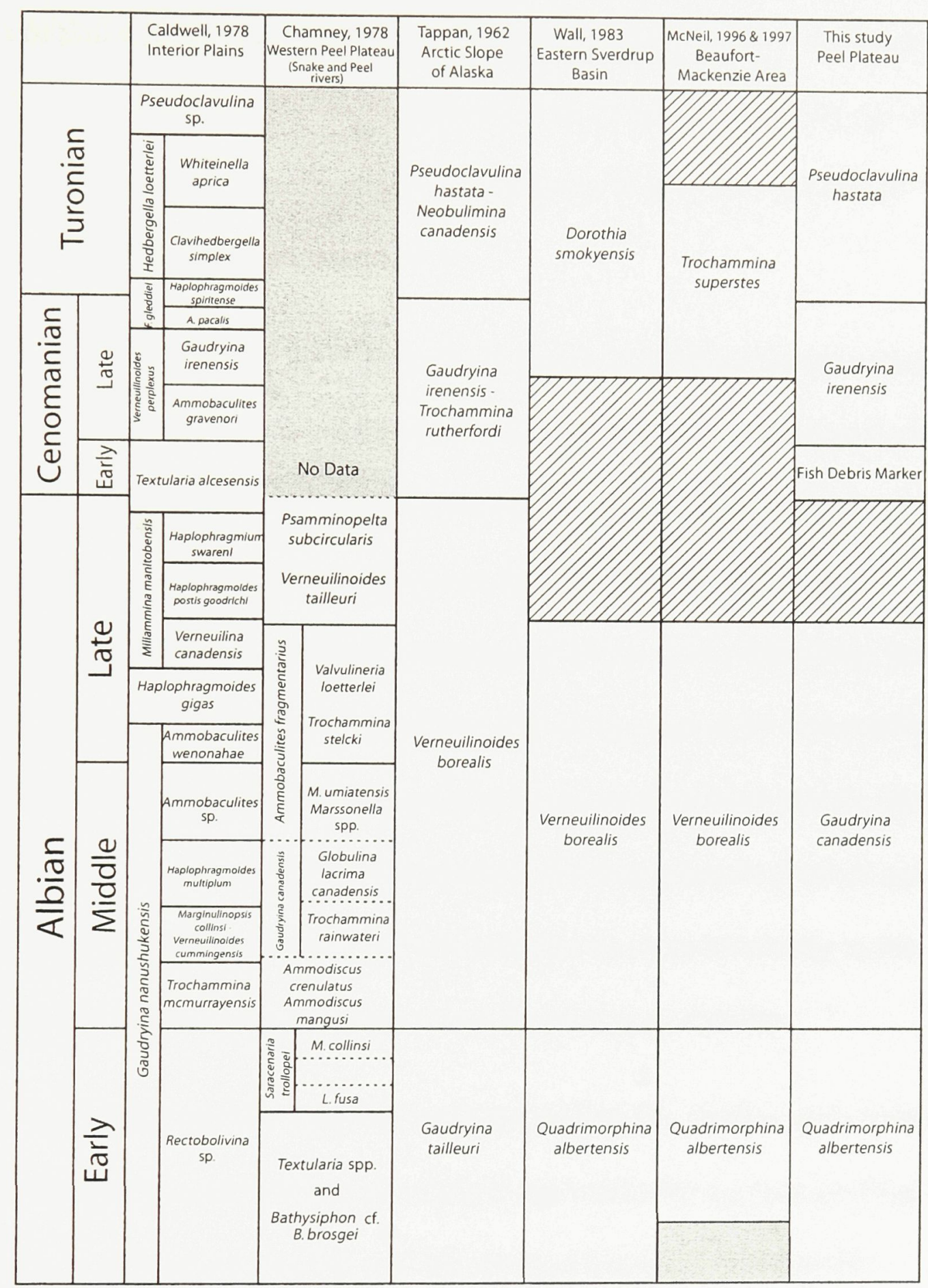

Figure 4. Foraminiferal biostratigraphic frameworks previously established from north and south of the study area. New zonation for Peel Plateau is shown on the far right. 
Middle-Late Albian age for the Arctic Red Formation and latest Early to Late Albian age for the Trevor Formation (Fig. 4). Yorath and Cook (1981) revised the age of the Trevor Formation extending its range into the Turonian based on macrofossils collected from outcrop along the Hume River.

Dixon (1999) reported on a regionally extensive unconformity separating Albian and Cenomanian strata in northern Canada. This break in sedimentation had not been documented in the Peel region, however, Dixon (1999) postulated that an event of such extent should be present there as well. East of the Peel, in the Mackenzie Plain region, this unconformity separates Albian Arctic Red strata from the overlying Turonian Slater River Formation (Fig. 3). The age of the Slater River Formation is poorly constrained and has reported ages ranging from Middle Albian to Turonian based on palynomorphs, foraminifera, and macrofossils (Yorath and Cook, 1981). These age discrepancies are attributed to its close proximity to the Keele Arch, which results in a diachronous base depending on locality.

There have been several foraminiferal biostratigraphic studies undertaken in northern Canada that provide valuable existing frameworks for correlation (Fig. 4) with this study, as well as the already well-established frameworks from the southern Western Interior Basin (Caldwell et al., 1978, 1993). Integral to this study were established zonations for the Arctic Slope of Alaska (Bergquist, 1966; Tappan, 1962), the Beaufort-Mackenzie area (McNeil, 1996, 1997b), the Arctic Islands (Sliter, 1981; Wall, 1983), and the southern Western Interior Basin (Caldwell et al., 
1993; Caldwell et al., 1978; McNeil and Caldwell, 1981; Mellon and Wall, 1956b;

Stelck and Leckie, 1990). The original foraminiferal studies for the Peel region were provided by Chamney (Mountjoy and Chamney, 1969; Chamney, 1978).

Most zonal markers used in these frameworks are agglutinated taxa, which tend to range longer than calcareous species. The Albian is represented by two zones in the Arctic Slope of Alaska, Eastern Sverdrup Basin, and Beaufort-Mackenzie area, which separate the Early from the Middle to Late Albian. The Early Albian is marked by the occurrence of Gaudryina tailleuri on the Arctic Slope, whereas Quadrimorphina albertensis occurs in the Eastern Sverdrup Basin and BeaufortMackenzie areas. The Middle to Late Albian is represented by Verneuilinoides borealis in all three of these regions. The Albian zonation originally proposed for the Peel by Chamney (1978) includes six different zones and several subzones, none of which can be correlated elsewhere (Fig. 4). There is less geographic uniformity in the zonations for the Cenomanian and Turonian. The Cenomanian of the Arctic Slope of Alaska is characterized by the Gaudryina irenensis/Trochammina rutherfordi Zone overlain by the Turonian Pseudoclavulina hastata/Neobulimina canadensis Zone (Tappan, 1962). The Dorothia smokyensis Zone covers the Upper Cenomanian/Turonian interval in The Eastern Sverdrup Basin (Wall, 1983), which is correlative to the Trochammina superstes Zone in the Beaufort-Mackenzie area (McNeil, 1996). The Upper Cretaceous interval is not documented from Mountjoy and Chamney's 1969 and Chamney's 1978 reports (Fig. 4). 


\section{MATERIALS AND METHODS}

This study includes 107 micropaleontological samples and 10 hand samples collected from the Martin House, Arctic Red, Slater River and Trevor formations

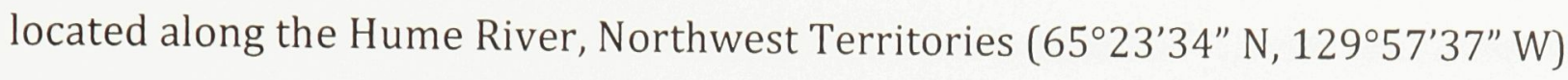
(Fig. 2). The section was measured and sampled during the 2007 summer field season for foraminiferal biostratigraphic and sedimentological analysis.

\subsection{Micropaleontology}

The measured section is $1869.5 \mathrm{~m}$ thick and outcrop samples were collected approximately every $20 \mathrm{~m}$ or where lithology showed distinctive changes. Samples were taken from shaley intervals, and preference was given at critical horizons, such as flooding surfaces.

Samples for foraminiferal analysis were broken down according to the standard method described by Then and Dougherty (1983). Foraminifera were picked from the sand sized fraction $(>63 \mu \mathrm{m})$. Volume of material picked varied on amount of residue available. Numerous samples were barren of foraminifera or had poorly preserved specimens allowing for identification to genus at best. This, combined with overall low abundance did not allow for statistical analysis. Total counts of foraminifera are listed in the Appendix. Identification of species was performed under a binocular light microscope and identifications were based on original descriptions. Photomicrographs of representative examples of species identified were taken with a Sony Cyber-shot digital camera mounted on a binocular microscope. 


\section{Scanning Electron Microscopy}

Specimens were examined on a JEOL 6400 digital scanning electron microscope interfaced to a Link Systems eXL-LZ4 energy-dispersive x-ray analyzer operated at $20 \mathrm{kv}$ accelerating potential and a beam current of $1.0 \mathrm{nA}$. Foraminifera were mounted on aluminum stubs with an adhesive tape, coated with a thin film of gold and palladium, and observed in secondary electron mode. Digital images were collected at $1024 \times 768$ pixel resolution on a SEMages PC based digital imaging system.

\subsection{Sedimentology and Stratigraphy}

Shale micropaleontological samples were sub-sampled for Rock Eval/Total Organic Content (TOC) pyrolysis and sent to Geological Survey of Canada - Calgary for analysis. Gamma ray measurements were taken approximately every $15 \mathrm{~m}$ with a scintillometer for correlation of outcrop to subsurface.

A hand sample (sample 07-Peel-41) of a pisoidal ironstone forming an important stratigraphic horizon was collected for petrography, X-ray diffraction (XRD), and electron probe microanalysis (EPMA). Textural analysis of this sample was studied from thin sections prepared at Carleton University using standard microscopy techniques under transmitted light (TL). XRD analysis was done on a thin section as well as powder collected from the hand sample. A dental drill was used to collect powder from distinct minerals within the rock. The powders were then ground with water by a mortar and pestle until a slurry-like consistency was 
achieved, and allowed to dry overnight before running analysis. The diffractometer at Carleton University was used to collect data from $3^{\circ}$ to $60^{\circ}$ in $0.02^{\circ} 2 \theta$ steps.

\section{Electron Probe Microanalysis}

Quantitative analyses were made on an automated 4 spectrometer Cameca Camebax MBX electron probe by the wavelength dispersive x-ray analysis method (WDX). Operating conditions were: $15 \mathrm{kv}$ accelerating voltage, 20 nano-amperes beam current. Counting times were $15-60$ seconds or 40,000 accumulated counts. Background positions were carefully selected to avoid instances of peak overlap. Background measurements were made at $50 \%$ peak counting time on each side of the analyzed peak. During analysis, the electron beam was rastered over an area of approximately 5-8 microns x 5-8 microns to minimize beam damage to the specimen. Raw x-ray data were converted to elemental weight $\%$ by the Cameca PAP matrix correction program. A suite of well characterized natural and synthetic minerals and compounds were used as calibration standards. Analyses are accurate to $1-2 \%$ relative for major elements, $3-15 \%$ relative for minor elements ( 0.1 - 1 wt.\%). Specimens were also examined with an EDX (energy-dispersive x-ray analysis) system to confirm mineral identifications and determine the presence or absence of major and trace elements prior to quantitative analysis. 


\section{Electron Microprobe Imaging}

Digital BSE (back-scattered electron) images were collected at 512 x 512 pixel resolution with an Electron Optic Services digital imaging system consisting of: a 4Pi Analysis Inc. digital imaging and EDX x-ray system and Power Macintosh G3 computer interfaced to at a Lamont 4 element solid state BSE detector and BSE Quad Summing Amplifier, Kevex EDX detector, and Aptec spectroscopy amplifier.

\section{RESULTS}

\subsection{Facies Descriptions and Interpretations}

Sedimentological studies of the Martin House, Arctic Red, Slater River, and Trevor formations located along the Hume River (Fig. 2) resulted in identification of 11 distinct facies identified within the four formations (Table 1). A profile of the relative positions of depositional environments with respect to facies is given in Figure 5 .

Facies 1: Pebble facies

The pebble facies is found at the base of the Martin House Formation at the contact with the sub-Cretaceous unconformity and in the Trevor Formation on top of amalgamated sandstone beds. Beds in this facies are up to $15 \mathrm{~cm}$ thick. In the Martin House, the lithology is a monomict chert, matrix-supported pebbly sandstone conglomerate. Chert pebbles are subrounded and 0.3 to $5 \mathrm{~cm}$ in diameter in a matrix of fine-grained sandstone. Beds are massive, ungraded, and poorly sorted. In the Trevor Formation, this facies is generally represented by conglomerates with pebble 
to cobble size, flat, ellipsoid clasts. This facies is interpreted to represent

transgressive lags deposited in a foreshore environment. For the Martin House, the

\begin{tabular}{|c|c|c|c|}
\hline Facies \# & Facies Name & Formation & Interpretation \\
\hline F1 & Pebble facies & Martin House, Trevor & Transgressive lag deposits \\
\hline $\mathrm{F} 2$ & $\begin{array}{l}\text { Cross-stratified strongly } \\
\text { bioturbated facies }\end{array}$ & Martin House & $\begin{array}{l}\text { Fully marine lower shoreface depositional } \\
\text { environment }\end{array}$ \\
\hline F3 & $\begin{array}{l}\text { Cross-stratified fine- } \\
\text { grained sandstone facies }\end{array}$ & Martin House & $\begin{array}{l}\text { Waning storm deposits preserved in the } \\
\text { middle to lower shoreface. }\end{array}$ \\
\hline F4 & Mudrock facies & $\begin{array}{l}\text { Martin House, Arctic Red, Slater } \\
\text { River, Trevor }\end{array}$ & $\begin{array}{l}\text { Offshore marine environment subject to } \\
\text { rare, intermittent storm generated } \\
\text { currents }\end{array}$ \\
\hline F5 & $\begin{array}{l}\text { Interstratified shale, } \\
\text { siltstone, and cross- } \\
\text { laminated fine grained } \\
\text { sandstone facies }\end{array}$ & Arctic Red, Slater River, Trevor & $\begin{array}{l}\text { Transition between offshore marine and } \\
\text { lower shoreface, above storm wave base } \\
\text { but below fair-weather wave base. Where } \\
\text { present in Trevor Formation, this facies } \\
\text { does not have HCS. }\end{array}$ \\
\hline F6 & Pisoidal ironstone facies & Arctic Red & Paleosol \\
\hline F7 & $\begin{array}{l}\text { Black carbonaceous shale } \\
\text { facies }\end{array}$ & Slater River & $\begin{array}{l}\text { Restricted marginal marine to terrestrial } \\
\text { setting, possibly a lagoon or bog }\end{array}$ \\
\hline F8 & $\begin{array}{l}\text { Radioactive mudrock } \\
\text { facies }\end{array}$ & Slater River & $\begin{array}{l}\text { Condensed section in an offshore marine } \\
\text { environment }\end{array}$ \\
\hline F9 & $\begin{array}{l}\text { Interbedded sandstone } \\
\text { and mudrock with HCS } \\
\text { facies }\end{array}$ & Trevor & $\begin{array}{l}\text { Wave-dominated lower shoreface } \\
\text { environment. }\end{array}$ \\
\hline F10 & $\begin{array}{l}\text { Amalgamated sandstone } \\
\text { facies }\end{array}$ & Trevor & Storm-dominated middle shoreface \\
\hline F11 & $\begin{array}{l}\text { Bioturbated medium- } \\
\text { grained sandstone facies }\end{array}$ & Trevor & Upper shoreface \\
\hline
\end{tabular}

Table 1. Table with facies and facies interpretations. 


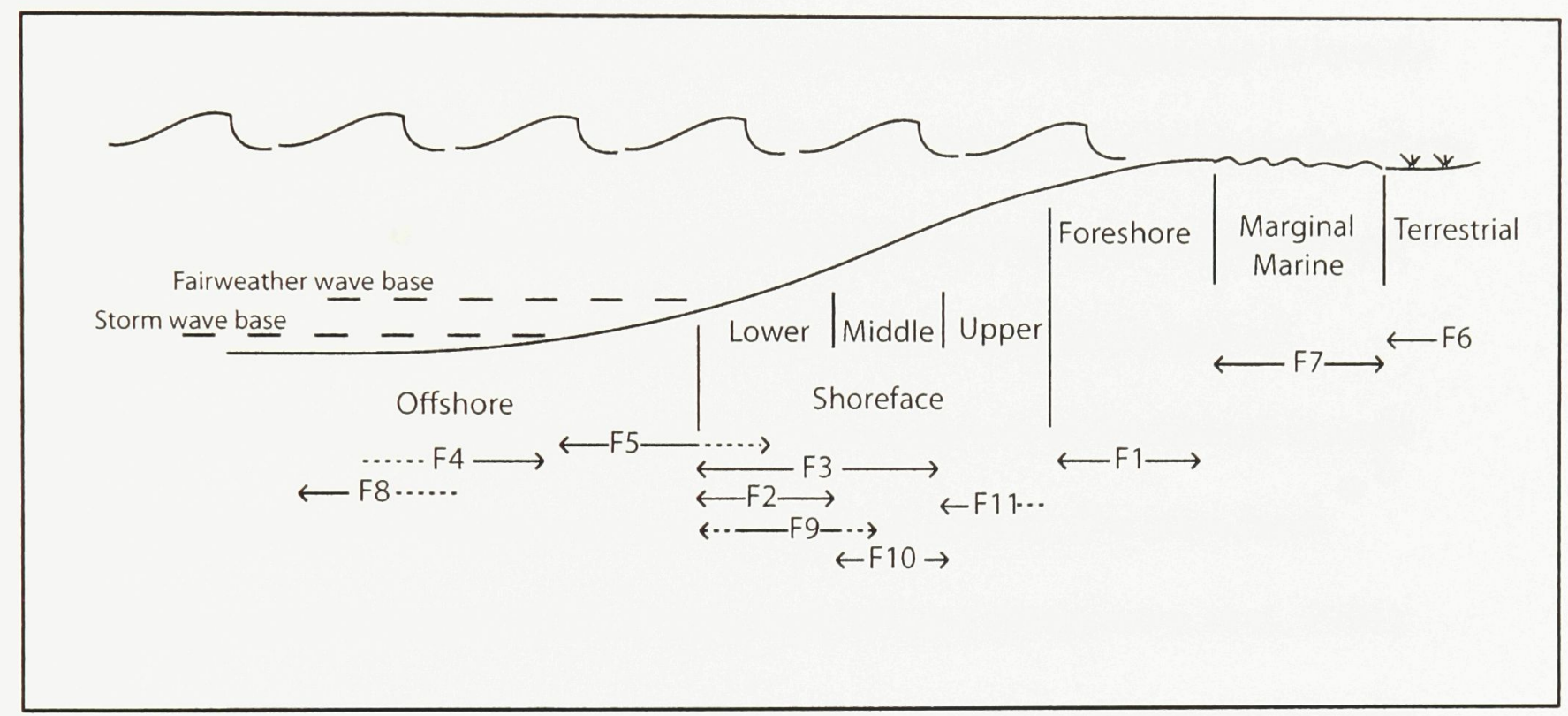

Figure 5. Marine profile indicating depositional environments with relative positions of facies. Modified from Walker and Plint, 1992. 
facies is interpreted to represent reworked material at the onset of transgression of the Cretaceous seaway, evidenced by the chemical maturity of the clasts and rounding of the grains.

Facies 2: Cross-stratified strongly bioturbated facies

Facies 2 is found in the Martin House Formation and is moderate to heavily bioturbated, medium to fine grained sandstones interstratified with lesser interbeds of mudrock and siltstone. Ichnofossils include Skolithos, Chondrites, Rosselia, and Thalassinoides. In places, bioturbation is so pervasive it has obliterated all sedimentary structures. Where sedimentary structures are still visible, low-angle cross stratification and ripple cross laminations are present. The trace fossil assemblage is characteristic of the Cruziana ichnofacies (Pemberton et al., 2001). This, coupled with the grain size and sedimentary structures preserved indicates that this facies represents a fully marine lower shoreface depositional environment.

Facies 3: Cross-stratified fine-grained sandstone facies

Facies 3 is found in Martin House Formation and is composed of fine-grained sandstone. Sedimentary structures preserved include low-angle cross-stratification, ripple cross-lamination, and occasional HCS. In places, a succession of bedforms from low-angle cross stratification through HCS to ripple cross-lamination is preserved, representing a decrease in energy. This facies is interpreted to represent waning storm deposits preserved in the middle to lower shoreface. 
Facies 4: Mudrock facies

The mudrock facies is present at the top of the Martin House Formation, throughout Arctic Red and Slater River formations, and at the base of parasequences within Trevor Formation. This facies consists of dark grey to black, poorly indurated shale and mudrock that create unstable slopes. Thin 1-10 cm thick beds of finegrained sandstone or siltstone may be present. Sedimentary structures are uncommon, but consist of rare cone-in-cone structures and ripple cross laminae within coarser grained beds of siltstone and sandstone. Millimeter to centimeter thick bentonite beds are present in lower to middle Arctic Red and lower Slater River Formations. There are common ellipsoidal to planar siderite concretions, which range from several centimeters to tens of centimeters in diameter distributed along bedding planes. In the Slater Formation, concretions may have coalified wood at the core. Rare ammonites and bivalves (?Inoceramus) are found in Arctic Red Formation, and may be preserved in the cores of concretions. Vertical traces of Teichichnus and rare small horizontal burrows are present. Teichichnus is associated with the Cruziana Ichnofacies, indicative of lower shoreface to offshore marine (Pemberton et al., 2001). This facies is interpreted to represent deposition in an offshore marine environment that was subject to rare, intermittent storm generated currents. 
Facies 5: Interstratified shale, siltstone, and cross-laminated fine grained sandstone facies

Facies 5 is present in Arctic Red, Slater River, and Trevor formations. Its dominant lithology is shale with minor coarsening upward, interstratified shale, siltstone and sandstone. Siltstone beds are up to $1 \mathrm{~cm}$ thick and may pinch and swell. Sharp-based fine-grained sandstone beds are up to $30 \mathrm{~cm}$ thick and spaced 5$150 \mathrm{~cm}$ apart. Tops of sandstone beds have variable lateral thickness, which reflects the amount of sand size material available. Sedimentary structures include lowangle cross-stratification, rare HCS, ripple cross-lamination, and 2D and 3D ripples that can be seen on bedding surfaces. In cross section, ripple cross-lamination may show a preferred climbing direction. There are rare beds of massive fine-grained sandstone with mud rip-up clasts within. Ichnofossils include indeterminate horizontal burrows and escape structures infilled with overlying sediment. Escape structures and climbing ripples infer rapid deposition. HCS supports that this environment was subject to periodic storm reworking, with ripples preserving the last of waning storm energy. This facies is interpreted to represent distal storms that transported what sand size sediment was available. Shale reflects background suspension-dominated sedimentation during quiescent periods. This facies is interpreted to represent transition between offshore marine and lower shoreface, above storm wave base but below fair-weather wave base. Where present in the Trevor Formation, this facies does not have HCS. 
Facies 6: Pisoidal ironstone facies

Facies 6 is only found at the top of Arctic Red Formation. It is characterized by $10-15 \mathrm{~cm}$ thick beds of pisoidal ironstone with shale interbeds. The pisoidal ironstone is matrix supported with centimeter-size pisoids. The matrix is composed of siderite; the pisoids are replaced by siderite and a chamosite-apatite clay mixture. There are rare wood fragments present. This facies is interpreted to represent a paleosol that has undergone subsequent diagenesis and the petrology and geochemistry will be further discussed below (see Chapter 5.5).

Facies 7: Black carbonaceous shale facies

Facies 7 is found only in the Slater River Formation, overlying pisoidal ironstone facies. Black carbonaceous shale facies consists of rare coal seams within black carbonaceous shales. Type III organic matter with high OI values (see Fig. 14) suggests terrestrial sources. The depositional environment is interpreted to represent a restricted marginal marine to terrestrial setting, possibly a lagoon, marsh, or bog where terrestrial material can accumulate.

Facies 8: Radioactive mudrock facies

Facies 8 is represented by a 10 -cm-thick bed in the Slater River Formation and is distinguished by a high ( $>300$ api) gamma ray value. In outcrop it is a poorly consolidated mudrock that is dark black in colour. Residue from the microfossil sample at this horizon contained phosphate in the form of fish teeth, the probable cause for an elevated gamma reading, as well as cubic pyrite. This facies represents 
a condensed section in an offshore marine environment at the peak of a rapid transgression and switch to highstand systems tract, where sediment input to the system is minimal.

Facies 9: Interbedded sandstone and mudrock with HCS facies

Facies 9 is present in the Trevor Formation and consists of interbedded mudrock and fine-grained sandstone, with lesser siltstone. Sandstone beds are 5-30 $\mathrm{cm}$ thick interbedded every $20-50 \mathrm{~cm}$ between mudrock intervals. Sedimentary structures consist of low-angle cross-stratification, HCS, parallel lamination, and ripple-cross lamination. Rare horizontal and vertical burrows occur in both sandstone and mudrock lithologies. Rare wood fragments are present. This facies is similar to Facies 5, however, HCS and parallel laminated bedforms as well as greater abundance of sand-size sediment suggest a greater energy regime. Where present, this facies shows a coarsening upward trend, and is a transition between Facies 5 and amalgamated sandstone facies (Facies 10, see below). It is interpreted to preserve sediments deposited in a wave-dominated lower to middle shoreface environment.

Facies 10: Amalgamated sandstone facies

Facies 10 is found in the Trevor Formation and is characterized by finegrained sandstone. Sandstone beds are $>30 \mathrm{~cm}$ and may be up to several meters thick. Scours are present on erosional bases of sandstones. Sedimentary structures include HCS, rare swaley cross-stratification (SCS), low-angle cross-stratification, parallel or wavy lamination, 2D and 3D ripple cross-lamination. Primary current 
lineation on parallel laminated beds is visible in planform. Ball-and-pillow soft sediment deformation structures are rare and concretions within sandstone can also be present. Traces may include rare horizontal and vertical burrows.

This facies reflects storm deposits that have been stacked on one another. In places, a full succession of bedforms from a waning storm is preserved, but more commonly subsequent storms have scoured the tops of previous storm deposits resulting in an amalgamation of beds of HCS and SCS. The depositional environment is interpreted as a storm-dominated middle shoreface.

\section{Facies 11: Bioturbated medium-grained sandstone facies}

Facies 11 consists of sharp based, medium grained sandstone. It is characterized primarily by horizontal burrows but vertical burrows and tracks are preserved as well. Sedimentary structures have been obliterated by bioturbation. Traces of ?Macaronichnus dominates the trace fossil assemblage.

This facies is only preserved at the top of parasequence 14 in the Trevor Formation and is interpreted to represent preservation of part of the upper shoreface. In the other parasequences, wave-based erosion by transgression has removed the shallow marine facies, with the exception of lag deposits preserved on the top of several amalgamated sandstone bodies. The coarser grain size and heavy bioturbation suggests that this facies preserves part of the upper shoreface. 


\subsection{Lithology of the Hume River reference section}

Meterages given within descriptions of formations are a running total from the base of the Martin House Formation (see Figs. 7-10). The legend for stratigraphic logs is given in Figure 6.

\section{Martin House Formation}

In the study area the Martin House Formation unconformably overlies the Devonian Imperial Formation. The basal Cretaceous formation outcrops in a small tributary to the Hume River, is $13.5 \mathrm{~m}$ thick and is gradationally overlain by Arctic Red Formation (Fig. 7). Below the basal contact, Imperial Formation strata consist of greenish grey to rusty brown thin interbeds of mudrock and siltstone. The basal contact of Martin House Formation with Imperial Formation strata is sharp and undulatory.

The base of the Martin House Formation is a $15 \mathrm{~cm}$ thick pebbly sandstone bed (Facies 1). Poorly sorted, subrounded chert pebbles average $2 \mathrm{~cm}$ diameter, but can be as large as $5 \mathrm{~cm}$. This is overlain by $1.05 \mathrm{~m}$ of Facies 2 with intensely bioturbated medium grained sandstone. Skolithos and Chondrites ichnofossils characterize this interval. Within this interval is a $15 \mathrm{~cm}$ thick bed of pebbly sandstone. Bioturbation has obliterated all primary sedimentary structures. A semirecessive interval of Facies 5 from $1.05 \mathrm{~m}$ to $2.1 \mathrm{~m}$ consists of interstratified mudrock and siltstone characterized by vertical burrows of Rosselia and Skolithos. 
Overlying this is $1.45 \mathrm{~m}$ of alternating $10-20 \mathrm{~cm}$ beds of low-angle cross-stratified and bioturbated medium grained sandstone of Facies 2 . Within the bioturbated beds are horizontal and vertical burrows including Rosselia traces. This is overlain by 50 $\mathrm{cm}$ of dominantly mudrock with interbedded sandstone that characterize Facies 5 with bedding thickness of 1-5 cm. Concretions and Rosselia traces are present.

From $4.1 \mathrm{~m}$ to $7.45 \mathrm{~m}$ is an interval of Facies 2 characterized by sharp based finegrained sandstone with a basal horizon of Thalassinoides. Most of this interval is highly bioturbated with predominantly horizontal burrows $<2 \mathrm{~cm}$ in diameter. Within this interval a $20 \mathrm{~cm}$ bed of low-angle cross-stratified sandstone topped by ripple cross-laminated sandstone occurs, possibly recording waning storm energy from Facies 3. A $15 \mathrm{~cm}$ thick bed of HCS sandstone overlies this interval. A distinct $30 \mathrm{~cm}$ thick bed of fine-grained, bioturbated, concretionary sandstone occurs, which is easily traceable, and can possibly be correlated to other outcrops.

From $8.3 \mathrm{~m}$ to $8.7 \mathrm{~m}$ a $15 \mathrm{~cm}$ thick bed of fine-grained HCS sandstone is overlain by centimeter scale interbedded mudrock and fine grained sandstone. This is overlain by a $15 \mathrm{~cm}$ thick interval of low-angle cross-stratified sandstone overlain by a ripple topped bed of Facies 3. This interval is overlain by $1.4 \mathrm{~m}$ of fine grained semi-recessive bioturbated sandstone which grades into $3.45 \mathrm{~m}$ of interstratified fine grained sandstone and mudrock of Facies 5. Bedding thickness of sandstones decreases upwards from $20-5 \mathrm{~cm}$ to $10-1 \mathrm{~cm}$ thick beds as the interval fines into shales of the Arctic Red Formation. 


\section{SECTION LEGEND}
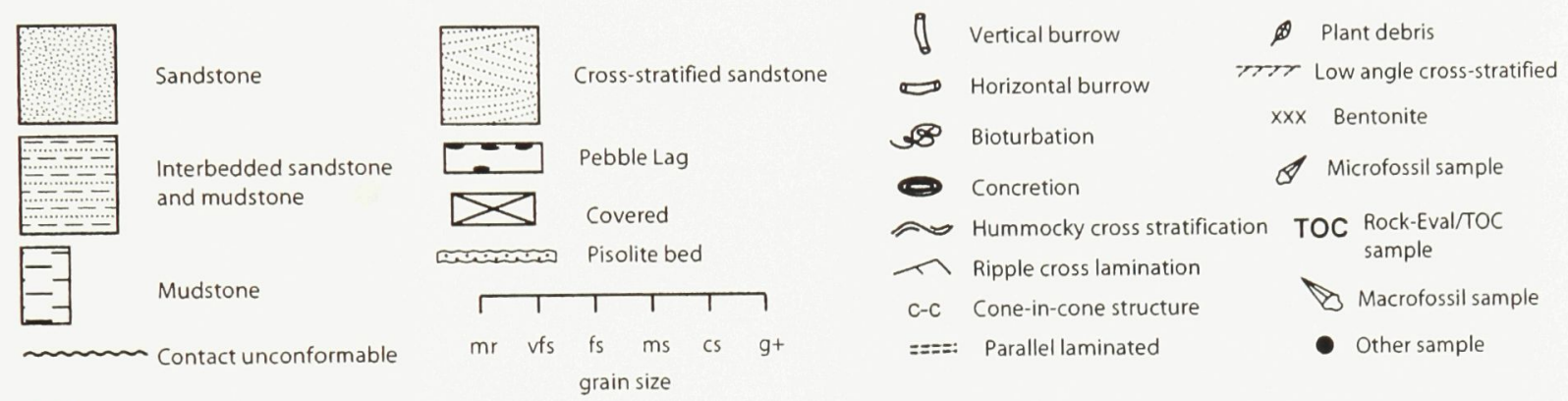

F1 facies

\section{grain size abbreviations}

$\begin{array}{lll}\text { mr-mudrock } & \text { fs - fine sand } & \text { cs - coarse sand } \\ \text { vfs - very fine sand } & \text { ms - medium sand } & g+\text { - granule and coarser }\end{array}$

Figure 6. Stratigraphic section legend. 

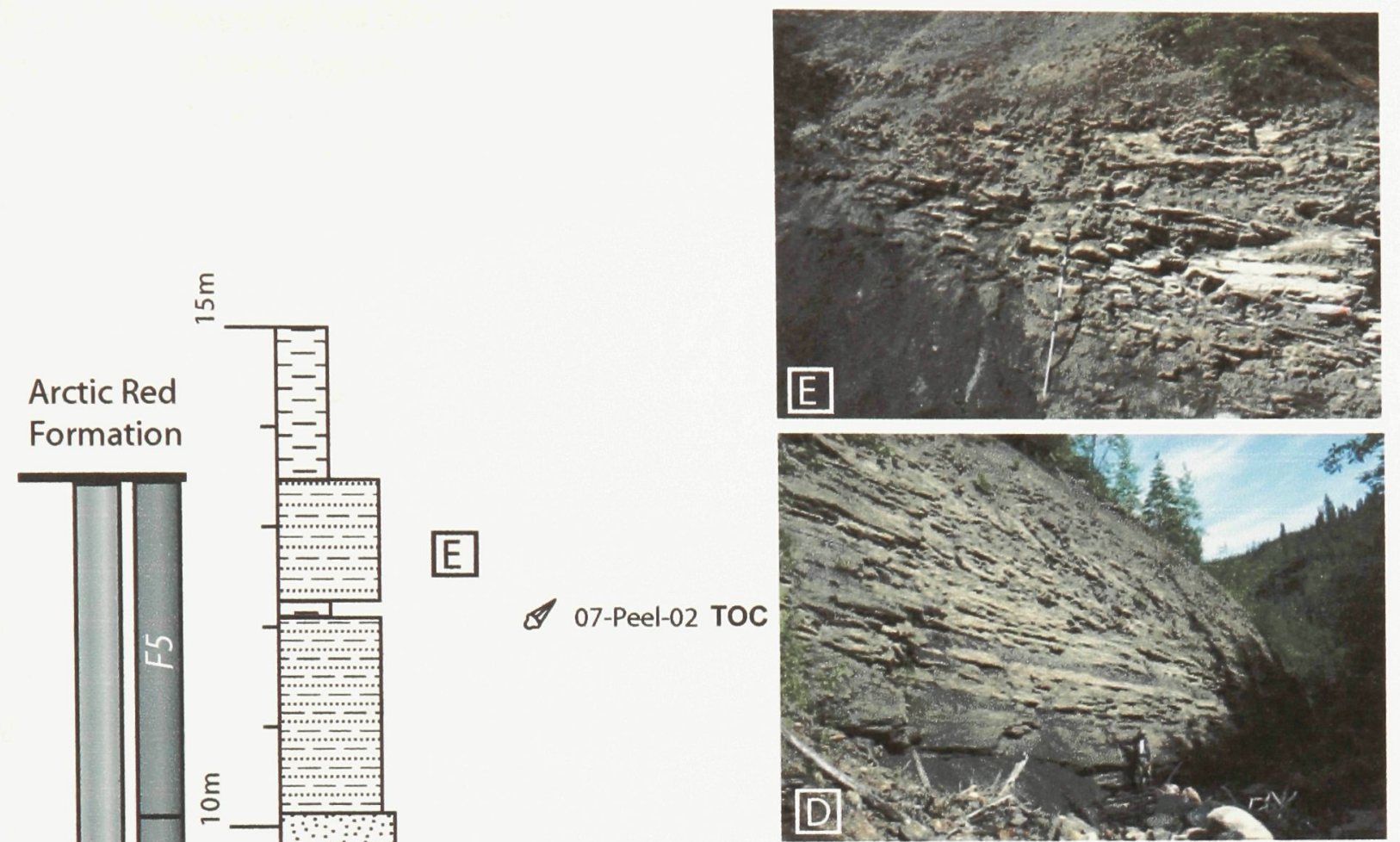

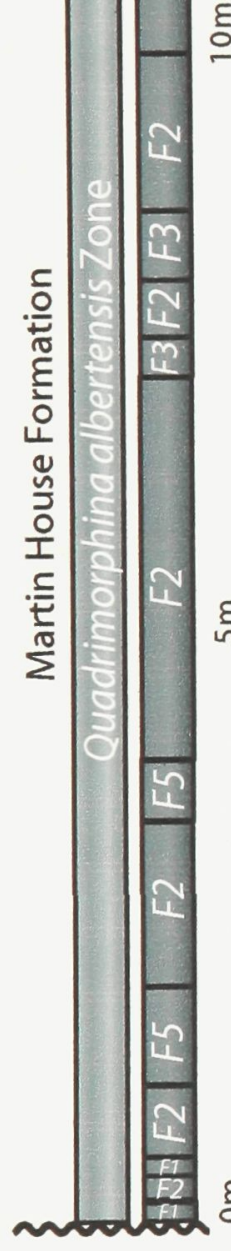

Imperial

Formation
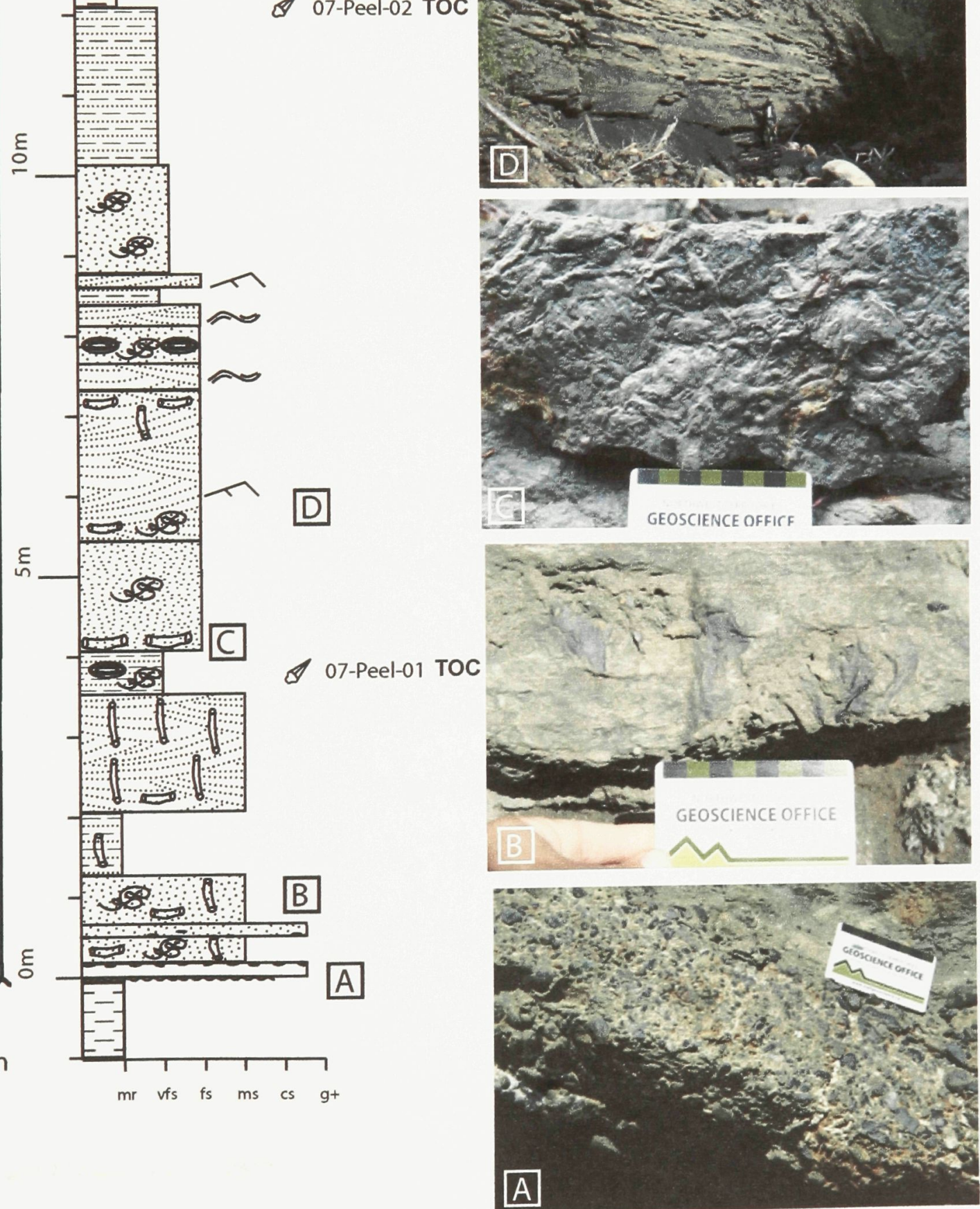

Figure 7. 
Figure 7. Measured section and outcrop photos of Martin House Formation. A.) Pebble sandstone lag and contact between Martin House Formation and underlying Devonian Imperial Formation. B.) Rosselia traces in sandstone. C.) Glossifungites surface. D.) Outcrop photo of interbedded sandstone and mudrock of Martin House Formation. E.) Upward fining gradation of sandstone into offshore mudrock.

\section{Arctic Red Formation}

Arctic Red Formation conformably overlies Martin House Formation and is disconformably overlain by Slater River Formation. In the study area it is $710 \mathrm{~m}$ thick (Fig. 8). The predominant lithology is mudrock common to Facies 4, although laminae and thin lenticular to continuous beds of siltstone and fine-grained sandstone are present, particularly near the top of the formation where sediment coarsens upwards to Facies 5. Sedimentary structures are uncommon.

The basal part of Arctic Red Formation from 14.1 to $543 \mathrm{~m}$ is dark grey to black, poorly indurated shale and mudrock of Facies 4 . There are rare cone-in-cone structures, vertical traces of Teichichnus and thin $(<1 \mathrm{~cm})$ bentonite beds.

Concretions ranging in size from several centimeters to tens of centimeters in diameter are common. They can be ellipsoidal to planar in geometry, and are random to concentrated along a bedding surface. Some concretions are found to have nucleated around shells of mollusks. Macrofossils include rare ammonites and pelecypods (?Inoceramus). In general the abundance and thickness of siltstone and sandstone beds increases up section, from 543 to $664 \mathrm{~m}$, to Facies 5, however the predominant lithology remains shale. Fine grained sandstone beds range from lenticular to continuous, dependant on the amount of sand size material available. 
Ripple cross-lamination is discernable within thin beds of sandstone. Traces include indeterminate horizontal burrows and escape structures that have been infilled with overlying sandstone. At $659 \mathrm{~m}$ there is a $15 \mathrm{~cm}$ bed of fine-grained sandstone with HCS.

A covered interval occurs from 664 to $721 \mathrm{~m}$. A pisoidal ironstone horizon, which distinguishes Facies 6, marks the top of Arctic Red Formation. This horizon is characterized by 5 to $20 \mathrm{~cm}$ thick beds of pisoidal ironstone that are interstratified with shale over an interval of approximately $1 \mathrm{~m}$. A wood fragment was found within a bed of pisoidal ironstone. In outcrop beds are resistant rusty dark brown grey with centimetric concentrically laminated pisoids, some of which react with dilute hydrochloric acid.

\section{Slater River Formation}

The Slater River Formation disconformably overlies the Arctic Red Formation (Hadlari et al., 2009). Its thickness to the base of the Trevor Formation is $392 \mathrm{~m}$ (Fig. 9). The pisoidal ironstone that marks the top of the Arctic Red Formation is overlain by approximately two meters of black shale with thin fine-grained sandstone interbeds and carbonaceous laminae of Facies 7. The interval from $733 \mathrm{~m}$ to $755 \mathrm{~m}$ is black, poorly indurated shale containing two centimeter thick bentonite beds and a few concretionary horizons. The bentonites occur at $740.5 \mathrm{~m}$ and $751.5 \mathrm{~m}$. At $755.7 \mathrm{~m}$ is a $10 \mathrm{~cm}$ thick bed of Facies 8 characterized by soft black shale with a high gamma value. The radioactive mudrock is overlain by $31 \mathrm{~m}$ of black shale of Facies 4 including nine millimeter thick bentonites, as well as common concretions. 

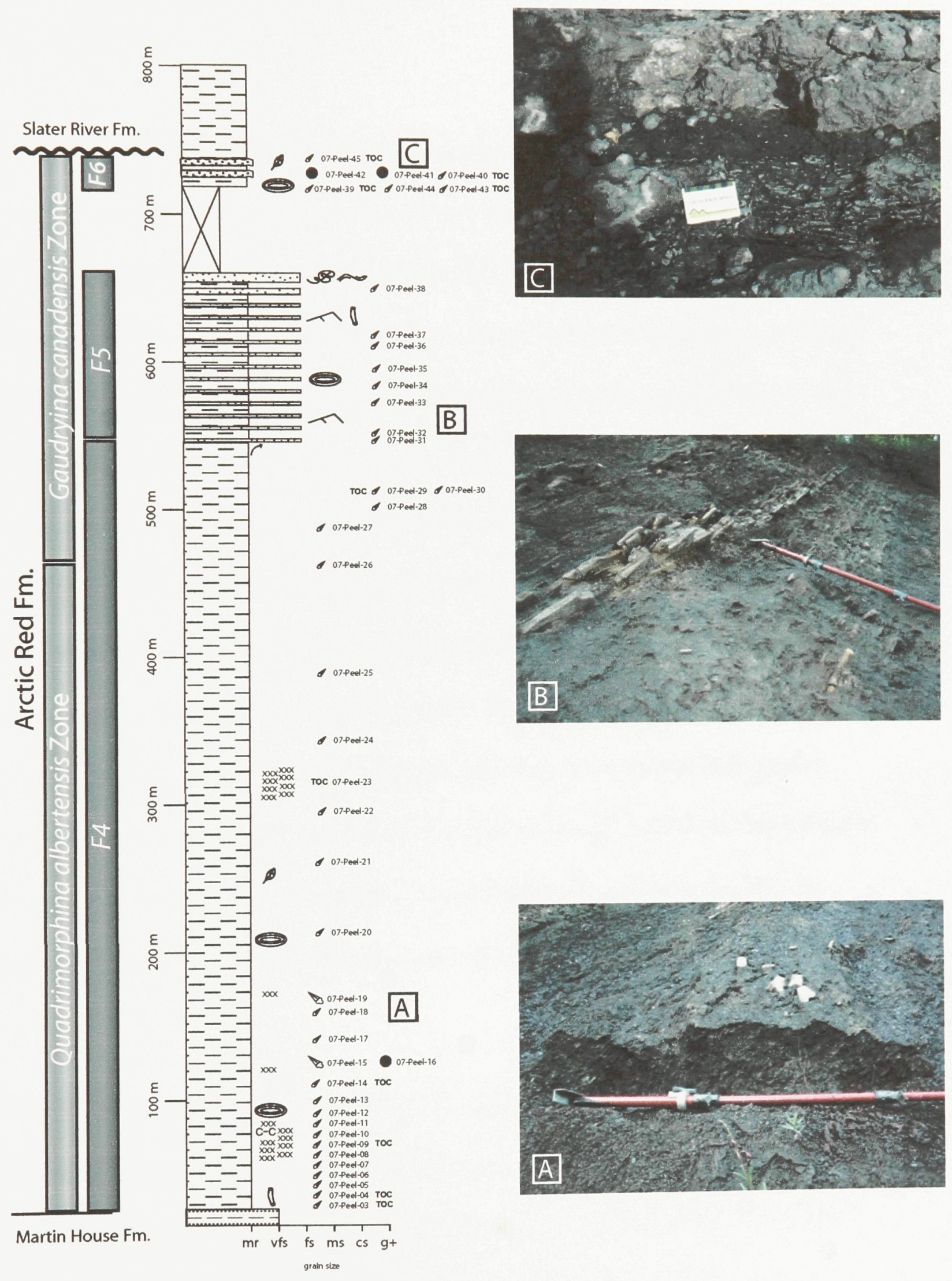

Figure 8. 
Figure 8. Measured section and outcrop photos from Arctic Red Formation. A.) Representative photo of black mudrock that characterizes Arctic Red Formation. B.) Fine-grained sandstone beds within mudrock. C.) Pisoidal ironstone underlain by shale.

The interval from $802 \mathrm{~m}$ to $859 \mathrm{~m}$ is coarsening upward, interbedded sandstone, siltstone, and mudrock of Facies 5. Siltstone beds are $1 \mathrm{~cm}$ thick and pinch and swell. Fine-grained sandstone beds range in size from 5-10 cm thick and are spaced 50$150 \mathrm{~cm}$ apart. This interval is overlain by $51 \mathrm{~m}$ of interstratified sandstone, siltstone, and shale where shale dominates. Fine-grained sandstone beds range in size from 5$10 \mathrm{~cm}$ thick and are spaced 50-150 cm apart. From $904 \mathrm{~m}$ to $951 \mathrm{~m}$ interbedded fine-grained sandstone, siltstone, and shale occur. Sandstone beds are 1-10 cm thick and spaced every 5-10 cm. Sedimentary structures include rare HCS, ripple crosslamination, and 2D and 3D ripples which can be seen on bedding surfaces. Some sandstone beds are lenticular; rare massive beds with mud rip-up clasts are also present. Flow direction is to the east indicated by crests of asymmetrical ripples. Pyrite rosettes have been observed. This interval is overlain by $21 \mathrm{~m}$ of rhythmically interbedded, coarsening upwards sandstone and shale spaced every $50-100 \mathrm{~cm}$. Sharp-based, cross-laminated sandstone beds thicken from $1-3 \mathrm{~cm}$ to up to $30 \mathrm{~cm}$ thick .

A covered interval of $53 \mathrm{~m}$ separates the previously described interval from the top $87 \mathrm{~m}$ of Slater River Formation, which consists of interbedded sandstone, siltstone, and shale. Shale to sandstone ratios alternate between shale dominance and sandstone dominance. At the base of this interval sandstone beds are thin, 


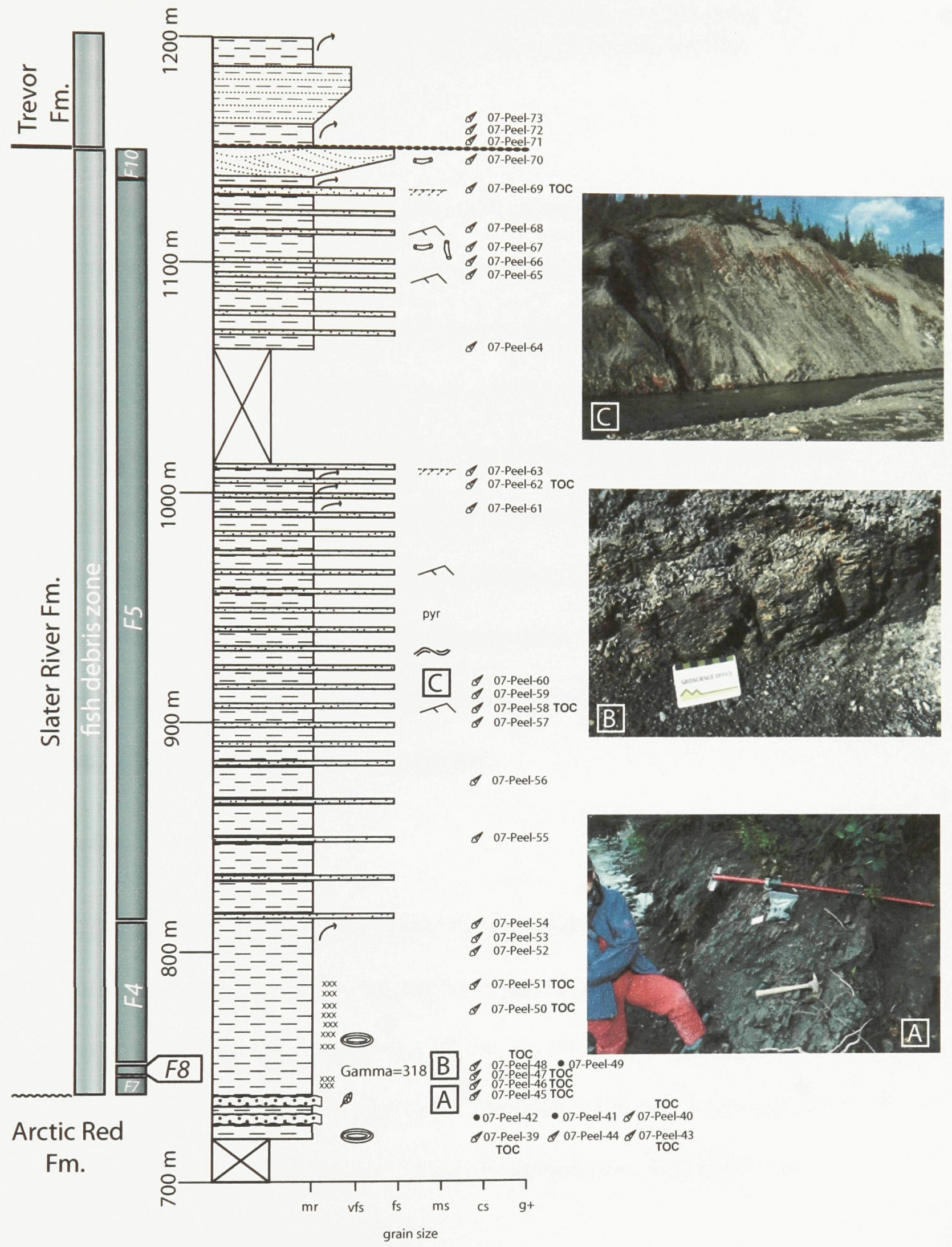

Figure 9. 
Figure 9. Measured section and outcrop photos of Slater River Formation. A.) Carbonaceous shale that overlies pisoidal ironstone. B.) High gamma shale. C.) Representative outcrop photo of rusty shale and thin sandstone beds that characterize Slater River Formation.

generally only $2-5 \mathrm{~cm}$ thick, and can be ripple cross-laminated. Sandstone beds thicken and increase in abundance up section. Low-angle cross-stratification, ripple cross-lamination, and rare vertical and horizontal burrows are present. A pebble bed preserved atop a meter thick amalgamated sandstone bed of facies 10 marks the top of this formation. In order to synchronize the lithostratigraphic framework with a sequence stratigraphic approach, this first pebble bed, interpreted as a transgressive lag is the boundary between Slater River and Trevor formations (Hadlari et el., 2009). Lithostratigraphically, the top of the Slater River Formation is put at the base of the first pebble bed of facies 1 of the prograding sandstone parasequences of the overlying Trevor Formation.

\section{Trevor Formation}

The uppermost formation in the Hume River is the Trevor Formation that is $720 \mathrm{~m}$ thick and consists of 21 shallowing upward parasequences (Fig. 10). Six facies are present in Trevor strata including F1, F4, F5, F9, F10 and F11.

Parasequences are upwards coarsening successions from mudrock to amalgamated sandstone. Due to the repetitive nature of these parasequences, description of Trevor Formation follows a facies approach. 
Parasequences are typically bound by flooding surfaces and consist of a facies succession from mudrock facies to amalgamated sandstone facies, with the exception of parasequence 14 which preserves part of the upper shoreface with bioturbated medium grained sandstone facies (Fig. 11). Sandstone bodies are commonly topped by coarser-grained lag deposits (Fig. 10). Typically, offshore mudrock facies is 20 to 60 meters thick, transitional facies from interstratified shale, siltstone, and cross-laminated fine-grained sandstone facies to interbedded sandstone and mudrock with HCS facies is 5 to 20 meters thick, and middle shoreface amalgamated sandstone sheets are 2 to 10 meters thick.

\subsection{Gamma Ray Logs}

Gamma ray values were measured in outcrop along the Hume River section for comparison with subsurface well log data, in particular with the reference well Arctic Red F-47 (Figs. 2, 12). It is noted that the resolution of outcrop measurements is reduced compared to subsurface well logs due to the time-consuming process of digging for fresh continued outcrop surfaces and covered sections. The contact between Martin House and Arctic Red formations is easily identifiable on gamma logs as a sharp increase in response to the transition from sandstone to mudrock lithologies. The gamma kick within the basal Slater River Formation, interpreted as a condensed section, is a valuable marker because of its ease to pick and proximity to the pisoidal ironstone forming the boundary between the Arctic Red and Slater River formations. The high gamma shale occurs $20 \mathrm{~m}$ above the paleosol. This 


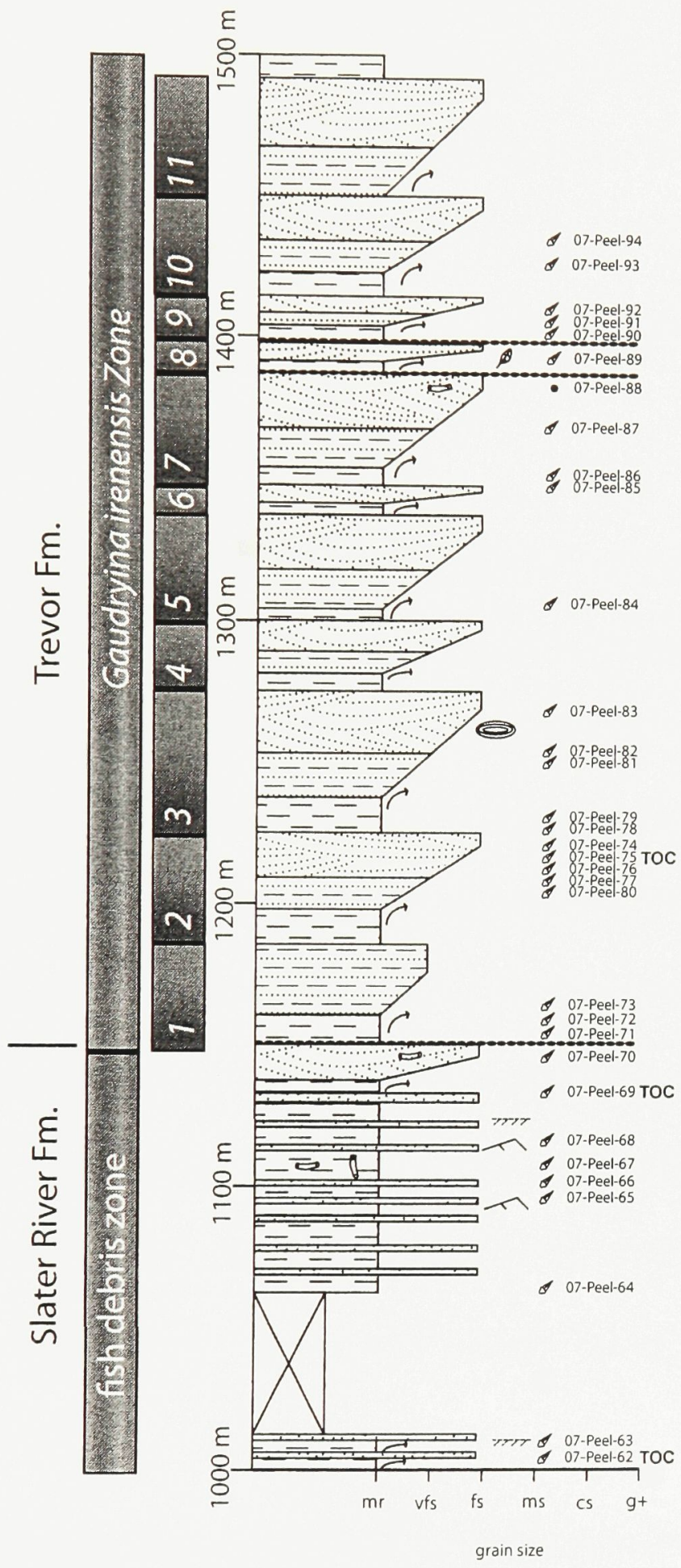

Trevor Formation

Hume River Section

Parasequence
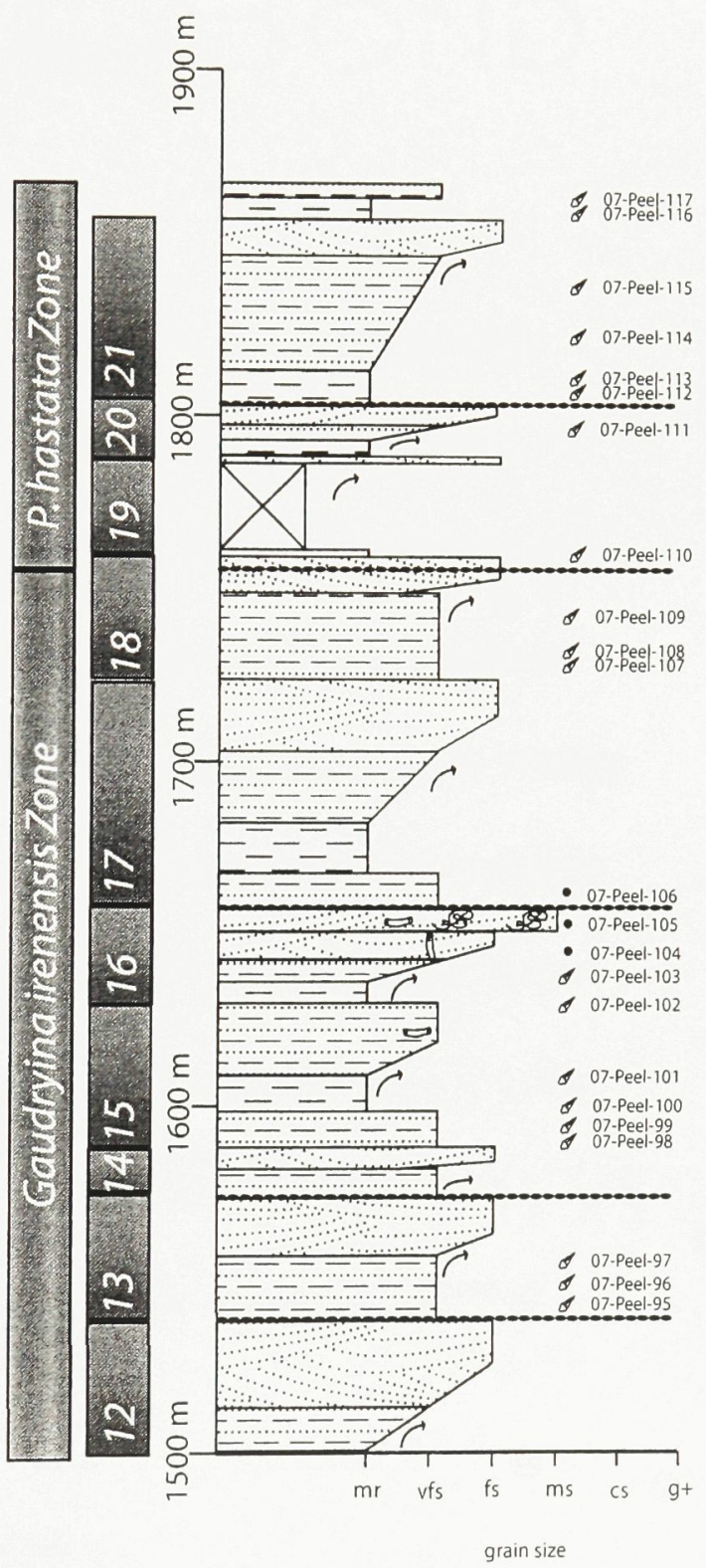

Figure 10. Measured section of Trevor Formation from Hume River with 21 upwards coarsening parasequences. 
marker ties outcrop data to subsurface and allows for easy correlation to other wells in the area (Hadlari et al., 2009) (Fig. 13). It represents the peak of a rapid transgression above the paleosol and switch to highstand systems tract, where sediment input to the system is minimal. Upward coarsening parasequences within Trevor Formation show classic response in gamma signatures.

\subsection{Rock-Eval/Pyrolysis Data}

Shale samples from each formation were analyzed and HI/OI (Hydrogen Index/Oxygen Index) values are compared (Table 2). Martin House Formation samples fall within the range of type III kerogen, terrestrial input is consistent with the interpretation of predominantly shallow marine facies. Arctic Red Formation samples plot along type II and III trends. Slater River Formation samples are mainly type I/II, with the exception of one outlier that falls in the range of type III kerogen, with very high OI index (Fig. 14). This sample was taken from carbonaceous shale directly overlying the pisoidal ironstone, supporting an interpretation of marginal marine-terrestrial environment. The Trevor Formation contains a mixed type II and III kerogen, however low $\mathrm{HI}$ and OI values do not allow for strong correlation to either trend.

\subsection{Petrology and Geochemistry, Pisoidal Ironstone}

The pisoidal ironstone (sample 07-Peel-41) beds occur at the stratigraphic interval that marks the disconformable boundary between the Arctic Red and Slater River formations. These resistant beds are underlain by grey shale of the Arctic Red 
Trevor Formation

Parasequence succession example
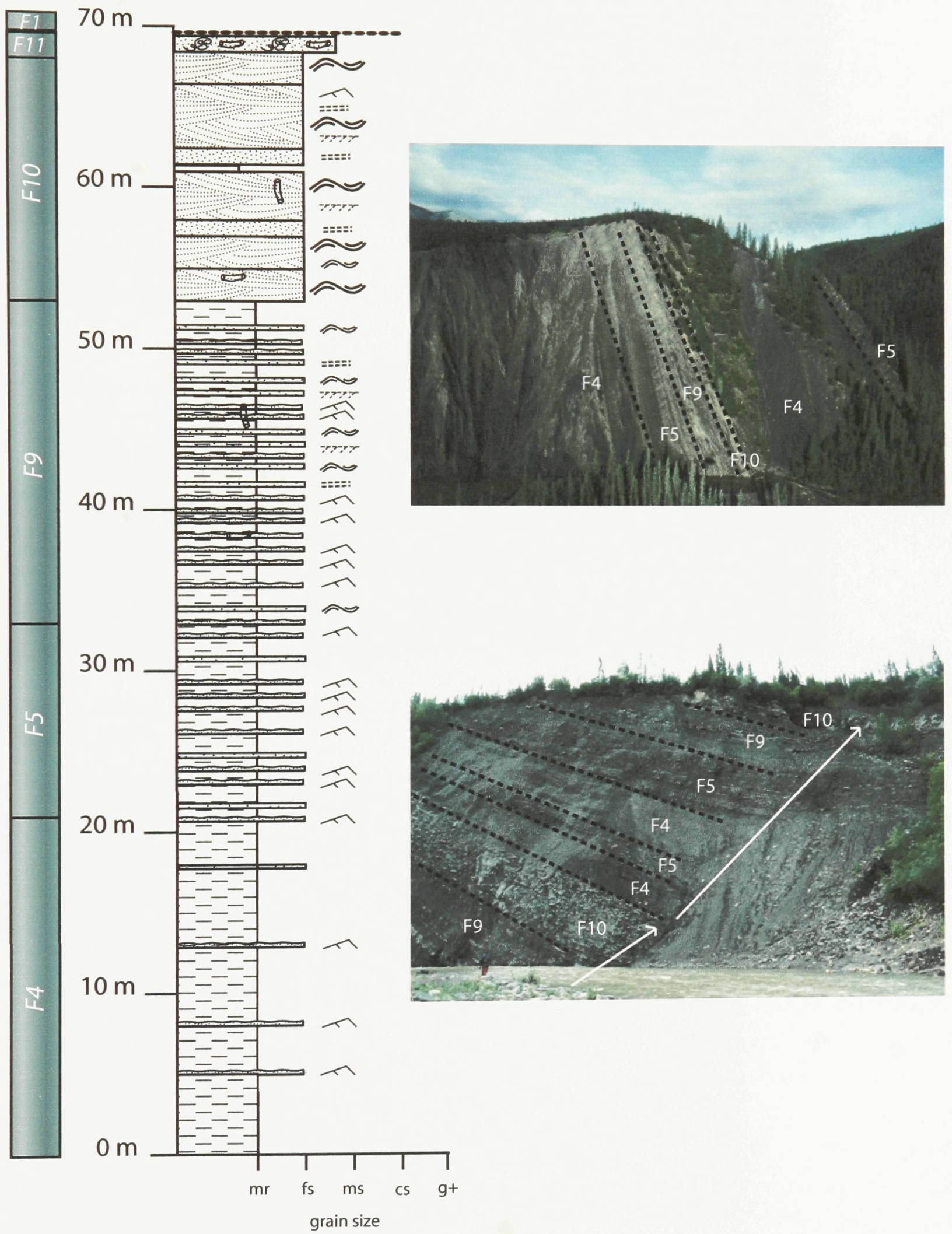

Figure 11. 

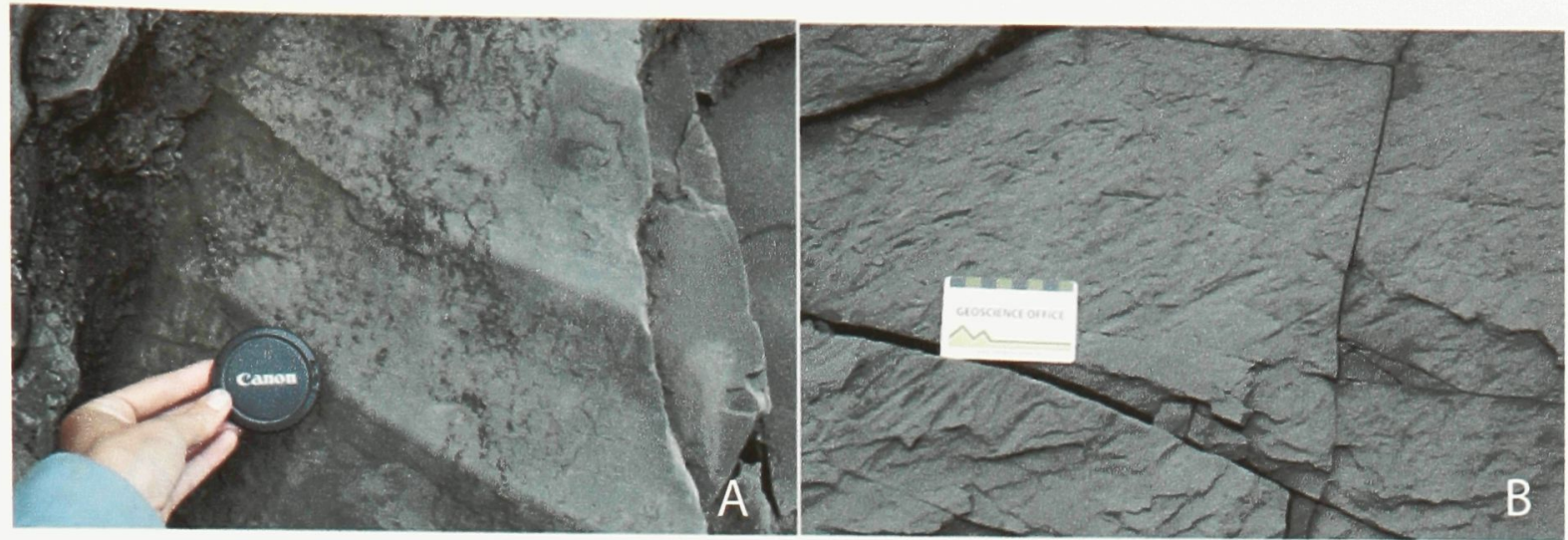

A. Symmetrical ripples in F9 of Trevor Formation. B. Scours on the top of fine-grained sandstone in F10.

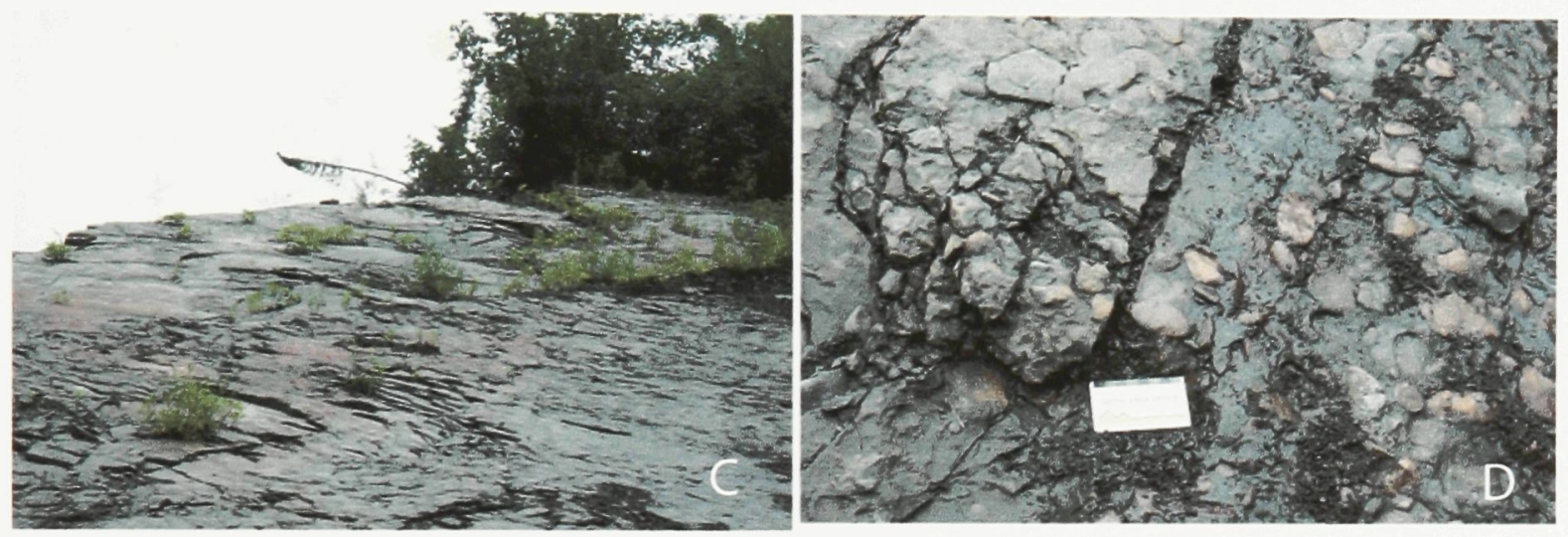

C. HCS in plan view from F10. Wave-length is approximately 1.5 meters. D. Pebble lag on top of an amalgamated sandstone bed.

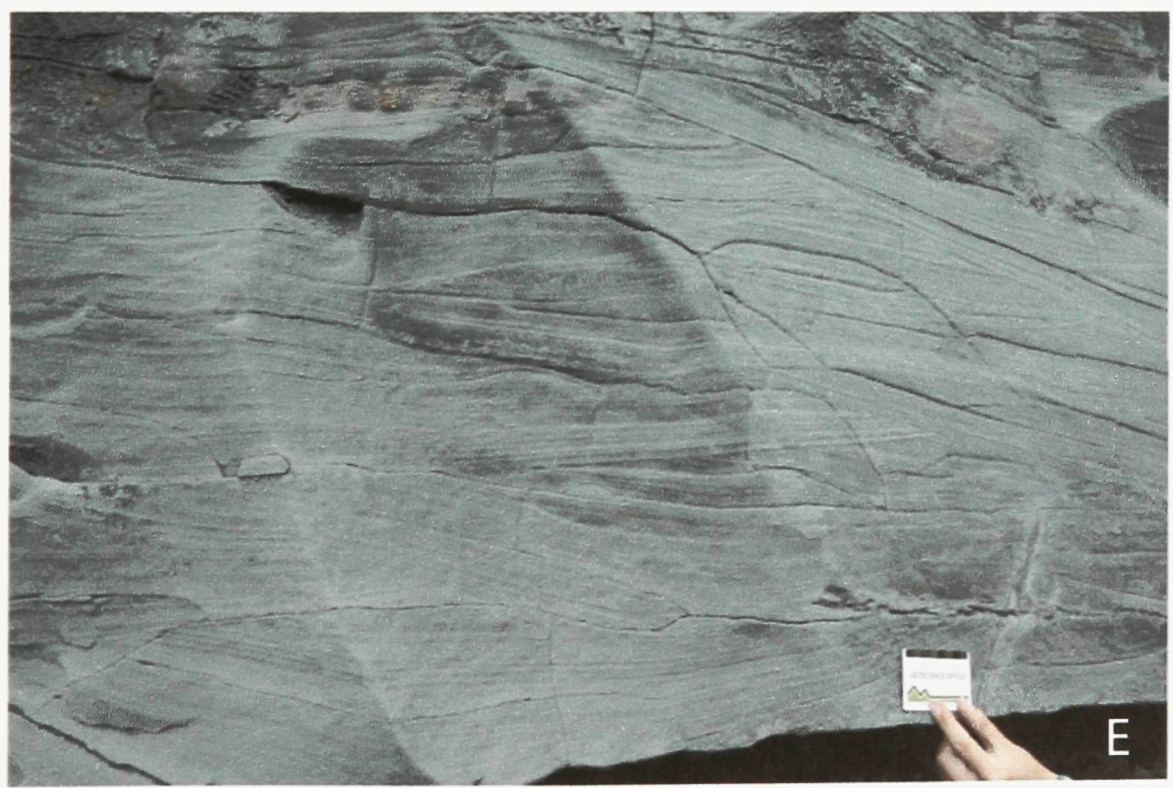

E. Amalgamated beds of HCS and SCS in fine-grained sandstone in F10.

Figure 12 . 


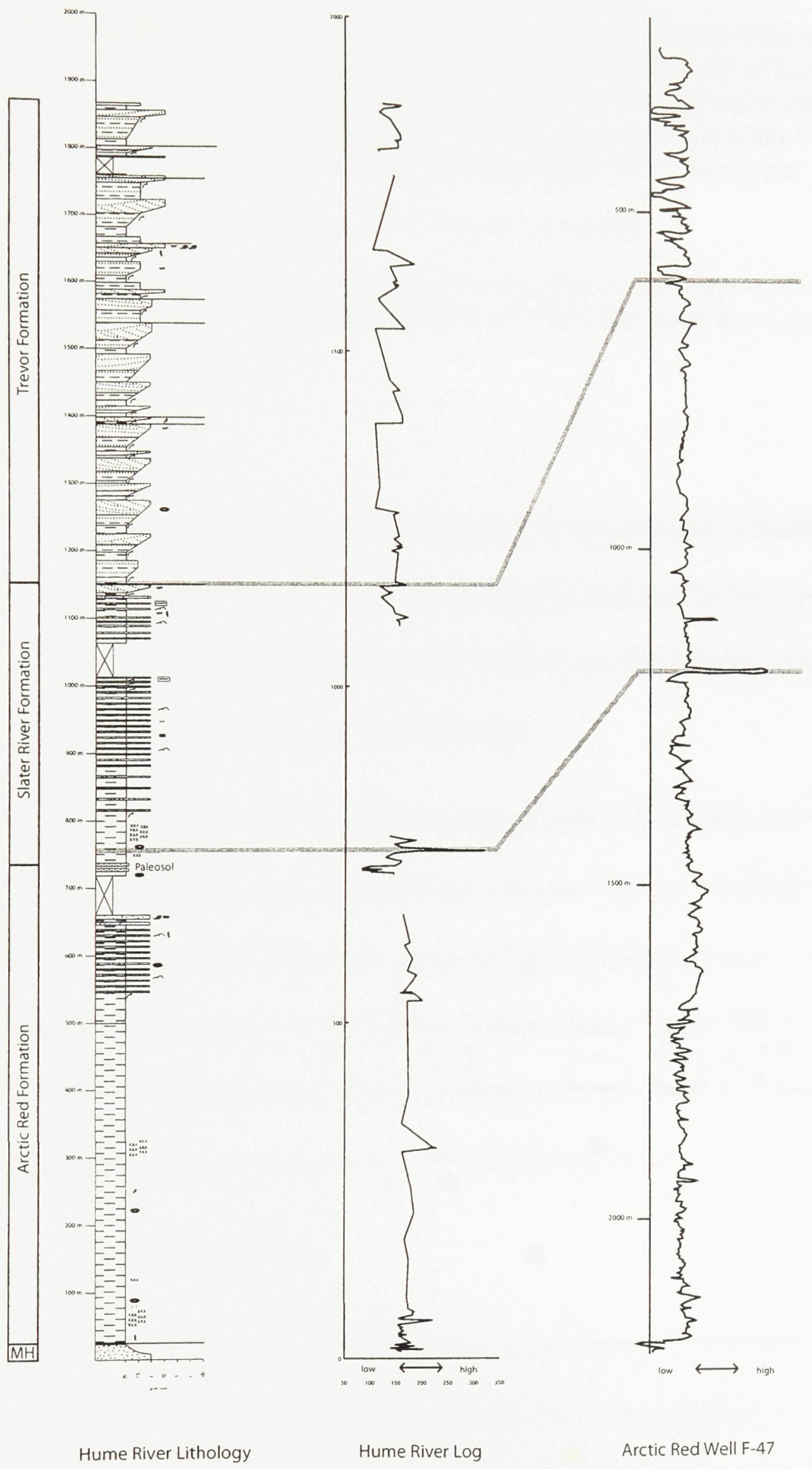

Figure 13. 
Figure 11. Example of a typical parasequence from Trevor Formation with representative outcrop photos. Top photo shows classic example of facies succession from mudrock facies up through amalgamated sandstone. Bottom photo shows an example of a parasequence that initially fines upward from flooding surface and then subsequently coarsens up to amalgamated sandstone.

Figure 12. Representative photos from Trevor Formation.

Figure 13. Hume River lithologic log, gamma log measured from outcrop, and gamma log from reference well Arctic Red F-47. Note the signature log marker located just above the paleosol.

Formation and overlain by mudstone, thin sandstone beds and carbonaceous

laminae of the Slater River Formation. Petrographic and geochemical studies were undertaken to give insight on the formation and diagenetic history of this unusual rock in order to put it into stratigraphic context.

Ooidal ironstones are classified as having $>5 \%$ vol. $\%$ ooids (in this case, pisoids, which are concentrically laminated particles $>2 \mathrm{~mm}$ in diameter) and $>15$ wt. \% iron (Young, 1989). Generally, ooids and groundmass consist of chamositic clay which is often replaced by carbonate (Mücke and Farshad, 2005). Apatite is a common additional component, but does not occur in the form of visual grains and can only be detected by high $\mathrm{CaO}$ and $\mathrm{P}_{2} \mathrm{O}_{5}$ in analyses (Mücke and Farshad, 2005).

\section{Petrology and Micromorphology}

In hand sample the weathered colour is a greenish to rusty dark grey (Fig.

15). Fresh colour of the matrix is dark brown to black, and pisoids range from dark brown to pale green as a factor of the extent of siderite replacement for chamosite. Siderite makes up the majority compositionally, which results in a dense and hard 
rock. Millimeter fractures are common and have been infilled by late stage blocky calcite cement. Using Dunham-style nomenclature (Young, 1989), this rock is a pisoidal float-ironstone with a siderite wacke-ironstone matrix.

The ironstone is composed of approximately $70 \%$ pisoids floating in a mud matrix. Allochems within the matrix are authigenic glaucony infilling pore space, acicular crystals replaced by siderite, trace sphaerosiderite, and trace detrital quartz grains (Fig. 16). Authigenic glaucony comprises approximately five percent of the total rock and is found as a late-stage clay mineral infilling pore space. Glaucony is rimmed by precursor sparry carbonate cement. Within the matrix are clusters of precipitated crystals of unknown original mineralogy with an acicular crystal habit that have since been completely replaced by siderite. Trace sphaerosiderite nodules are characterized by a micritic core, radial crystalline structure, and pseudo-uniaxial extinction pattern (Fig. 16).

Pisoids are 0.5 to $1 \mathrm{~cm}$ in diameter and spherical to ellipsoid in shape. They are generally solitary but may have grown together to form composite grains. Grain size decreases from core to rim. Rims have a cauliflower-like morphology and a diffuse contact with the surrounding mud matrix (Fig. 16). Pisoids have been replaced first by a clay mixture and then by multi-generational siderite. The clay is pseudo-isotropic in cross-polarized light (XPL). Under high magnification, very finegrained intergrowths of chamosite and apatite are present giving a felted texture 
Table 2. Rock-Eval data from Hume River section.

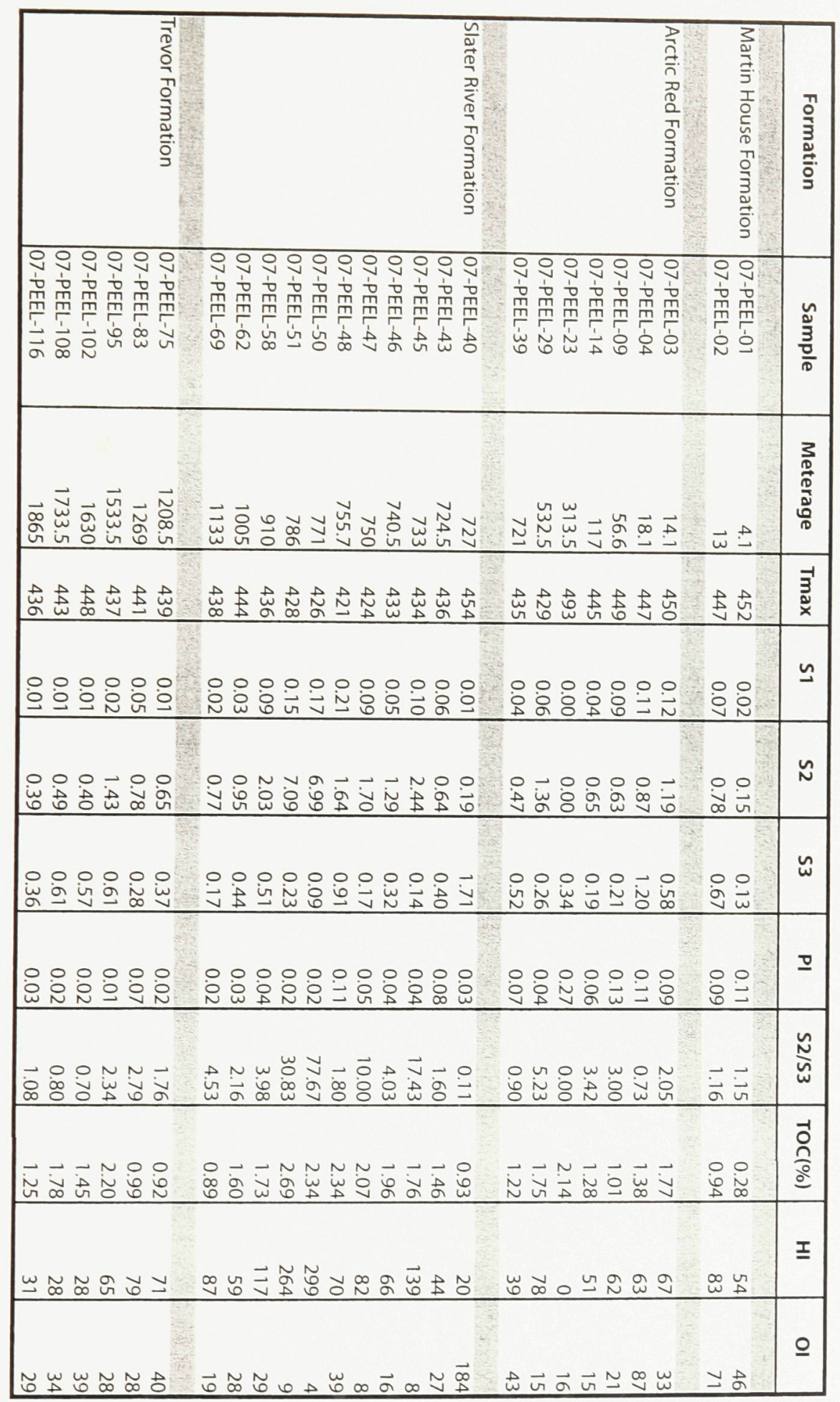




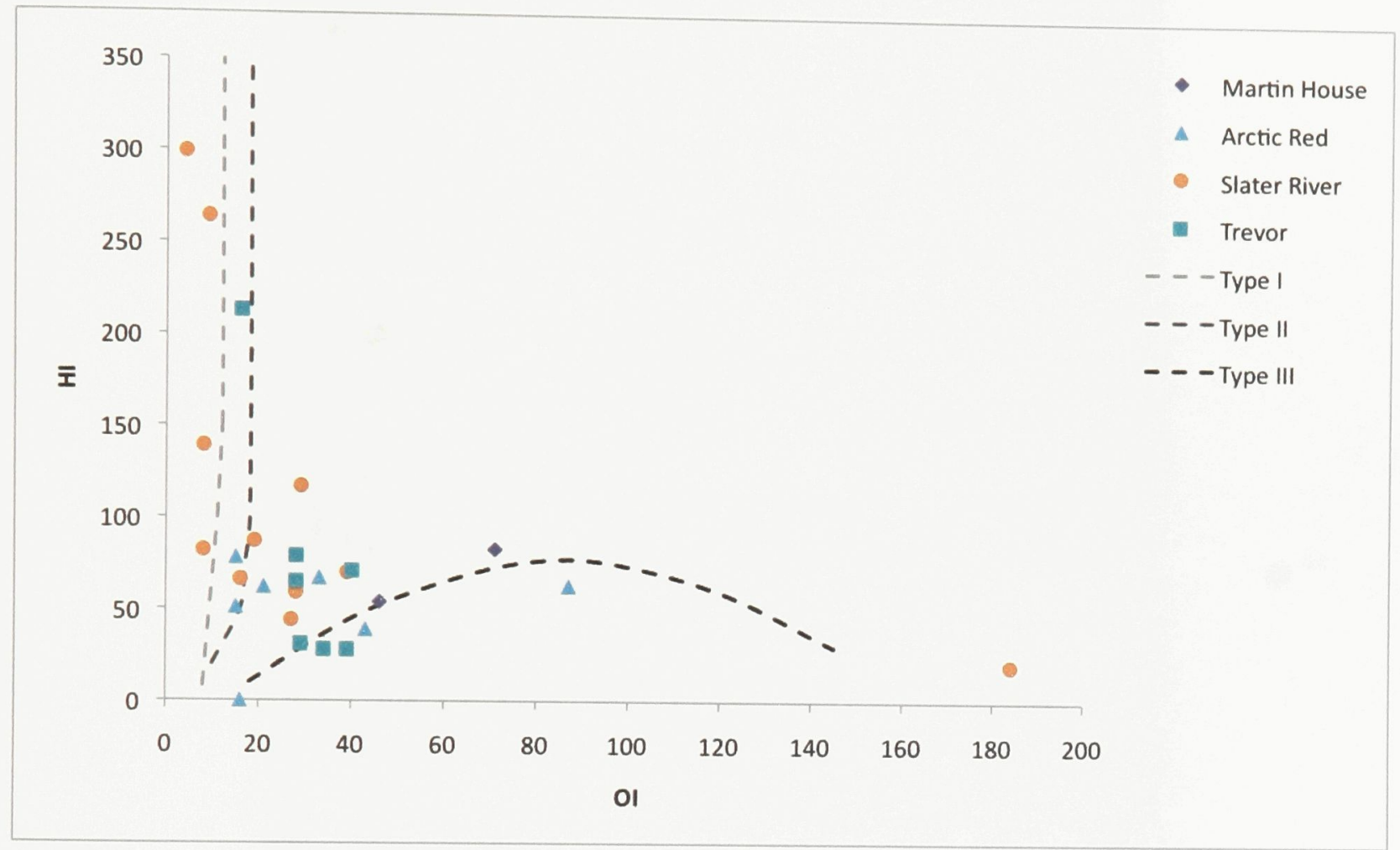

Figure 14. HI vs. OI plot of sample data from Hume River section. 

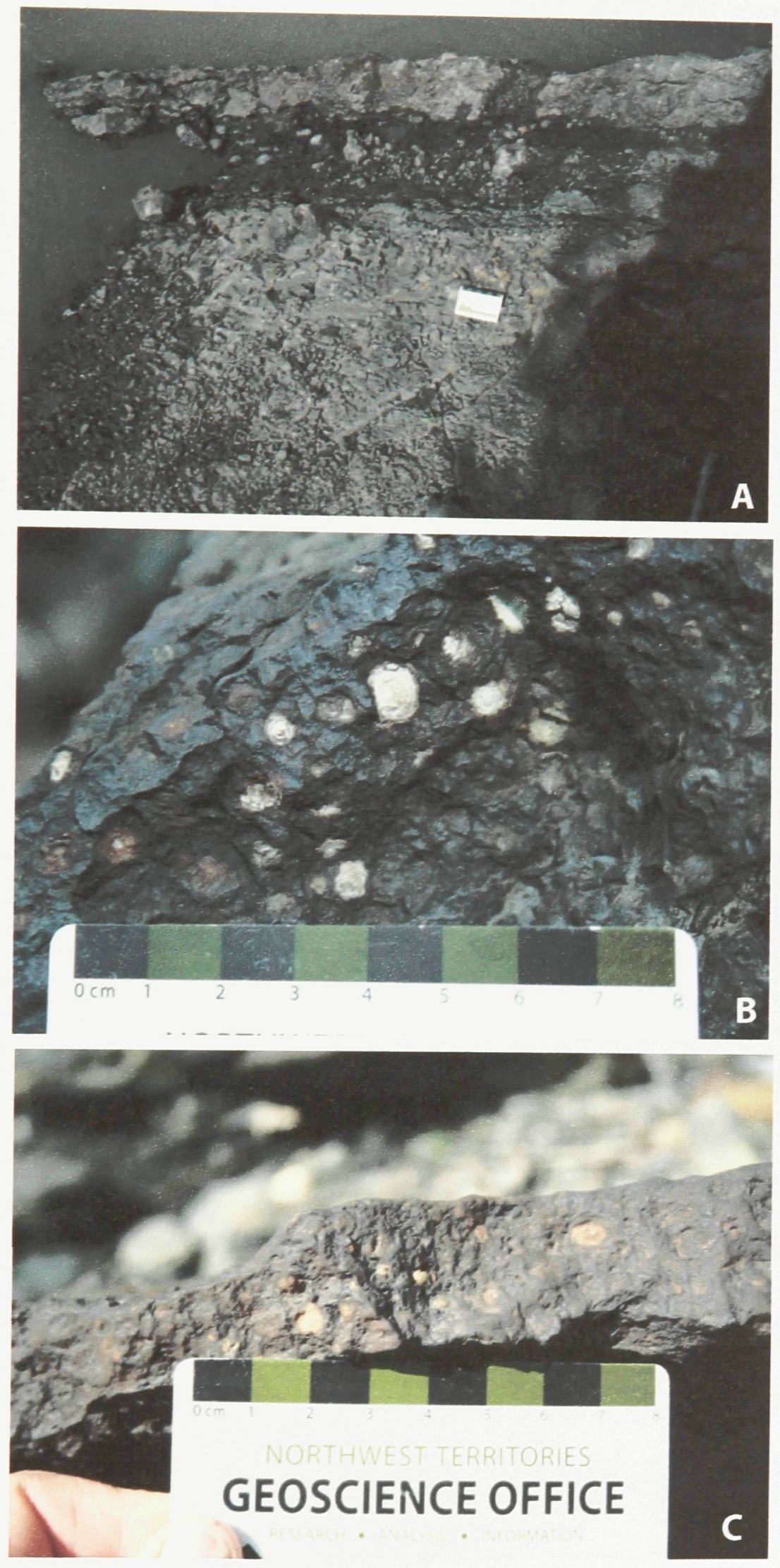

Figure 15. Outcrop photos of pisoidal ironstone. A. Pisoidal ironstone interbedded with grey shale. B. Close-up pisoidal ironstone. Note concentrically laminated pisoids approximately $0.5 \mathrm{~cm}$ wide. C. Bed of pisoidal ironstone, approximately $3 \mathrm{~cm}$ thick. 
to the clay. Due to the extremely fine-grained nature, mineral identification was confirmed by XRD and EPMA.

There are at least three generations of carbonate within the whole rock: 1) minor rhodochrosite with a bead-like habit at the cores of siderite crystals (not visible in regular optical petrography), 2) sparry siderite cement, 3) micritic siderite cement. Siderite appears to poke up through the clay because of its high relief relative to the clay. Siderite laminae of the pisoids are discontinuous indicating partial replacement. Pisoids may be fractured, and fractures are subsequently infilled with third generation micritic siderite cement.

XRD analysis

The thin section analyzed contained both pisoids and matrix and gave a diffraction pattern that matches siderite with the first seven peaks at 2.79, 3.59, $2.35,2.14,1.74,1.73$, and $1.96 \AA$ (Fig. 17). Minor peaks at 1.51 and $3.32 \AA$ are identified as glaucony. Shoulders to the left of the siderite peaks are recognized as rhodochrosite with peaks at $2.88,3.71$, and $1.53 \AA$. Chamosite and berthierine have the same chemical composition, chamosite belongs to the chlorite group and berthierine to the serpentine group; these clays can only be distinguished by XRD (Mücke and Farshad, 2005). Analysis confirms that a clay peak at $7.09 \AA$ is 

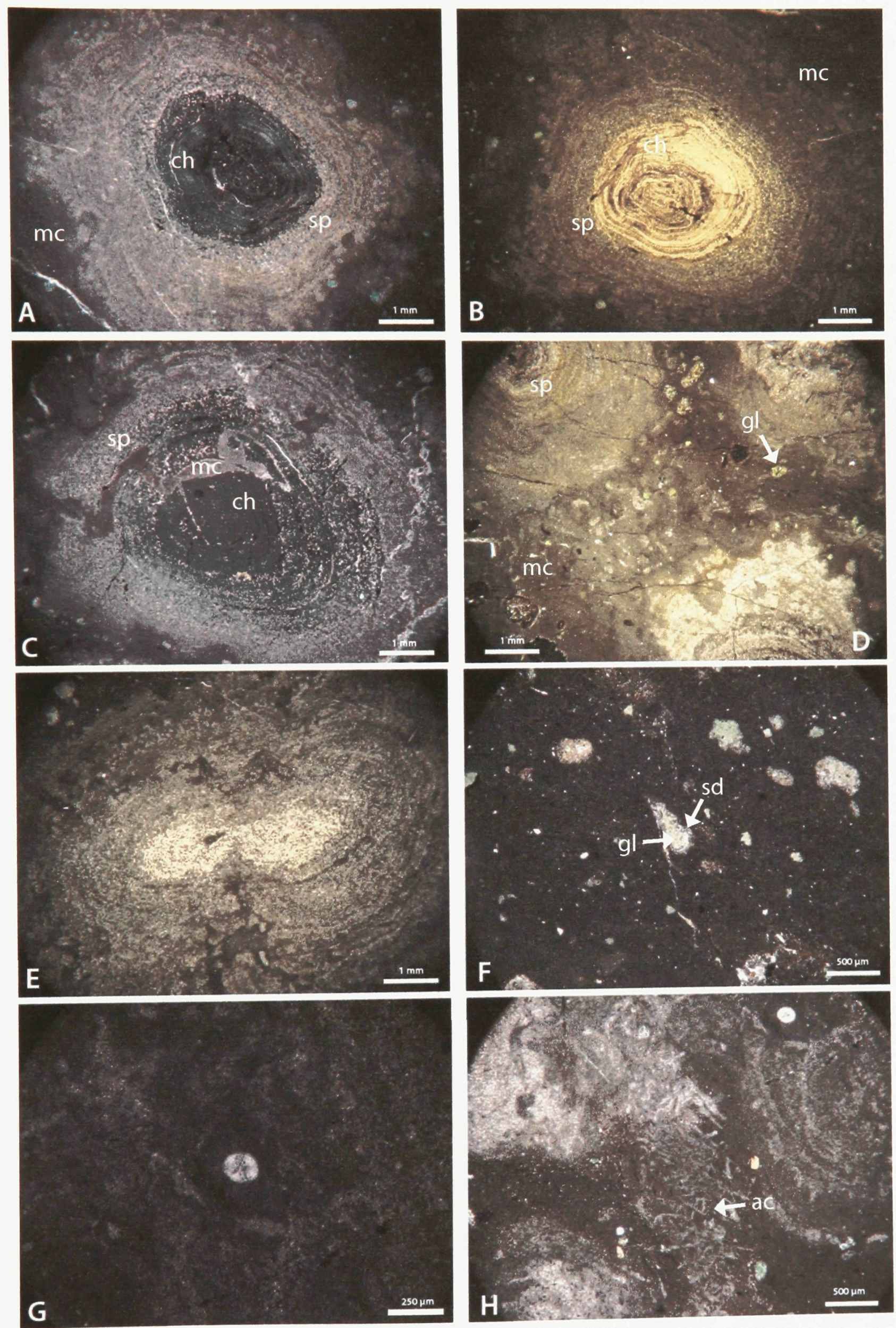

Figure 16. 
Figure 16. A.) Pisoid that has only been partially replaced by siderite. Core of the pisoid is pseudo-isotropic chamosite-apatite clay mixture (ch), rimmed by sparry siderite cement (sp). Groundmass is micritic siderite cement (mc). Glaucony is also visible in the lower right corner. Cross-polarized light (XPL). B.) Same as A, in planepolarized light (PPL). C.) Fracture cross-cutting a pisoid that is primarily composed of chamositic clay. Fracture is infilled with late stage micritic siderite cement. XPL. D.) Glaucony ( $\mathrm{gl}$ ) infilling pore spaces within the matrix of the pisoidal ironstone. Cauliflower texture on the rim of a pisoid is well developed in lower right corner, and the interfingering of sparry and micritic siderite can be seen along the rim. PPL. E.) Two pisoids that have grown together to form one compound pisoid that has been completely replaced by siderite. PPL. F.) Close up of glaucony that is rimmed by siderite (sd). PPL. G.) Sphaerosiderite nodule characterized by a micritic core, radial crystalline structure, and pseudo-uniaxial extinction pattern. XPL. H.) Needle mash of ascicular crystals (ac) within groundmass of pisoidal ironstone. Sphaerosiderite nodule in upper right corner. PPL.

chamosite. Apatite has a minor peak at $2.69 \AA$. There is most likely a chamosite and an apatite peak masked by the primary peak for siderite. A powder sample from the core of a pisoid with little siderite replacement was run to get a cleaner diffraction pattern for the clay (Fig. 17). The result had peaks that matched chamosite and apatite.

EPMA and backscatter imaging

When viewed with backscatter imaging the carbonate cement that makes up the majority of the rock shows two distinct phases. The predominant chemical phase is siderite, which encases a minor rhodochrosite antecedent phase. The rhodochrosite is distributed in a spotty pattern and shows up darker in backscatter images compared to the surrounding siderite due to decreased iron in the chemical composition (Fig. 18). FeO weight percents (wt. \%) of siderite range from 34.79- 

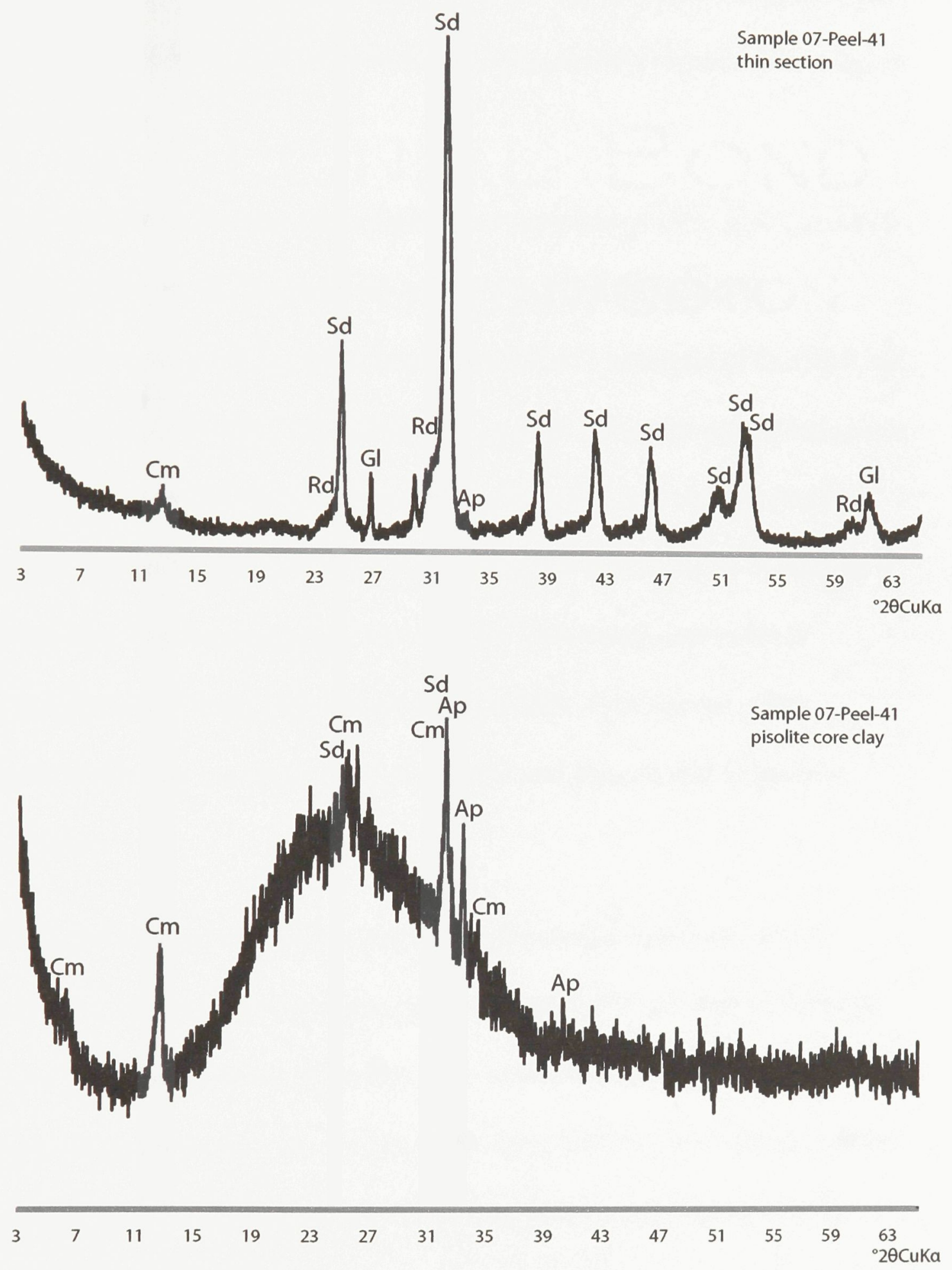

Figure 17. XRD analysis of thin section (top) and apatite-chamosite clay mixture (bottom) 
44.70\%. Rhodochrosite is low in Fe and high in $\mathrm{Mn}$ and $\mathrm{Ca}$, with minor $\mathrm{Mg}$. MnO wt. \% ranges from 33.39-38.95\%, CaO from $13.85-20.24 \%$, and $\mathrm{FeO}$ from $2.53-5.67 \%$ in rhodochrosite (Table 3).

Chemical data from the clay show significant amounts of $\mathrm{SiO}_{2}, \mathrm{Al}_{2} \mathrm{O}_{3}$, and $\mathrm{FeO}$ in the clay; $15.03-23.74$ wt. $\%, 10.73-16.98$ wt. $\%$, and 15.95-26.03 wt. \% respectively. However, all areas sampled have considerable amounts of Ca and P, wt. $\%$ 8.66-24.50\% CaO, 6.63-18.01\% $\mathrm{P}_{2} \mathrm{O}_{5}$ (Table 4), as well. While the abundance of $\mathrm{Ca}$ and $\mathrm{P}$ varies depending on the area analyzed, the ratio of the two cations remains consistent. This is approximately the same ratio of $\mathrm{Ca}$ to $\mathrm{P}$ that is found in apatite. If you disregard $\mathrm{Ca}$ and $\mathrm{P}$ in the analysis of the clay, the chemistry now reflects chamosite or berthierine. Chamosite is confirmed by XRD. This supports the interpretation that the clay is a mixture of chamosite and apatite that originally replaced the pisoids.

Amorosi's (1995) classification scheme for glauconitic minerals defines minerals with $<4$ wt. $\% \mathrm{~K}_{2} \mathrm{O}$ as nascent glaucony, 4-6 wt. $\% \mathrm{~K}_{2} \mathrm{O}$ as slightly evolved glaucony, 6-8 wt. $\% \mathrm{~K}_{2} \mathrm{O}$ as evolved glaucony, and $>8$ wt. $\% \mathrm{~K}_{2} \mathrm{O}$ as glauconitic mica. Glaucony in this sample have $\mathrm{K}_{2} \mathrm{O}$ wt. \% that range from 5.80-6.16\%, falling into the category of slightly evolved to evolved glaucony. The glaucony is high in $\mathrm{Al}$, with 12.77-13.98 wt. $\% \mathrm{Al}_{2} \mathrm{O}_{3}$ (Table 4). 

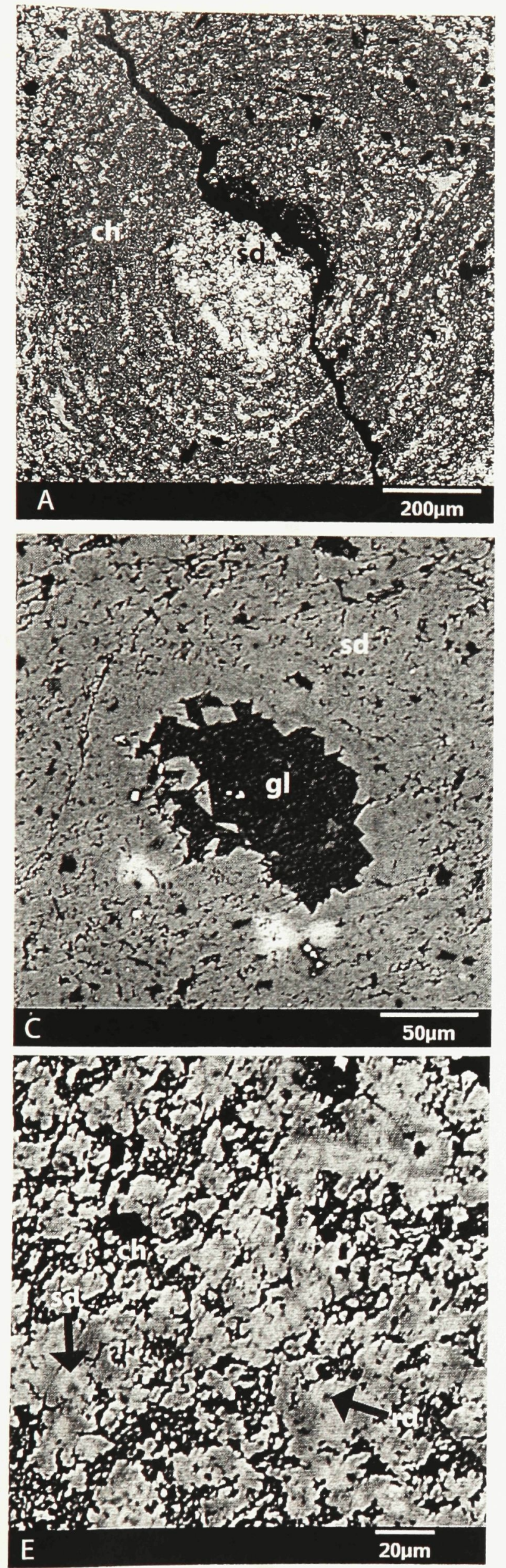
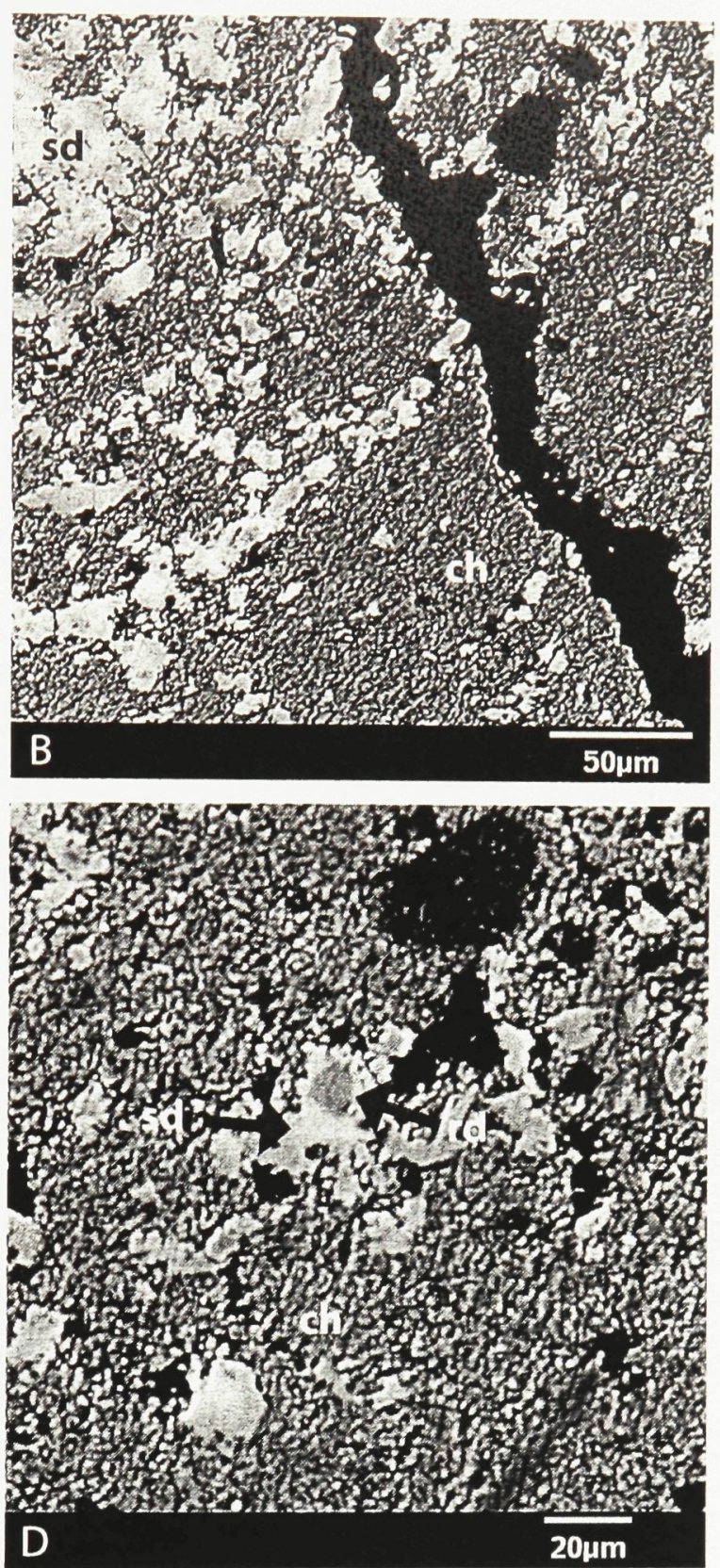

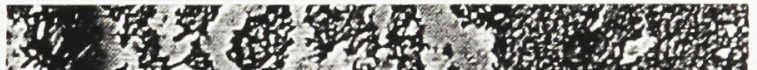

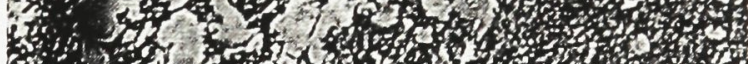

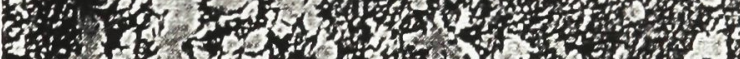

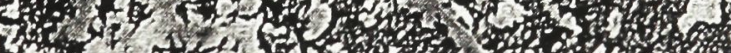

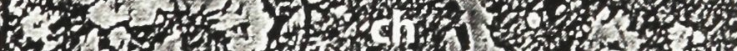

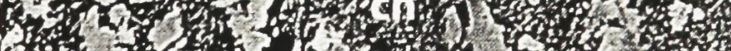

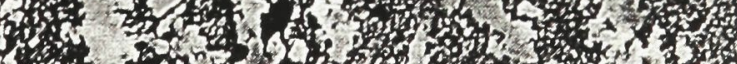

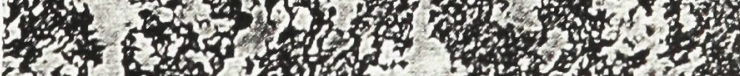

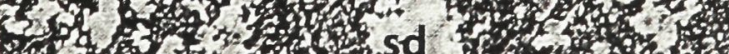

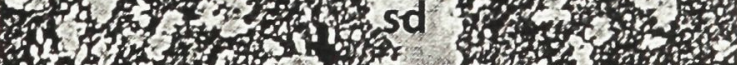

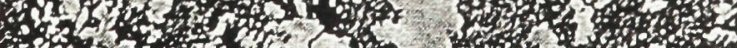

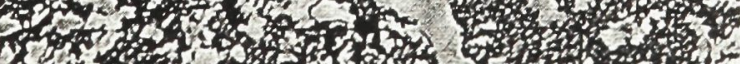

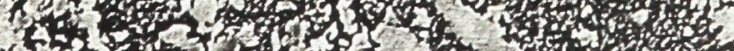

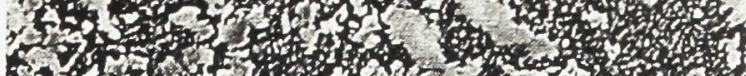

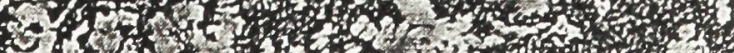

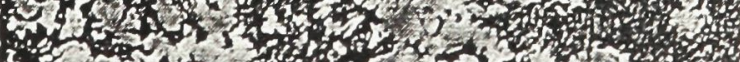

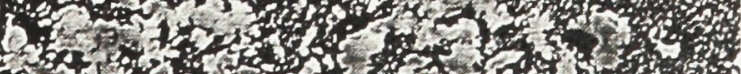
7.

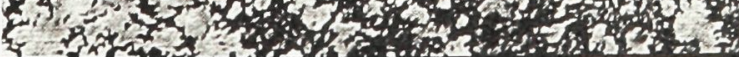

Figure 18. 
Figure 18. Backscatter images of sample 07-Peel-41 polished thin section. A.) Pisoid with sparry siderite cement (sd) replacing laminae of chamosite-apatite clay mixture (ch). B.) Close-up of laminae of pisoid. C.) Glaucony (gl) clay that has infilled pore space. Glaucony is rimmed by euhedral siderite crystals. Ground mass is mictric siderite cement. D.) Close-up of a core of a pisoid. Chamosite-apatite clay matrix that is partially replaced by siderite. Darker areas within siderite is rhodochrosite (rd); rhodochrosite appears darker on backscatter images because of a lower Fe content. E.) Matrix of the pisoidal ironstone with micritic siderite cement. Brighter areas are siderite, darker blebs at the cores are rhodochrosite. F.) Close-up of laminae of a pisoid.

Depositional and diagenetic history of pisoidal ironstone

Observations from the pisoidal ironstone support a complex history for the formation of this rock. The mineralogy, texture, and replacement relationships lead to the interpretation that there were significant changes in the environment at this stratigraphic interval. The diagenetic history of the rock is interpreted as follows. First, mud with high organic content and probably significant amounts of kaolinite (Mücke and Farshad, 2005) is deposited. The high organic content adds to the increased concentrations of $\mathrm{Al}, \mathrm{Fe}$, and $\mathrm{Mn}$. Second, biogenically mediated pisoids are formed. The cauliflower texture on the rims of the pisoids are interpreted as a product of bacterial or algal growth during the formation of the pisoids. Third, the kaolinitic mud is replaced by a clay mixture of chamosite and apatite and at least three generations of carbonate. It remains unclear as to whether the siderite replacement occurred before, after, or during the clay replacement. Some pisoids are composed entirely of siderite while others are primarily clay. It is most likely however, that the clay preceded the carbonate replacement because of the overall 
SAMPLE 07-PEEL-41 Carbonate analysis

Analysis 41-CC1 41-CC2 41-CC3 41-CC4 41-CC5 41-CC6 41 -CC7 41-CC8

$\begin{array}{lllllllll}\mathrm{CaO} & 2.4 & 2.6 & 6.0 & 6.7 & 4.0 & 7.2 & 7.1 & 17.6\end{array}$

$\begin{array}{lllllllll}\mathrm{FeO} & 38.3 & 42.8 & 37.5 & 35.2 & 40.4 & 34.8 & 38.9 & 5.7\end{array}$

$\begin{array}{lllllllll}\mathrm{MnO} & 14.9 & 8.6 & 7.0 & 12.5 & 8.2 & 9.2 & 8.1 & 33.4\end{array}$

$\begin{array}{lllllllll}\mathrm{MgO} & 6.0 & 6.9 & 9.8 & 5.5 & 7.3 & 8.5 & 6.0 & 3.0\end{array}$

\begin{tabular}{lrrrrrrrr}
$\mathrm{SiO}_{2}$ & 0.2 & 0.1 & 0.1 & 1.2 & 0.4 & 0.3 & 0.4 & 0.5 \\
\cline { 2 - 8 } TOTAL & 61.8 & 61.0 & 60.4 & 61.0 & 60.4 & 60.1 & 60.5 & 60.1
\end{tabular}

TOTAL

\begin{tabular}{lllllllll}
$\mathrm{Ca}$ & 0.1 & 0.1 & 0.2 & 0.2 & 0.2 & 0.3 & 0.3 & 0.7 \\
$\mathrm{Fe}$ & 1.1 & 1.3 & 1.1 & 1.0 & 1.2 & 1.0 & 1.1 & 0.2 \\
$\mathrm{Mn}$ & 0.4 & 0.3 & 0.2 & 0.4 & 0.2 & 0.3 & 0.2 & 1.0 \\
$\mathrm{Mg}$ & 0.3 & 0.4 & 0.5 & 0.3 & 0.4 & 0.4 & 0.3 & 0.2 \\
$\mathrm{Si}$ & 0.0 & 0.0 & 0.0 & 0.0 & 0.0 & 0.0 & 0.0 & 0.0 \\
\cline { 2 - 8 } & 2.0 & 2.0 & 2.0 & 2.0 & 2.0 & 2.0 & 2.0 & 2.0
\end{tabular}

Analysis 41-CC9 41-CC10 41-CC11 41-CC12 41-CC13 41-CC14 41-CC15 41-CC16

$\mathrm{CaO}$

$\begin{array}{llllllll}7.7 & 7.6 & 13.9 & 7.0 & 20.2 & 7.8 & 17.4 & 7.8\end{array}$

$\mathrm{FeO}$

$\begin{array}{llllllll}41.5 & 43.4 & 5.6 & 44.7 & 2.5 & 42.2 & 2.7 & 43.7\end{array}$

$\begin{array}{lllllllll}\mathrm{MnO} & 8.1 & 2.5 & 38.0 & 5.8 & 34.4 & 6.6 & 39.0 & 5.4\end{array}$

$\begin{array}{lllllllll}\mathrm{MgO} & 3.5 & 6.2 & 2.2 & 3.6 & 1.4 & 3.7 & 2.0 & 4.1\end{array}$

$\mathrm{SiO}_{2}$

TOTAL

\begin{tabular}{rrrrrrrr}
0.2 & 0.0 & 0.1 & 0.1 & 0.6 & 0.2 & 0.7 & 0.3 \\
\hline 60.9 & 59.7 & 59.7 & 61.2 & 59.1 & 60.5 & 61.7 & 61.2
\end{tabular}

$\mathrm{Ca}$

\begin{tabular}{llllllll}
0.3 & 0.3 & 0.5 & 0.3 & 0.8 & 0.3 & 0.6 & 0.3 \\
1.3 & 1.3 & 0.2 & 1.4 & 0.1 & 1.3 & 0.1 & 1.3 \\
0.2 & 0.1 & 1.2 & 0.2 & 1.0 & 0.2 & 1.1 & 0.2 \\
0.2 & 0.3 & 0.1 & 0.2 & 0.1 & 0.2 & 0.1 & 0.2 \\
0.0 & 0.0 & 0.0 & 0.0 & 0.0 & 0.0 & 0.0 & 0.0 \\
\hline 2.0 & 2.0 & 2.0 & 2.0 & 2.0 & 2.0 & 2.0 & 2.0
\end{tabular}

* Formula basis 2 oxygens

Table 3. EPMA analysis from carbonate cement of sample 07-Peel-41. 
SAMPLE 07-PEEL-41 Pisoid clay analysis

\begin{tabular}{|c|c|c|c|c|c|}
\hline Analysis & 41-PS1 & 41-PS2 & 41-PS3 & 41-PS4 & 41-PS5 \\
\hline $\mathrm{SiO}_{2}$ & 15.5 & 17.8 & 17.9 & 15.0 & 19.1 \\
\hline $\mathrm{Al}_{2} \mathrm{O}_{3}$ & 10.9 & 12.8 & 12.9 & 10.7 & 13 \\
\hline $\mathrm{FeO}$ & 19.1 & 22.1 & 22.0 & 16.0 & 23. \\
\hline $\mathrm{MnO}$ & 0.2 & 0.2 & 0.2 & 0.3 & 0 \\
\hline $\mathrm{MgO}$ & 3.3 & 3.7 & 3.8 & 2.9 & 4. \\
\hline $\mathrm{K}_{2} \mathrm{O}$ & 0.2 & 0.2 & 0.3 & 0.6 & \\
\hline $\mathrm{CaO}$ & 22.7 & 17.9 & 17.3 & 24.5 & 14.6 \\
\hline $\mathrm{Na}_{2} \mathrm{O}$ & 0.2 & 0.1 & 0.1 & 0.3 & \\
\hline $\mathrm{P}_{2} \mathrm{O}_{5}$ & 16.9 & 13.2 & 12.3 & 18.0 & 11.1 \\
\hline $\mathrm{Cl}$ & 0.0 & 0.0 & 0.0 & 0.1 & 0.1 \\
\hline TOTAL & 89.0 & 88.0 & 86.8 & 88.4 & 86.6 \\
\hline ТОT-О & 89.0 & 88.0 & 86.8 & 88.3 & 86.5 \\
\hline Si & 2.8 & 3.3 & 3.4 & 2.7 & \\
\hline Al & 2.3 & 2.8 & 2.9 & 2.3 & 3.0 \\
\hline $\mathrm{Fe}$ & 2.9 & 3.4 & 3.5 & 2.4 & 3.6 \\
\hline $\mathrm{Mn}$ & 0.0 & 0.0 & 0.0 & 0.0 & 0.0 \\
\hline $\mathrm{Mg}$ & 0.9 & 1.0 & 1.1 & 0.8 & 1.2 \\
\hline K & 0.1 & 0.1 & 0.1 & 0.1 & 0.1 \\
\hline $\mathrm{Ca}$ & 4.4 & 3.5 & 3.5 & 4.8 & 2.9 \\
\hline $\mathrm{Na}$ & 0.1 & 0.0 & 0.0 & 0.1 & 0.1 \\
\hline$P$ & 2.6 & 2.1 & 2.0 & 2.8 & 1.8 \\
\hline \multirow[t]{2}{*}{$\mathrm{Cl}$} & 0.0 & 0.0 & 0.0 & 0.0 & 0.0 \\
\hline & 16.2 & 16.3 & 16.3 & 16.1 & 16.4 \\
\hline Analysis & 41-PS6 & 41-PS7 & 41-PS8 & 41-PS9 & $41-P S 10$ \\
\hline $\mathrm{SiO}_{2}$ & 21.8 & 20.9 & 22.9 & 22.8 & 23.7 \\
\hline $\mathrm{Al}_{2} \mathrm{O}_{3}$ & 14.7 & 13.7 & 13.7 & 17.0 & 15.7 \\
\hline $\mathrm{FeO}$ & 25.6 & 23.2 & 24.3 & 26.0 & 23.0 \\
\hline $\mathrm{MnO}$ & 0.2 & 0.1 & 0.1 & 0.2 & 0.3 \\
\hline $\mathrm{MgO}$ & 4.9 & 4.3 & 4.1 & 4.3 & 3.9 \\
\hline $\mathrm{K}_{2} \mathrm{O}$ & 0.4 & 0.4 & 0.2 & 0.8 & 1.1 \\
\hline $\mathrm{CaO}$ & 10.7 & 14.0 & 12.0 & 8.7 & 10.5 \\
\hline $\mathrm{Na}_{2} \mathrm{O}$ & 0.2 & 0.1 & 0.1 & 0.2 & 0.4 \\
\hline $\mathrm{P}_{2} \mathrm{O}_{5}$ & 7.9 & 10.0 & 9.2 & 6.6 & 7.6 \\
\hline $\mathrm{Cl}$ & 0.1 & 0.0 & 0.0 & 0.1 & 0.3 \\
\hline TOTAL & 86.4 & 86.7 & 86.6 & 86.7 & 86.5 \\
\hline TOT-O & 86.4 & 86.7 & 86.6 & 86.7 & 86.4 \\
\hline ১I & 4.1 & 3.9 & 4.2 & 4.3 & 4.4 \\
\hline Al & 3.3 & 3.0 & 3.0 & 3.8 & 3.4 \\
\hline $\mathrm{Fe}$ & 4.0 & 3.6 & 3.8 & 4.1 & 3.6 \\
\hline$M n$ & 0.0 & 0.0 & 0.0 & 0.0 & 0.0 \\
\hline $\mathrm{Mg}$ & 1.4 & 1.2 & 1.1 & 1.2 & 1.1 \\
\hline K & 0.1 & 0.1 & 0.0 & 0.2 & 0.3 \\
\hline $\mathrm{Ca}$ & 2.2 & 2.8 & 2.4 & 1.7 & 2.1 \\
\hline $\mathrm{Na}$ & 0.1 & 0.0 & 0.0 & 0.1 & 0.2 \\
\hline$P$ & 1.3 & 1.6 & 1.4 & 1.1 & 1.2 \\
\hline \multirow[t]{2}{*}{$\mathrm{Cl}$} & 0.0 & 0.0 & 0.0 & 0.0 & 0.1 \\
\hline & 16.4 & 16.3 & 16.1 & 16.4 & 16.3 \\
\hline
\end{tabular}

* Formula basis 24 oxygens calculated on $\mathrm{O}, \mathrm{Cl}$

Table 4. EPMA analysis from apatite-chamosite clay mixture of a pisoid. 
pervasiveness of the siderite cement throughout the rock, and because previous studies report that carbonate commonly replaces chamosite (Mücke and Farshad, 2005). Chamosite is recrystallized or transformed from the parent material under reducing conditions caused by decomposing organic material through bacterial oxidation (Mücke and Farshad, 2005). Mg is supplied by seawater. Carbonate replacement was initiated in a Mn-reducing environment indicated by early generation rhodochrosite. A switch to an Fe-reducing environment resulted in further replacement by siderite cement. At least two generations of siderite replacement are evident. The first is characterized by sparry siderite cement that replaced the majority of the pisoids. The second is characterized by micritic siderite cement that replaced the majority of the matrix. Edges of the pisoids are intergrown with the matrix, a secondary texture from overprinting of siderite. Replaced pisoids are brittle and may be fractured, fractures are infilled by late-generation micritic siderite cement. Fourth and finally, authigenic Al-rich glaucony infills pore spaces that are rimmed by carbonate. Glaucony occurs in settings with low sedimentation rates at the sediment-water interface (Eder et al., 2007). Fe has been preferentially taken up by siderite, supplying high concentrations of Al for the glaucony. 
SAMPLE 07-PEEL-41 Glaucony analysis

\begin{tabular}{|c|c|c|c|c|}
\hline Analysis & 41-GL1 & 41-GL2 & 41-GL3 & 41-GL4 \\
\hline $\mathrm{SiO}_{2}$ & 50.8 & 51.1 & 49.7 & 51.6 \\
\hline $\mathrm{Al}_{2} \mathrm{O}_{3}$ & 13.1 & 14.0 & 12.9 & 12.8 \\
\hline $\mathrm{TiO}_{2}$ & 0.1 & 0.1 & 0.1 & 0.1 \\
\hline $\mathrm{Cr}_{2} \mathrm{O}_{3}$ & n.d. & n.d. & n.d. & n.d. \\
\hline $\mathrm{Fe}_{2} \mathrm{O}_{3}$ & 19.0 & 18.5 & 20.8 & 19.5 \\
\hline $\mathrm{MnO}$ & 0.2 & 0.2 & 0.1 & 0.2 \\
\hline $\mathrm{MgO}$ & 3.1 & 3.3 & 3.3 & 3.2 \\
\hline $\mathrm{CaO}$ & 0.6 & 0.5 & 0.5 & 0.5 \\
\hline $\mathrm{K} 2 \mathrm{O}$ & 6.2 & 5.8 & 5.8 & 6.0 \\
\hline $\mathrm{Na}_{2} \mathrm{O}$ & 0.4 & 0.3 & 0.2 & 0.1 \\
\hline $\mathrm{Cl}$ & 0.3 & 0.1 & 0.0 & 0.0 \\
\hline $\mathrm{F}$ & n.d. & n.d. & n.d. & n.d. \\
\hline TOTAL & 93.7 & 93.8 & 93.4 & 93.9 \\
\hline TOT-O & 93.6 & 93.8 & 93.4 & 93.9 \\
\hline Si & 7.2 & 7.1 & 7.0 & 7.2 \\
\hline \multirow[t]{2}{*}{ Al } & 0.8 & 0.9 & 1.0 & 0.8 \\
\hline & 8.0 & 8.0 & 8.0 & 8.0 \\
\hline Al & 1.3 & 1.4 & 1.2 & 1.3 \\
\hline $\mathrm{Ti}$ & 0.0 & 0.0 & 0.0 & 0.0 \\
\hline $\mathrm{Cr}$ & n.d. & n.d. & n.d. & n.d. \\
\hline $\mathrm{Fe}$ & 2.0 & 1.9 & 2.2 & 2.1 \\
\hline $\mathrm{Mn}$ & 0.0 & 0.0 & 0.0 & 0.0 \\
\hline \multirow[t]{2}{*}{$\mathrm{Mg}$} & 0.6 & 0.7 & 0.7 & 0.7 \\
\hline & 4.0 & 4.1 & 4.1 & 4.1 \\
\hline $\mathrm{Ca}$ & 0.1 & 0.1 & 0.1 & 0.1 \\
\hline K & 1.1 & 1.0 & 1.0 & 1.1 \\
\hline \multirow[t]{2}{*}{$\mathrm{Na}$} & 0.1 & 0.1 & 0.1 & 0.0 \\
\hline & 1.3 & 1.2 & 1.2 & 1.2 \\
\hline $\mathrm{Cl}$ & 0.1 & 0.0 & 0.0 & 0.0 \\
\hline \multirow[t]{2}{*}{$F$} & n.d. & n.d. & n.d. & n.d. \\
\hline & 0.1 & 0.0 & 0.0 & 0.0 \\
\hline
\end{tabular}

Table 5. EPMA analysis of glaucony from sample 07-Peel-41. 


\subsection{Biostratigraphy}

A total of 62 benthic foraminiferal species were identified and five zonal markers were established spanning Early Albian to Turonian time (Fig. 19). Each zonal marker is associated with an assemblage of partly longer ranging species that show increased abundance within the zone most likely as a response to favorable paleoenvironmental conditions (Fig. 20). Where possible, zonal markers established elsewhere in western Arctic regions are used in a new foraminiferal stratigraphic framework proposed here. All zonal markers, with the exception of Quadrimorphina albertensis, are agglutinated taxa that tend to range longer than calcareous taxa.

Quadrimorphina albertensis Zone

In the Hume River section the Quadrimorphina albertensis Zone was found in the lower Arctic Red Formation (Fig. 21). Samples of the underlying Martin House Formation were barren of foraminifera. However, this zone is projected down to the Martin House Formation based on foraminifera recovered in equivalent strata exposed along the Imperial River (McNeil, 2007).

The Quadrimorphina albertensis Zone was first described by Wall (1983) for the Eastern Sverdrup Basin. It was dated as Early Albian based on associated ammonites (Wall, 1983). This zone is at least partly correlative with the Early Albian Gaudryina tailleuri Zone described for the Arctic Slope of Alaska (Bergquist, 1966; Sliter, 1981; Tappan, 1962). The upper boundary of this zone is drawn at the last 


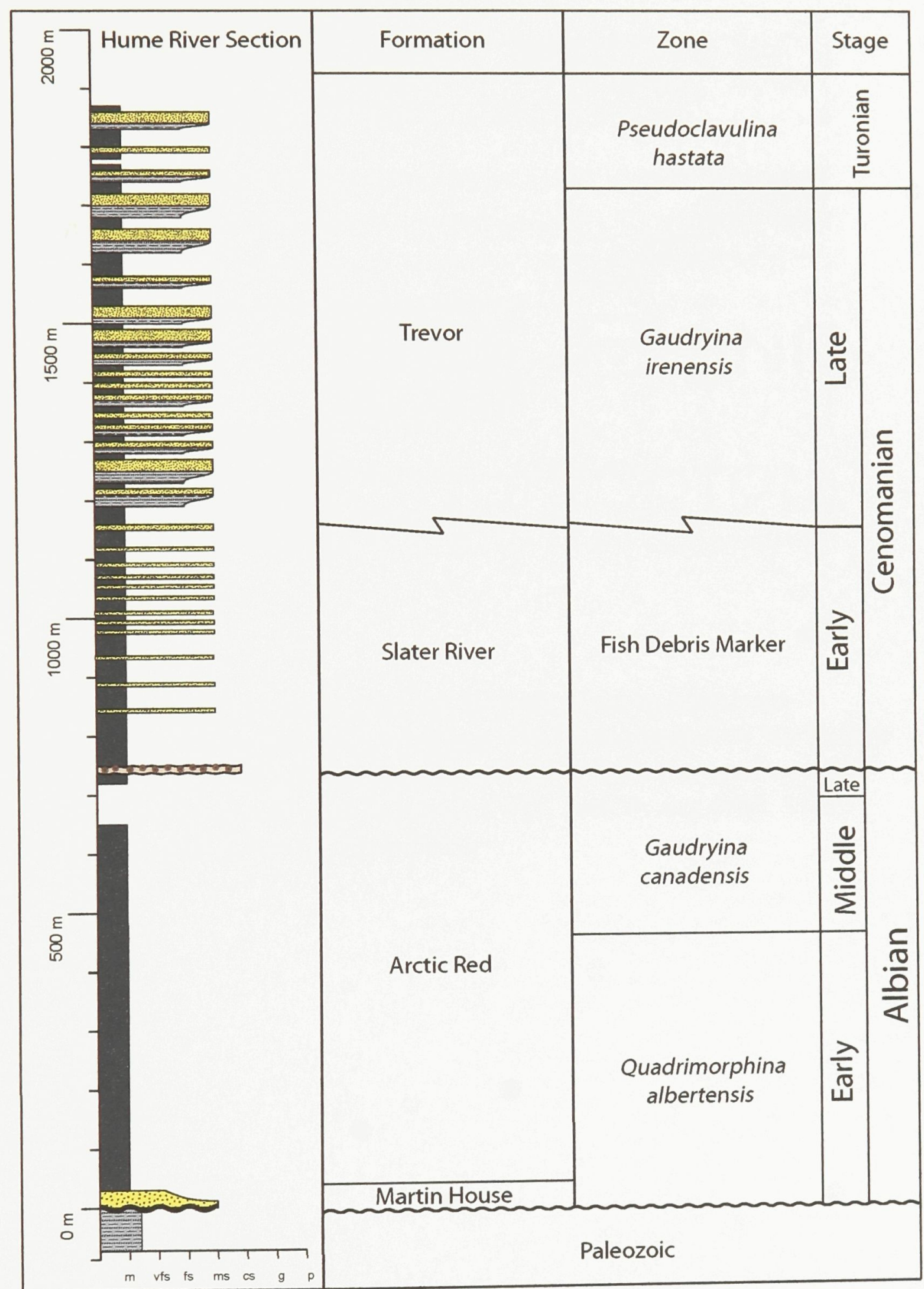

Figure 19. New lithostratigraphic framework and foraminiferal zonation for the Peel region correlated with simplified geology from the Hume River reference section. 


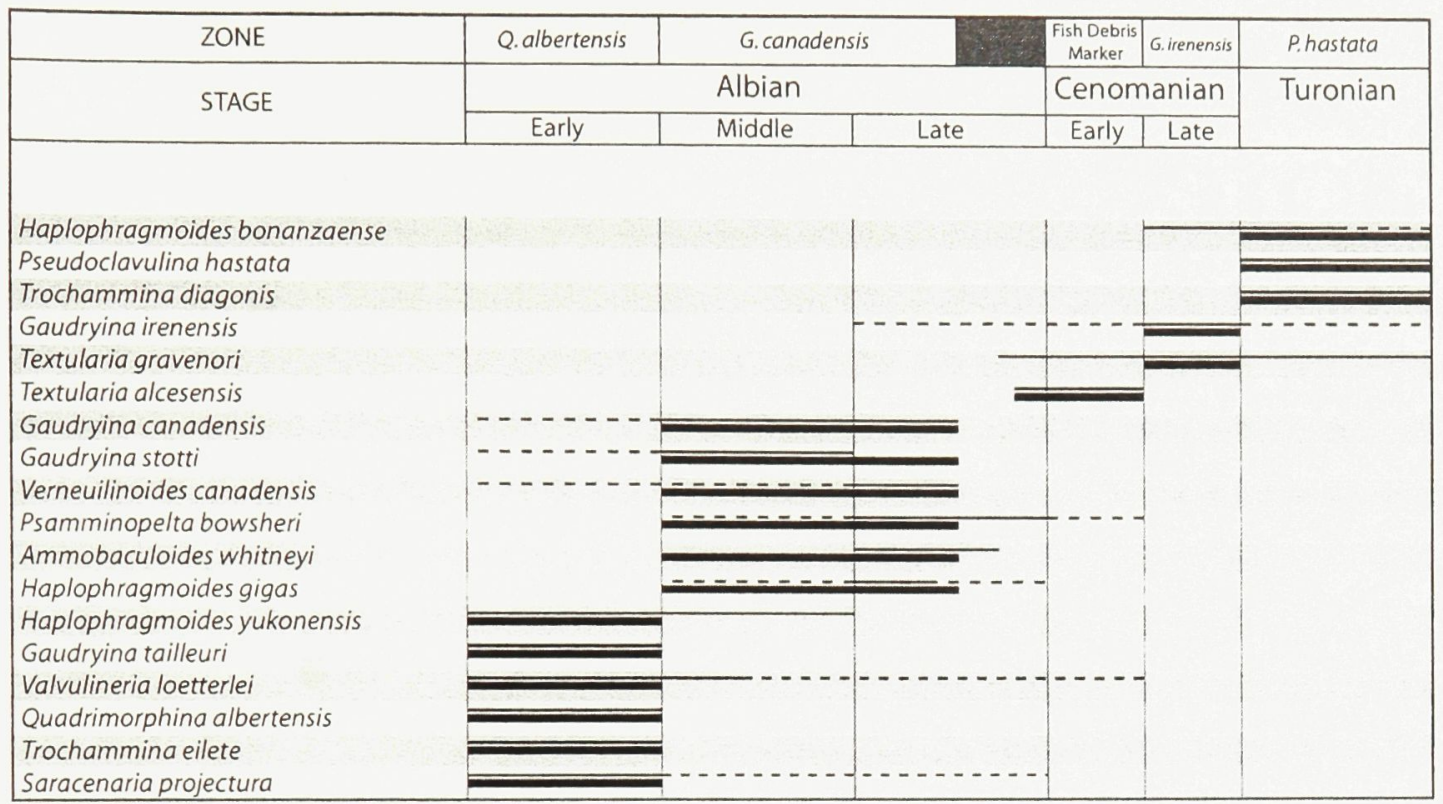

Figure 20. Reported ranges (thin line) of selected foraminiferal species from Cretaceous strata of Alaska (Berquist, 1966; Tappan, 1962), the Beaufort-Mackenzie area (McNeil, 1996), the Arctic Islands (Sliter, 1981; Wall, 1983); the southern WIS (Caldwell et al., 1993 \& 1978; McNeil and Caldwell, 1981; Mellon and Wall, 1956; Stelck and Leckie, 1990); and this study (thick line) 


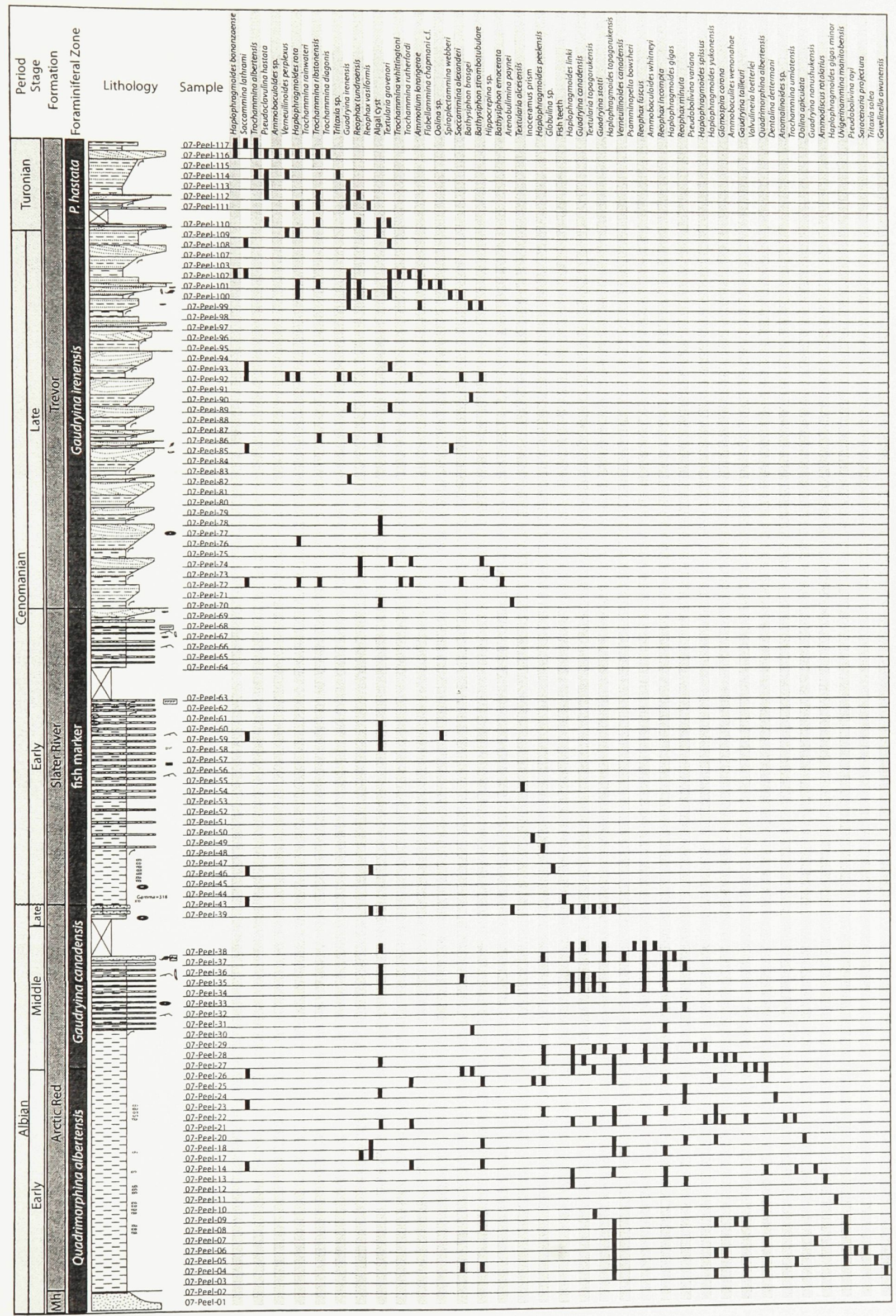

Figure 21. Foraminiferal species occurences from Hume River section. 
occurrence of Quadrimorphina albertensis and overall loss of calcareous faunal elements. Diagnostic taxa of this zone include:

Quadrimorphina albertensis Mellon and Wall 1956

Haplophragmoides yukonensis Chamney 1978

Gaudryina tailleuri (Tappan) 1957

Valvulineria loetterli (Tappan) 1940

Saracenaria projectura Stelck and Wall 1956

Conorboides umiatensis (Tappan) 1957

Diagnostic taxa from the Martin House Formation at Imperial River include Valvulineria loetterlei, Gaudryina tailleuri and Conorboides umiatensis (McNeil, 2007), which are faunal elements of the Quadrimorphina albertensis Zone (Wall, 1981). The calcareous zonal marker species is linked to the transgression associated with the basal shales of the Arctic Red Formation bringing increasing marine and deeper environments to the region.

Gaudryina canadensis Zone

The newly proposed Gaudryina canadensis Zone extends through the upper part of the Arctic Red Formation (Fig. 21). This zone contains numerous diagnostic species described from the Middle to Late Albian Verneuilinoides borealis Zone (Bergquist, 1958a; Tappan, 1962). Although no specimens of Verneuilinoides borealis were retrieved, due to common elements I consider these two zones as time equivalent. The upper boundary of this zone is defined by a disconformity and a coinciding total or temporary loss of Albian species. Lithologically, this boundary is the pisoidal ironstone. This discontinuity can be recognized in seismic profiles and 
on wireline logs by a high kick in gamma ray values, and is interpreted as a marine flooding surface overlying the erosional horizon (Hadlari et al., 2009) (Fig. 13). For the southern part of the Western Interior Plains, the Middle to Late Albian interval is characterized by three foraminiferal zones (Caldwell et al., 1993; Caldwell et al., 1978). These include, in ascending age, the Gaudryina nanushukensis, Haplophragmoides gigas, and Miliammina manitobensis zones. The latest Albian Miliammina manitobensis Zone is further subdivided into the Verneuilina canadensis, Haplophragmoides postis goodrichi, and Haplophragmium swareni subzones. The Gaudryina canadensis Zone, as proposed here, includes faunal elements of all these zones with the exception of the subzonal markers Haplophragmoides postis goodrichi and Haplophragmium swareni. The lack of these marker species suggests that the uppermost part of the latest Albian strata might be missing in this section (Figs. 4, 20) as also documented on a regional scale by Dixon (1999). Diagnostic taxa of the Gaudryina canadensis Zone include:

Gaudryina canadensis Cushman 1943

Gaudryina stotti Chamney 1978

Verneuilinoides canadensis (Cushman) 1927

Psamminopelta bowsheri Tappan 1957

Ammobaculoides whitneyi (Cushman and Alexander) 1930

Haplophragmoides gigas Cushman 1927

Fish Debris Marker

The Gaudryina canadensis Zone is overlain by a nearly barren interval that spans approximately 450 meters of section (Fig. 21). The interval is bound by the pisoidal ironstone at the base and a transgressive pebble lag at the top. These strata are characterized by the occurrence of fish teeth, Inoceramus prisms, and algal cysts 
that are typical elements of Lower Cenomanian strata basin-wide (Schröder-Adams et al., 1996). An Early Cenomanian age is also supported by a single occurrence of Textularia alcesensis, a marker for a zone spanning the Albian/Cenomanian boundary in NE British Columbia and NW Alberta (Caldwell et al., 1978) and occurring in the Lower Cenomanian Sully Formation above the base of fish scales horizon in the Liard Basin (Jowett, 2004) (Fig. 20). East of the Peel Plateau in the Mackenzie Plain area, this disconformity separates Albian Arctic Red from ?Upper Cenomanian-Turonian strata, there named the Slater River Formation (Dixon, 1999). The stratal package between the Arctic Red and Trevor formations in the Peel Plateau, which is bound by distinct disconformities is newly referred to as the Slater River Formation, using terminology from the neighbouring Mackenzie Plain area (Hadlari et al., 2009) (Fig. 3). Due to the lack of age-diagnostic faunal elements, its age is determined by the underlying and overlying foraminiferal zones and is placed within the Early Cenomanian.

\section{Gaudryina irenensis Zone}

The Gaudryina irenensis Zone extends through the lower part of the Trevor Formation (Fig. 21). This zone was first described by Berquist (1958a) characterizing the Cenomanian of Northern Alaska. This Cenomanian designation was followed by Tappan (1962). From the Peace River district a Gaudryina irenensis Subzone was described, narrowing the age designation to Late Cenomanian (Caldwell et al., 1978; Stelck and Wall, 1955). In the Peel Plateau, the base of the zone is identified by a sudden reappearance of foraminifera, a common 
phenomenon throughout the Western Interior Plains associated with Upper Cenomanian strata (Schröder-Adams et al. 1996). Some species identified within this interval have reported ranges into the Turonian, however, a Late Cenomanian age is preferred for this zone (Fig. 20). Diagnostic taxa for this zone include:

Gaudryina irenensis Stelck and Wall 1955

Textularia gravenori Stelck and Wall 1955

Pseudoclavulina hastata Zone

The Pseudoclavulina hastata Zone extends throughout the upper Trevor Formation (Fig. 21). In Alaska this zone was first described for Turonian strata by Berquist (1958b) and later recognized by Tappan (1962). The base of this interval coincides with the first occurrence of the zonal marker species although a gradational faunal change with the underlying Gaudryina irenensis Zone is indicated by several species ranging from the Cenomanian into the Turonian. This zone represents the highest stratigraphic interval sampled in this study. Diagnostic taxa for this zone include:

Pseudoclavulina hastata Cushman 1927

Haplophragmoides bonanzaense Stelck and Wall 1954 Trochammina diagonis (Carsey) 1926

A Turonian age for the uppermost Trevor Formation is further supported by macrofossils collected from the Hume River by Yorath and Cook (1981). 


\section{DISCUSSION}

\subsection{Stratigraphic Revision en route to Sequence Stratigraphy}

Integration of sedimentology and micropaleontology as studied in the Hume reference section leads to revisions of the stratigraphic framework in the Peel area allowing for consistent correlations to neighbouring regions. Most importantly, the well established disconformity at the Albian-Cenomanian boundary (e.g. Dixon, 1999, 2004; Koch and Brenner, 2009) was discovered which led to the introduction of the Slater River Formation in the Peel area. While it is not feasible to do a robust sequence stratigraphic analysis on just one section and limited well log coverage, this study introduces interpretations that work towards a sequence stratigraphic framework.

The Martin House Formation is the Lower Albian basal transgressive marine unit that unconformably overlies Paleozoic strata. A pebbly sandstone at the contact between Martin House Formation and the underlying Devonian Imperial Formation marks the onset of Cretaceous sea-level rise in this region and is interpreted as a transgressive surface of erosion. Within Martin House Formation, two pulses of relative sea-level rise are recorded as the basin subsided in response to the onset of the Columbian orogeny (Fig. 22). The first interval of relative sea level rise is characterized by strongly bioturbated interbedded sandstone and mudrock interpreted to represent a lower shoreface setting. The second interval is characterized by an upward fining succession of storm deposits in the transition 
from middle to lower shoreface, which grade into offshore marine mudrocks of the Arctic Red Formation.

The Lower to Middle Albian Arctic Red Formation consists mainly of a thick package of offshore marine mudrock that records infill of this deep foreland basin. Towards the top of Arctic Red Formation thin beds of siltstone and sandstone begin to appear, indicating shallowing. Benthic foraminifera respond to this facies change with a gradual disappearance of several species marked by the changeover from the Quadrimorphina albertensis Zone to the Gaudryina canadensis Zone. A significant covered interval obscures the top interval of the formation between the onset of sandstones and the pisoidal ironstone that delineates the upper boundary of this formation. Consequently, it remains uncertain how rapid regression was and to what amount shallow water facies are preserved. At the top of the Arctic Red Formation, the sea regressed to the extent of subaerial exposure and paleosol development. This event corresponds with a nearly complete loss of foraminiferal fauna in the biostratigraphic record, with assemblages missing that are typical for the Latest Albian. It is unknown how much time is missing, but the subsequent foraminiferal assemblage established within the seaway is of Cenomanian age.

The pisoidal ironstone, interpreted as an altered paleosol, suggests subaerial exposure of this region that is in turn supported by biostratigraphic data, field observations, seismic data from Hadlari et al. (2009), and geochemical data. Faunal 


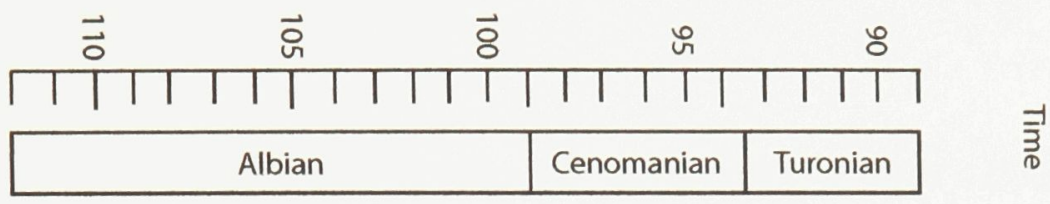
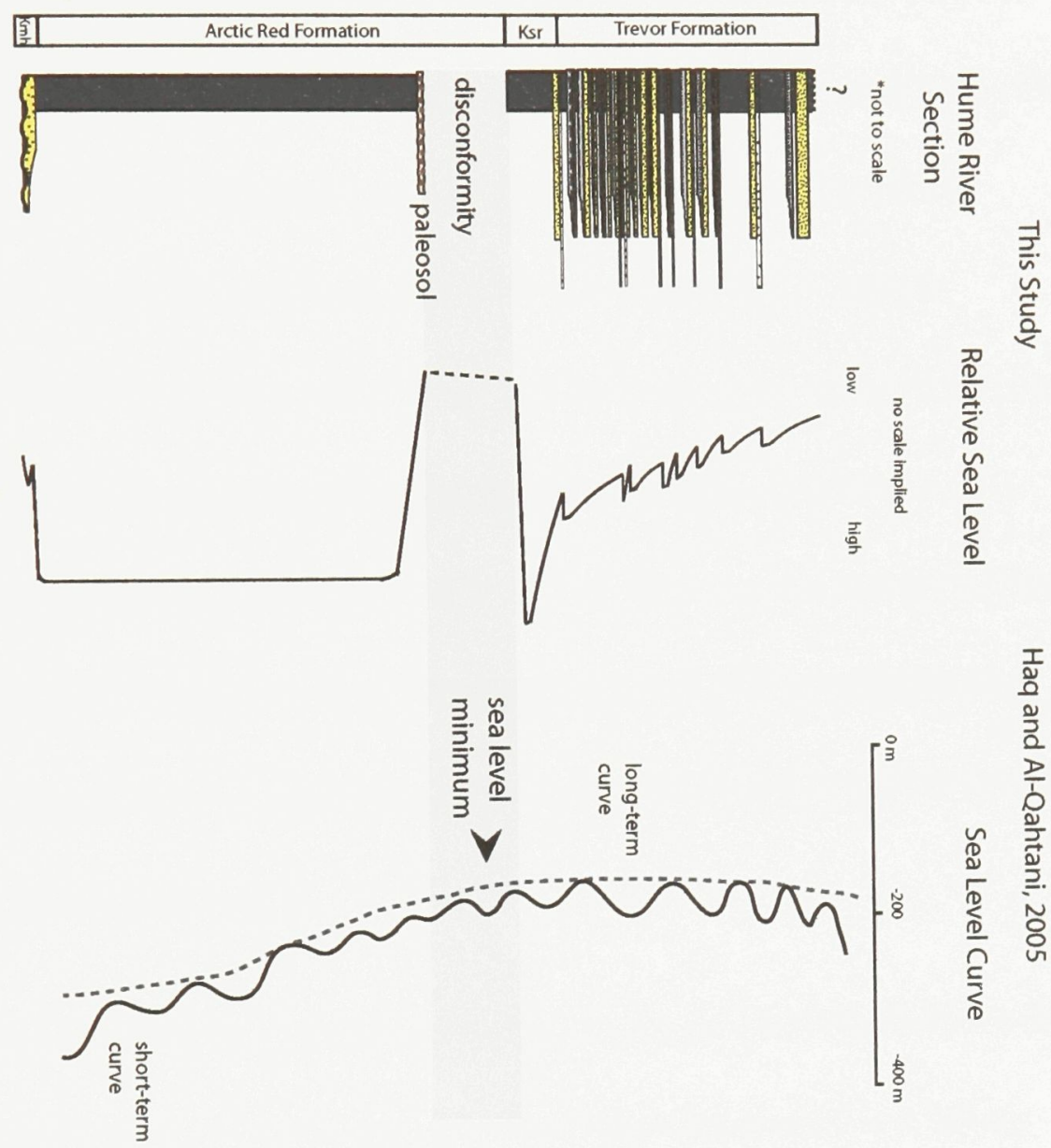

Figure 22. Interpreted sea-level curve for Peel region. 
data support a major paleoenvironmental change because of the nearly complete loss of fauna at this horizon and missing foraminiferal zones associated with a hiatus. In outcrop this horizon is directly overlain by an interval of mudrock with carbonaceous laminae and wood fragments, supporting a marginal marineterrestrial environment. The paleosol is located 20 meters below a highly radioactive mudrock, which provides a direct correlation to subsurface data. Arctic Red F-47 well intersects a seismic line thats subsurface profile shows a disconformity which increasingly truncates strata eastward at this horizon (Hadlari et al., 2009). Rock-Eval data sampled from the mudrock directly overlying the pisoidal ironstone returned type III kerogen with an anomalously high OI value, again supporting terrestrial influence.

Throughout western North America and elsewhere in the world there is a well documented unconformity at the Albian-Cenomanian boundary pointing towards a global sea-level fall (Dixon, 1993; Koch and Brenner, 2009). This unconformity was previously unreported in the Peel Plateau, however, Dixon (1993, 1999) speculated that it is most likely present, although was unable to place it due to limited biostratigraphic control.

In the Canadian Arctic, the Albian-Cenomanian unconformity has been labeled a "breakup" unconformity (Dixon, 1993; Embry and Dixon, 1990). A breakup unconformity is the result of the switch from rift to drift phases during continental breakup. In this case it represents the boundary between these phases during the 
development of the Canada Basin (Embry and Dixon, 1990). While time correlative, the disconformity discovered in this study cannot be labeled a breakup unconformity because it does not meet the criteria of such (see Embry and Dixon, 1990). However, subsequent to continental breakup there is a major decrease in subsidence rates of marginal basins due to thermal decay during drift phase (Embry and Dixon, 1990). This may have had an impact on the northern Western Interior Basin and been a contributing factor to the creation of the disconformity.

Other studies have attributed the Albian-Cenomanian unconformity to a global eustatic lowstand at approximately 97 m.y. (e.g. Haq and Al-Qahtani, 2005; Koch and Brenner, 2009; Pattison and Walker, 1994; Sahagian et al., 1996). The disconformity and sea-level minimum that straddles the Albian-Cenomanian boundary in Peel Plateau correlates approximately with Haq and Al-Qahtani's (2005) global minimum (Fig. 22). This suggests that the disconformity between the early Upper Albian Arctic Red Formation and Lower Cenomanian Slater River Formation is primarily the result of a global event, as opposed to a regionally tectonic driven event.

Elsewhere in the WIS there is evidence for a sea-level lowstand at the AlbianCenomanian boundary. South of the study area in western Canada, the Lower Cenomanian Fish Scales Formation disconformably overlies the Upper Albian Westgate Formation. This boundary is marked by a coarse-grained sandstone along the Alberta Foothills close to sediment sources, or by a bioclastic conglomerate or bonebed in sediment starved areas (Bloch et al., 1993). The bioclastic horizon has 
been interpreted as representing a sharp drop in relative sea level at the end of the Albian and sea-level lowstand (Leckie et al., 2000). Further south in the WIS, in eastern Nebraska, the Dakota Formation records fluvial incision from rapid sealevel fall at the Albian-Cenomanian boundary that researchers have attributed to a eustatic mechanism (Koch and Brenner, 2009). These events correlate to the disconformity separating the Arctic Red and Slater River formations in the Peel region and supports interpretation of eustatic sea-level fall at this boundary.

The newly discovered disconformity calls for a revision of the lithostratigraphic framework, and based on this work formational changes have recently been made in this region (Hadlari et al., 2009). A marker bed with distinct high gamma values located a few meters above the pisoidal ironstone allowed for regional correlations. To the east of the study area, in the Mackenzie Plains, a similar log marker has been used for regional correlations of wells and is placed near or at the base of the Slater River Formation (Dixon, 1999). The paleosol is both a sequence stratigraphic boundary and a natural place to put a formational boundary. Use of the Slater River Formation in the Peel region conforms to the lithostratigraphic terminology used in the Mackenzie Plain, and so the strata bound by disconformities, namely the pisoidal ironstone at the base and first pebble bed of the Trevor Formation at the top, is now known as the Slater River Formation (Hadlari et al., 2009)(Fig. 23). The Slater River Formation does not have a formal type section, only a type area of poorly exposed section along Slater River (Tassonyi, 1969)(Tassonyi, 1969)(Tassonyi, 1969)(Tassonyi, 1969)(Tassonyi, 1969)(Tassonyi, 1969) and a reference section in the East Mackay B-45 well (Dixon, 1999). I propose 
that the Hume River section be the type section for Slater River Formation because it includes the basal and upper contacts of the formation and has excellent continuous exposure (Thomson et al., in prep).

The base of Slater River Formation directly overlies the pisoidal ironstone and is characterized by mudrock with thin beds of sandstone and carbonaceous laminae, interpreted as a terrestrial to marginal marine environment. TOC values from this interval returned type III kerogen with an exceptionally high OI value, further supporting this interpretation. Above this is a thin interval of dark grey to black shale overlain by the highly radioactive mudrock, interpreted as a major flooding surface and condensed interval. The basal Slater River Formation records rapid fluctuations in sea level, moving from a terrestrial-marginal marine setting at a base level low to a condensed section at the peak of a rapid transgression and base level high, within 20 meters of section (Fig. 22). The upper 400 m of Slater River Formation is a gradual upward shallowing succession from an offshore marine to lower shoreface setting. The Slater River Formation is characterized by a low abundance of foraminifera. In parts of the southern WIS, the Lower Cenomanian Fish Scales Formation is also barren of foraminifera (e.g. Bloch, 1993; SchröderAdams, 1996). After the nearly total loss of fauna at the base of Slater River Formation, foraminiferal assemblages were slowly re-established in the seaway. The Slater River Formation is characterized by algal cysts, fish debris, and a few 
Figure 23. Diagrammatic cross section of Peel Plateau and Mackenzie Plain stratigraphy.

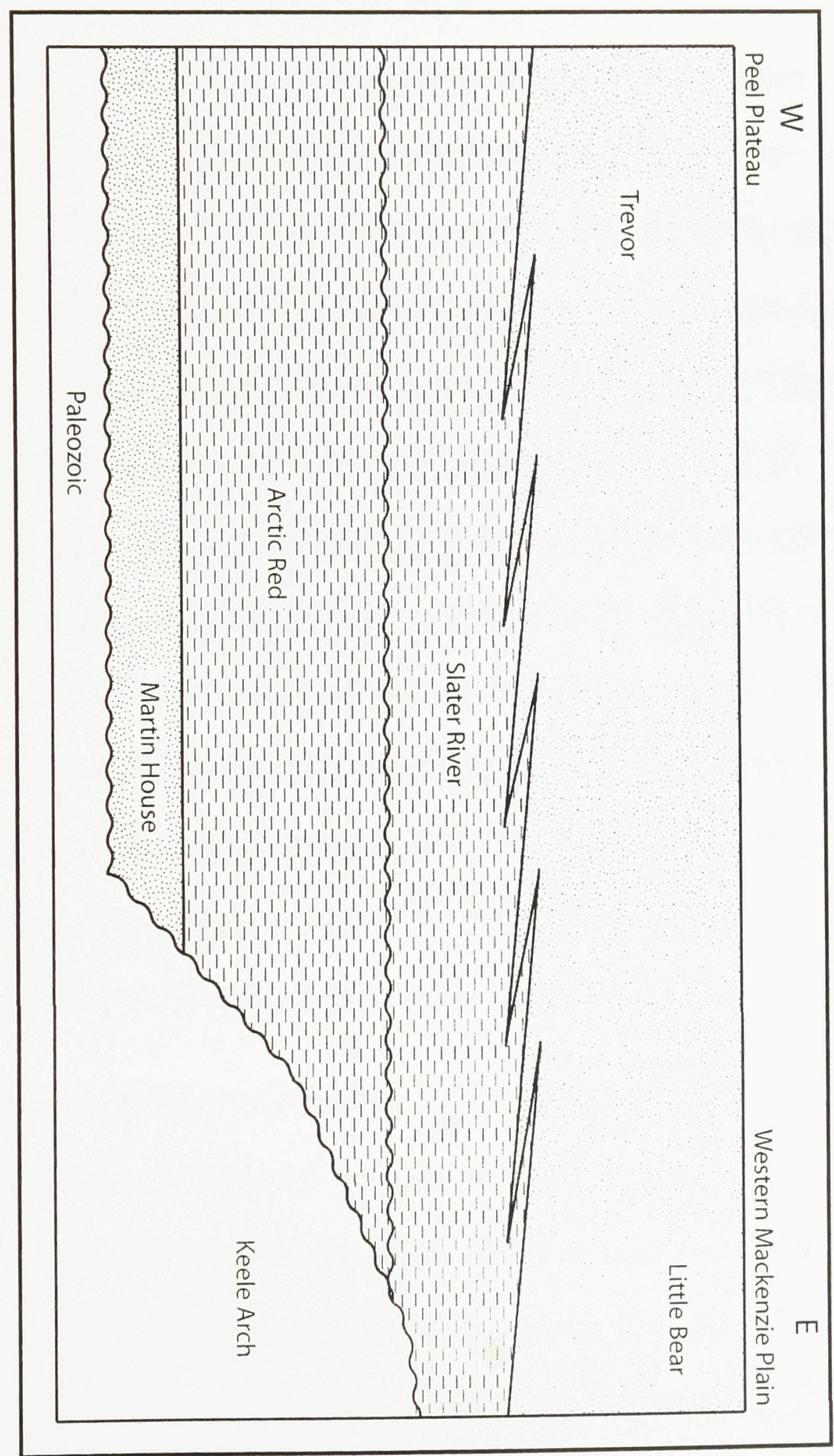


primitive forms including the taxon Textularia alcesensis, all indicative characteristics of the Cenomanian stage of the WIS (Schröder-Adams, 1996; Bloch et al., 1993; Leckie et al., 1992).

A pebble bed interpreted as a transgressive surface of erosion marks the onset of prograding, upwards coarsening parasequences that characterize the Upper Cenomanian-Turonian Trevor Formation. Directly above this first pebble bed, foraminifera reappear in the record indicating improving benthic oxygen conditions (Fig. 21). There is a total of 17 parasequences in this locality of Trevor Formation. In eight of these parasequences lag deposits of pebble beds top thick beds of amalgamated sandstone. These pebble beds are essentially high order sequence boundaries, and indicate that the shoreline was present at one point. They are overlain by shale or mudrock, interpreted as flooding surfaces. Each one of these upward shallowing successions bound by pebble lags and flooding surfaces are small scale sequences reflecting fluctuations of sea level and the basinward and landward migration of the shoreline. Overall, the Trevor Formation records pulses of relative sea-level rise followed by clastic infill and progradation of the shoreline.

When compared to Haq and Al-Qahtani's (2005) sea-level curve, some vague comparisons can be made. With the current age resolution in this area these correlations are tentative at best, but may point towards some eustatic influence (Fig. 22). It is noteworthy however, that this was a time of active tectonism and mountain building in the Canadian Cordillera, which resulted in crustal flexure and 
the eastward and northward migration of the deformation front (Dixon, 2004). Due to the fact that these deposits are located in a foreland basin setting, the high frequency, dynamic T-R patterns in the Trevor Formation are likely related more to local tectonic events than global eustatic changes.

\subsection{Paleogeography and Foraminiferal Response}

Maps of Cretaceous North American paleogeography suggest major changes in basin configuration and paleoceanographic circulation pattern (Fig. 24)(Kreitner and Plint, 2006; Williams and Stelck, 1975). Foraminiferal response can be linked to those changes in basin architecture. During Early Albian Quadrimorphina albertensis time, a wide opening connected the WIS with the Boreal Sea. This allowed for open, normal marine conditions resulting in the only interval where calcareous taxa are present in the Peel region. The northern opening of the WIS narrowed during the Middle to early Late Albian, and in response there are no calcareous forms in the Gaudryina canadensis Zone. In contrast, agglutinated species often dominate marine basins with increasing brackish salinities. During the Late Albian, the seaway became even more constricted at its northern end, which corresponds to an almost total loss of fauna, subaerial exposure and paleosol development.

Marine conditions returned to the study area sometime in the Early Cenomanian, however the environment was unfavourable for foraminifera as seen in low faunal abundances of primitive forms that are preserved from the fish debris marker. The Cenomanian is a noted time of bottom water anoxia in the WIS (e.g. Schröder-Adams et al., 2001) under which conditions were inhospitable for benthic 
foraminifera populations basinwide. Upper waters remained oxygenated and productive as indicated by the presence of fish debris and algal cysts that settled out and were preserved in anoxic bottom water conditions. During the Late Cenomanian conditions were once again favourable for foraminifera, at least in the northern part of the WIS close to the entrance of the Boreal Sea, whereas further south Cenomanian aged assemblages remain poor in diversity (e.g. Bloch, 1993). Most of the first species to recolonize this part of the basin are taxa of the genera Saccamina, Bathysiphon, and Reophax, which are primitive forms.

The Early Turonian seaway reflects sea-level highstand, although lithologies indicate a position close to the basin margin at this time as indicated by shoreface deposits. Despite a broad seaway at this time, a relatively narrow opening to the Boreal Sea in the northern portion of the WIS caused marine conditions that support the agglutinated assemblage of the Pseudoclavulina hastata Zone. Planktic foraminifera, abundant in southern parts of the seaway, do not reach the study area. This could be explained by cooler temperatures of the Boreal Sea or by increased turbidity due to proximity to the shoreline.

\subsection{Foraminiferal Abundance and Preservation}

The two dominant and visible taphonomic processes that have affected the preservation of foraminifera in this study are abrasion and silicification. The third process of dissolution, in particular of calcareous forms, is difficult to evaluate due to non-preservation, but has probably contributed significantly as well. Abrasion 

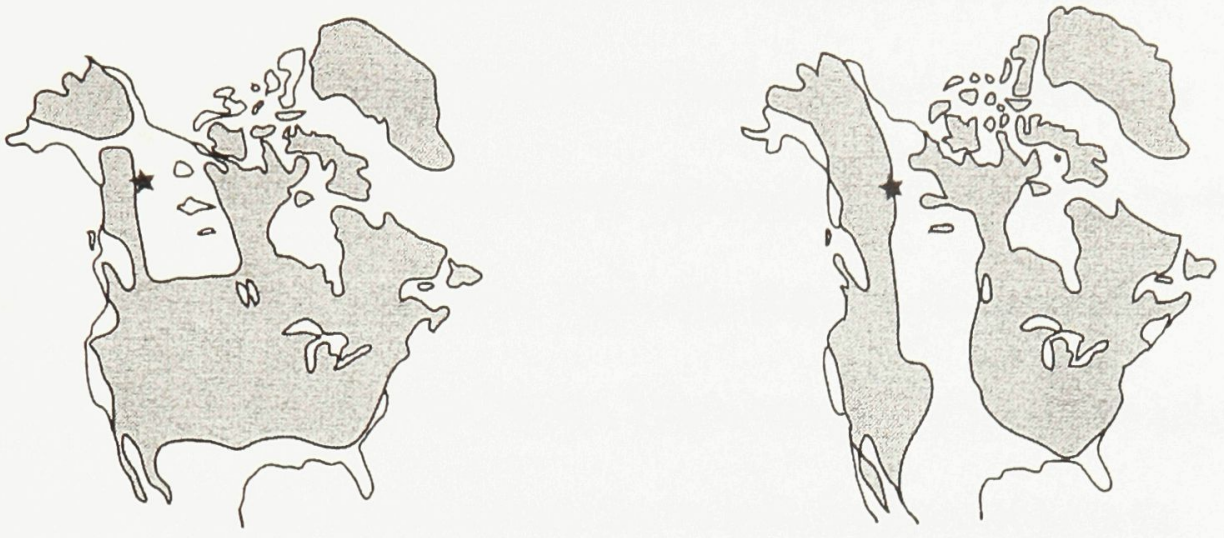

Early Albian

Early Late Albian
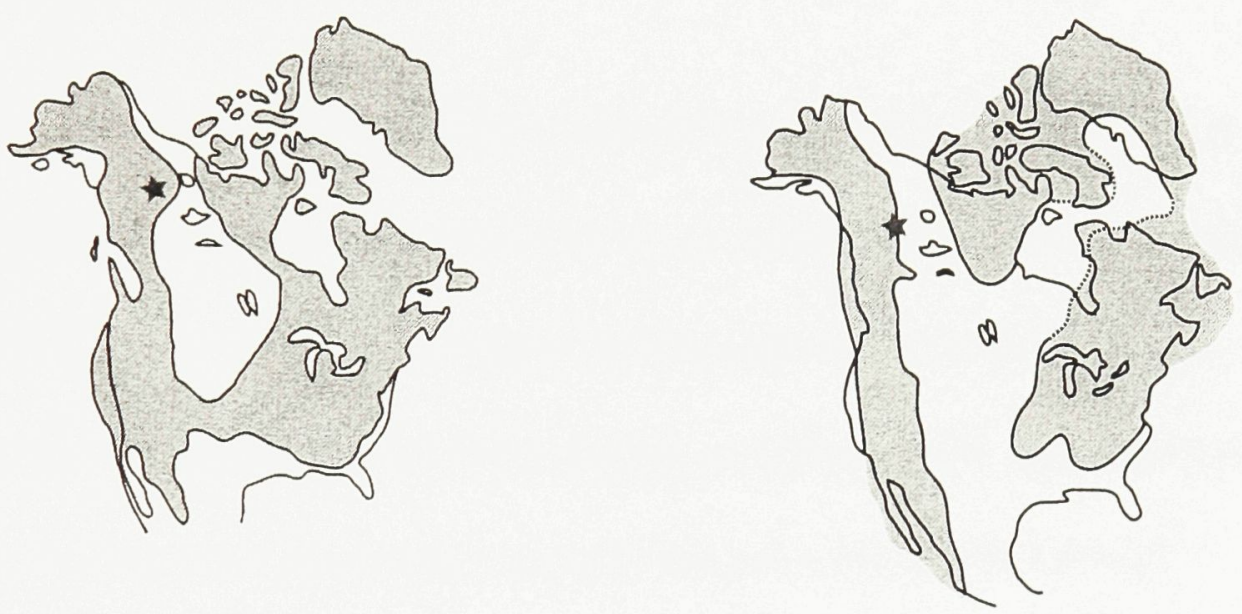

Latest Albian

Late Cenomanian

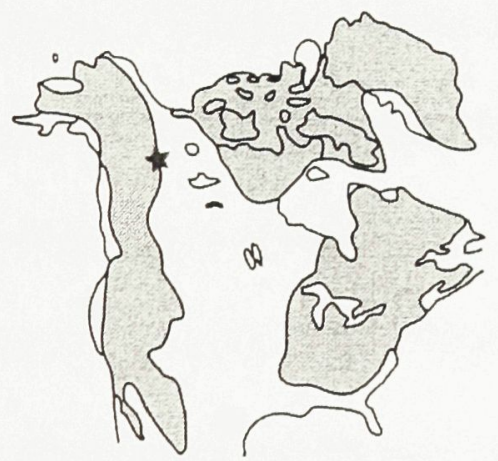

Early Turonian

modified after Williams and Stelck, 1975, and Kreitner and Plint, 2006

Figure 24. Paleogeographic maps of WIS from Early Albian to Early Turonian. Star indicates study area. 
from transport can lead to the loss of fragile tests, rounding, and destruction of diagnostic features. Foraminifera are both preserved and recovered better from fine-grained material, so microfossil samples were taken preferentially from facies that include dominantly shales and mudrocks. Typically, these rocks represent deposition in relatively low energy environments. There must have been transport of foraminiferal tests either locally or from distal facies with higher energies to cause abrasion and rounding of tests.

Samples from this study returned agglutinated foraminifera that have been silicified, and interestingly calcareous forms have been completely replaced by silica as well. McNeil (1997a) defined four diagenetic regimes based on work from the Beaufort-Mackenzie Basin. These are the early, burial, overpressured, and meteoric diagenetic regimes. During early diagenesis, pore fluids are oversaturated with respect to quartz, however, precipitation will not occur until the burial diagenetic regime sets in under conditions of above $75^{\circ} \mathrm{C}$ and at depths of approximately $2.4-8$ km (Abercrombie et al., 1994; McNeil, 1997a). Precipitation from silica saturated pore fluids is greatly controlled by temperature and mineral assemblage. The migration of fluids in shales is minimal because of low porosity and permeability but silica may be remobilized as a result of pressure solution or reactions of silica minerals, for example smectite-illite, usually beginning at shallow $(1-2 \mathrm{~km})$ depths (McNeil, 1997a). There can also be silicification in the meteoric regime from meteoric fluids, which are oversaturated in silica. Meteoric fluids also are low in 
salinity, oxidizing, and are acidic, which is a contributing cause to the dissolution of calcareous taxa (McNeil, 1997a).

Early diagenetic processes often take a toll on foraminiferal assemblages in the upper few centimeters of sediment where intense bacterial decomposition of organic matter depletes oxygen. This creates an anaerobic reduction zone, where decomposition by bacteria causes an increase in carbonic acid which may dissolve calcareous tests (Hesse, 1990; McNeil, 1997a). Dissolution of calcareous tests is a widespread and common phenomenon in many different sedimentary environments (Murray and Alve, 1999). Some of the foraminifera recovered have been partially replaced by pyrite. In fine-grained marine mud with high organic content, activity by sulphate reducing bacteria produces free $S$, which may then be preferentially taken up by Fe to form pyrite. This may be a contributing factor to pyrite replacement. Conversely, iron in the organic cement of agglutinated foraminifera can be lost to pyrite precipitation resulting in disaggregation of the test (Schröder-Adams and McNeil, 1994). Replacement by pyrite provides good preservation of tests, although not many specimens in this study have been preserved in that manner.

Foraminifera recovered in this study were minute and low in abundance. Low abundances were probably due to both poor preservation and low populations. Minute forms suggest that this area of the basin was not hospitable to foraminifera and conditions inhibited growth. It has been suggested that minute forms are the response of dysoxic environments, for example, benthic foraminiferal assemblages 
that recolonized the North Atlantic after the Cenomanian/Turonian anoxic event are minute and low in diversity (Kuhnt, 1992). This may be attributed to the fact that smaller individuals require less oxygen and take it up more efficiently, which leads to a population with minute tests in a stressed environment, particularly one with dysoxic conditions (Bernhard, 1986). This is in contrast to samples recovered from Chamney's original study area where diverse assemblages with large tests were recovered. One hypothesis is that because Chamney's study area was located further to the northwest it may have been exposed to more open marine conditions, while the Hume River area was located in a more restricted portion of the basin.

\subsection{Comparison of biostratigraphy with the type section}

There are some marked differences between the zonations originally proposed for the Martin House, Arctic Red, and Trevor formations by Mountjoy and Chamney (1969), Chamney (1978) and those proposed here. Martin House Formation was originally assigned an Aptian-Early Albian age and consisted of three zones and two subzones (Fig. 4). This study supports an Early Albian interpretation, however due to the sandy nature of the Martin House Formation exposed in the Hume River tributary, no foraminifera were recovered and age determination was based primarily on foraminifera reported in McNeil's (2007) Open File Report that addressed other localities. There are no species in common for this interval between McNeil's report and Chamney's paper, although Chamney did find the species Valvulineria loetterli higher up in the stratigraphy and used it as a zonal marker for the Upper Albian. 
Arctic Red Formation was originally determined to be Early to Late Albian age, and consisted of four zones and several subzones (Fig. 4). Here, two zones are dedicated to the Arctic Red Formation, the Quadrimorphina albertensis Zone and Gaudryina canadensis Zone, assigning an Early to early Late Albian age for this interval. The age of Arctic Red Formation is consistent between the two studies, however most zonal marker species do not correlate with the exception of part of the Gaudryina canadensis Zone. The majority of zonal marker species found in Chamney's framework from the Albian were not recovered in this study with the exceptions of: Bathysiphon brosgei, a primitive form which tends to be longer ranging; Gaudryina canadensis, used in both places to indicate Middle Albian time although in Chamney's study it was assigned a much shorter range; Trochammina rainwateri, found here much higher in the stratigraphy in Turonian-aged strata; and Valvulineria loetterlei, here used as a diagnostic species for the Early Albian Quadrimorphina albertensis Zone.

Mountjoy and Chamney (1969) and Chamney (1978) considered Arctic Red and Trevor strata as being gradational and partially time correlative. Age determination of Trevor Formation was originally based on tentative macrofossil data and suggested a Late Albian age, although it was speculated that it may possibly include Upper Cretaceous strata (Mountjoy and Chamney, 1969). In the original reports, there is no foraminiferal data from the Trevor Formation. I place the Trevor Formation in the Upper Cenomanian-Turonian. It becomes apparent that stratigraphic correlations between the type section along the Peel River and the 
Hume River section require further work based on biostratigraphic correlations to other northern regions (Schröder-Adams, in prep.)

\section{CONCLUSIONS}

1. The Hume River reference section is a significant locality for biostratigraphic and sedimentology studies. The exposed unconformable basal contact with Devonian strata and the nearly complete two km thick section is easily sampled and has excellent exposure of outcrop.

2. There are 11 facies identified from four formations. These are (F1) Pebble facies, (F2) Cross-stratified strongly bioturbated facies, (F3)Cross-stratified fine-grained sandstone facies, (F4) Mudrock facies, (F5) Interstratified shale, siltstone, and cross-laminated fine grained sandstone facies, (F6) Pisoidal ironstone facies, (F7) Black carbonaceous shale facies, (F8) Radioactive mudrock facies, (F9) Interbedded sandstone and mudrock with small scale HCS facies, (F10) Amalgamated sandstone facies, and (F11) Bioturbated mediumgrained sandstone facies.

3. Strata in the Peel Plateau record deposition of the initial transgression of the WIS in this region in two pulses of relative sea-level rise (Martin House Formation) and subsequent offshore marine sedimentation in a deep foreland basin (Arctic Red Formation). The global eustatic sea-level minimum at the Albian-Cenomanian boundary impacted paleogeography in this region with subaerial exposure and paleosol development. Rapid transgression and anoxic bottom waters during the Early Cenomanian (Slater 
River Formation) caused an almost total loss of foraminifera. The Turonian had high relative sea-level and progradation of the shoreline is recorded in upward shallowing parasequences bound by pebble lags and flooding surfaces (Trevor Formation) which record rapidly fluctuating relative sealevels predominantly influenced by regional tectonism.

4. There are five foraminiferal zones identified within the section spanning the Early Albian to Turonian. They are as follows: Early Albian Quadrimorphina albertensis Zone found in the Martin House and lower Arctic Red formations, Middle to early Late Albian Gaudryina canadensis Zone found in the upper Arctic Red Formation, Early Cenomanian fish debris marker found in the Slater River Formation, Late Cenomanian Gaudryina irenensis Zone found in the lower Trevor Formation, and Turonian Pseudoclavulina hastata Zone found in the upper Trevor Formation. Where possible, pre-existing zonal marker species were used. All marker species are agglutinated taxa, with the exception of Quadrimorphina albertensis, which tend to have longer ranges.

5. A pisoidal ironstone interpreted as a paleosol was identified at the AlbianCenomanian boundary that has a complex diagenetic history. Organic rich kaolinitic mud with pisoids was replaced by a chamosite-apatite clay mixture and at least three generations of carbonate cement. First rhodochrosite, second sparry siderite cement, and third micritic siderite cement. Finally, high-Al glaucony infilled remaining pore space.

6. A new foraminiferal biostratigraphic framework and detailed sedimentology calls for a revision in lithostratigraphy. Early Cenomanian Slater River 
Formation is newly introduced to the Peel Plateau for the interval of strata overlying the pisoidal ironstone at the top of Arctic Red Formation and underlying the first pebble lag at the base of Trevor Formation. A high gamma ray marker near the base of the formation correlates to a similar log marker used to identify Slater River Formation east of the study area in the Mackenzie Plains. This log marker is identified in outcrop as a condensed interval and provides a direct correlation to subsurface data and overlies a disconformity that can be seen in seismic profile. The Hume River is herein proposed as the type section for Slater River Formation (Thomson et al., in prep).

7. During Early Albian a wide opening in the WIS to the Boreal Sea allowed for open, normal marine conditions and in response is the only interval where calcareous taxa are present in the Peel region. The seaway narrowed during the Middle to early Late Albian and only agglutinated taxa are present suggesting brackish conditions. During the Late Albian, the seaway became much more constricted, which corresponds to almost a total loss of fauna, subaerial exposure and paleosol development. This event is correlated to Haq and Al-Qahtani's (2005) sea level minimum. Rapid transgression may have led to bottom water anoxia during the Early Cenomanian, almost no foraminifera are recovered from this interval. Conditions were once again favourable in the north for foraminifera during the Late Cenomanian. The broad seaway opening narrowed during the Early Turonian causing marine conditions that support the dominantly agglutinated assemblages of the 
Pseudoclavulina hastata Zone. Planktic foraminifera, abundant in the southern parts of the seaway, do not reach the study area. This could be explained by cooler temperatures of the Boreal Sea or increased turbidity due to shoreline proximity.

8. Foraminifera recovered in this study are minute, abraded, and highly silicified. The minute size may be attributed to inhospitable paleoenvironmental conditions in this area of the basin.

9. Few parallels can be drawn between the biostratigraphy of the type section and reference section. The type section needs to be re-examined to determine the impact of paleogeography, different facies relationships, or possibly differential faunal preservation. 


\section{TAXONOMIC LIST OF FORAMINIFERA}

The following list the original reference of each species and in some cases a more recent reference. The systematic order is based on Loeblich and Tappan (1964)

\section{Agglutinated Foraminifera}

Family ASTRORHIZIDAE Brady, 1881

Genus Bathysiphon Sars, 1872

Bathysiphon brosgei Tappan 1957

Plate 1, Figs. 1, 2

Bathysiphon brosgei Tappan, 1957. United States National Museum, Bulletin no. 215, p. 202, pl. 65, figs. 1-5.

Bathysiphon brosgei Tappan, 1962. USGS Professional Paper 236-C, p. 128, pl. 29, figs. 1-5.

Occurrence. This species was originally described by Tappan $(1957,1962)$ from the Albian-Campanian rocks of the Topagoruk and Fortress Mountain formations in the Arctic Slope of Alaska. It is found in the Arctic Red and Trevor formations in this study.

\section{Bathysiphon emacerata Chamney 1978}

Plate 1, Figs. 3, 4

Bathysiphon emacerata Chamney, 1978. Geological Survey of Canada, Bulletin no. 253, p. 9, pl. 1, figs. 4, 5 .

Occurrence. This species was originally described by Chamney (1978) for his Lower to Middle Albian Martin House and Arctic Red formations. In this study it occurs in the Trevor Formation. 


\section{Bathysiphon strombotubulare Chamney 1978}

Plate 1, Figs. 5, 6

Bathysiphon strombotubulare Chamney, 1978. Geological Survey of Canada, Bulletin no. 253 , p. 9 , pl. 1 , figs. 6,7 .

Occurrence. Chamney (1978) originally described this species from the Aptian to Early Albian Martin House formation. In this study it occurs in the Arctic Red and Trevor formations.

Family SACCAMMINIDAE Brady, 1884

Genus Saccammina Sars, 1869

Saccammina alexanderi (Leoblich and Tappan) 1950

Plate 1, Figs. 7, 8

Porteonina alexanderi Loeblich and Tappan, 1950. University of Kansas

Paleontological Contributions, Protozoa, art. 3, p. 5, pl. 1, figs. 1, 2.

Saccammina alexanderi (Loeblich and Tappan); Eicher, 1960. Peabody Museum of Natural History Bulletin no. 15, p.55, pl. 3, figs. 1, 2.

Occurrence. This species was originally described from the Lower Cretaceous Kiowa Shale of Kansas. It is recognized in the Arctic Red and Trevor formations in this study.

\section{Saccammina lathrami Tappan 1960}

Plate 1, Figs. 9, 10

Saccammina lathrami Tappan, 1960. American Association of Petroleum Geologists, Bulletin vol. 44, no. 3, p. 289, pl. 4, figs. 1, 2.

Saccammina lathrami Tappan, 1962. USGS Professional Paper 236-C, p. 129, pl. 29, figs. 21-27.

Occurrence. This species is recognized in strata ranging Late Albian to Turonian. It is found in the Grandstand, Topagoruk, Seabee, Torok, and Ninuluk formations in the Arctic Slope of Alaska. In this study it occurs in the Arctic Red, Slater River, and Trevor formations. 
Family AMMODISCIDAE Reuss, 1862

Genus Glomospira Rzehak, 1888

Glomospira corona Cushman and Jarvis 1928

Plate 1, Figs. 11, 12

Glomospira corona Cushman and Jarvis, 1928. Contributions from the Cushman Laboratory of Foraminiferal Research, vol. 4, p. 89, pl. 12, figs. 9-11.

Glomospira corona Cushman and Jarvis; Tappan, 1962. USGS Professional Paper 236-C, p. 130, pl. 29, figs. 13-16.

Occurrence. Tappan (1962) recognized this species in the Albian Grandstand, Topagoruk, and Fortress Mountain formations from the Arctic Slope of Alaska. In this study it is found in the lower Arctic Red Formation.

Genus Ammodiscus Reuss,1862

Ammodiscus rotalarius Loeblich and Tappan 1949

Plate 1, Figs. 13, 14

Ammodiscus rotalarius Loeblich and Tappan, 1949. Journal of Paleontology, vol. 23, p. 247, pl. 46, fig. 1.

Ammodiscus rotalarius Loeblich and Tappan; Tappan, 1962. USGS Professional Paper 236-C, p. 131, pl. 30, figs. 5-8.

Occurrence. This species is found throughout the Albian-Cenomanian Nanushuk group and underlying Torok Formation in Alaska. It is found in the lower Arctic Red formation in this study.

Family HORMOSINIDAE Haeckel, 1894

Genus Reophax de Montfort, 1808

Reophax fuscus Chamney 1978

Plate 1, Figs. 15, 16

Reophax fuscus Chamney, 1978. Geological Survey of Canada, Bulletin no. 253, p. 11, pl. 2, figs. 4-7. 
Occurrence. Chamney reports this species from the Aptian/Albian Martin House Formation and Middle Albian Arctic Red Formation. In this study it occurs the Arctic Red Formation.

Reophax incompta Loeblich and Tappan 1946

Plate 1, Figs. 17, 18

Reophax incompta Loeblich and Tappan, 1946. Journal of Paleontology, vol. 20, no. 3, p. 242 , fig. 1.

Reophax incompta Loeblich and Tappan; Chamney, 1978. Geological Survey of Canada, Bulletin no. 253, p. 11, pl. 2, figs. 1-3.

Occurrence. Chamney (1978) reports this species from the Albian Martin House and Arctic Red formations. It is found throughout the Arctic Red Formation in this study.

Reophax minuta Tappan 1940

Plate 1, Figs. 19, 20

Reophax minuta Tappan, 1940. Journal of Paleontology, vol. 14, p. 94, pl. 14, fig. 4.

Reophax minuta Tappan, 1962. USGS Professional Paper 236-C, p. 132, pl. 30, fig. 10.

Occurrence. This species is recognized in the Albian Topagoruk and Oumalik formations of the Arctic Slope of Alaska. In this study it occurs in the Arctic Red Formation.

Reophax tundraensis Chamney 1969

Plate 1, Figs. 21, 22

Reophax tundraensis Chamney, 1969. Geological Survey of Canada, Bulletin no. 185, p. 22-23, pl. 4, figs. 2-4.

Occurrence. This species was first described from rock unit 1 of the Mount Goodenough section, District of Mackenzie; Lower Cretaceous. 


\section{Reophax vasiformis Chamney 1978}

Plate 1, Figs. 23, 24

Reophax vasiformis Chamney, 1978. Geological Survey of Canada, Bulletin no. 253, p. 10-11, pl. 1, figs. 12-14.

Occurrence. Chamney (1978) recognized this species in the Albian Arctic Red Formation. In this study it occurs in the Arctic Red, Slater River, and Trevor formations.

Family RZEHAKINIDAE Cushman, 1933

Genus Psamminopelta Tappan, 1957

Psamminopelta bowsheri Tappan 1957

Plate 1, Figs. 25, 26

Psamminopelta bowsheri Tappan, 1957. United States National Museum, Bulletin no. 215, p. 211, pl. 67, figs. 11-18.

Psamminopelta bowsheri Tappan, 1962. USGS Professional Paper 236-C, p. 157, pl. 37, figs. 11-22.

Occurrence. This species is reported from the Albian Grandstand, Topagoruk, Tuktu, and upper part of the Torok formations in the Arctic Slope of Alaska. In this study it is found in the upper Arctic Red Formation.

Family LITUOLIDAE de Blainville, 1825

Genus Haplophragmoides Cushman, 1910

Haplophragmoides bonanzaense Stelck and Wall 1954

Plate 1, Figs. 27, 28

Haplophragmoides bonanzaense Stelck and Wall, 1954. Research Council of Alberta, Report no. 68, p. 24, pl. 2, fig. 10a-b.

Haplophragmoides bonanzaense Stelck and Wall; Tappan 1962. USGS Professional Paper 236-C, p. 133, pl. 30, figs. 16-19.

Occurrence. This species is described from the Turonian Central Kaskapau Formation in Alberta. It is found in the Turonian Seabee and Senonian Schrader Bluff formations in Alaska. In this study it occurs in the upper Trevor Formation. 
Haplophragmoides gigas Cushman 1927

Plate 1, Figs. 29, 30

Haplophragmoides gigas Cushman, 1927. Royal Society of Canada, Transactions ser. 3, vol. 21, p. 129, pl. 2, fig. 5.

Haplophragmoides gigas Cushman. Stelck and Koke, 1987. Canadian Journal of Earth Sciences, vol. 24, p. 2254-2278, pl. 3, figs. 5-6.

Occurrence. This species is recognized in the Upper Albian Hasler, Joli Fou, and Westgate formations in Alberta and British Columbia. It is found in lower part of the Ignek Formation in Alaska. In this study a single occurrence is found in the upper Arctic Red Formation.

Remarks. Although widely reported from Alberta, this species occurs more rarely in the north. Tappan suggested that it may be related to Haplophragmoides topagorukensis, which is more abundant in this area.

Haplophragmoides gigas minor Nauss 1947

Plate 1, Figs. 31, 32

Haplophragmoides gigas minor Nauss, 1947. Journal of Paleontology, vol. 21, p. 338, pl. 49, fig. 10.

Haplophragmoides gigas minor Nauss; Wall, 1983. Bulletin of Canadian Petroleum Geology, vol. 31, no. 4, p. 278, pl. 6, figs. 5-7.

Occurrence. This species is reported from the Early Albian Christopher Formation from the Eastern Sverdrup Basin. In the study area it is found in the lower Arctic Red Formation.

Haplophragmoides linki Nauss 1947

Plate 1, Figs. 33, 34

Haplophragmoides linki Nauss, 1947. Journal of Paleontology, vol. 21, p. 339, pl. 49, fig. $7 a-b$.

Haplophragmoides linki Nauss; McNeil and Caldwell, 1981. Geological Association of Canada, Special Paper no. 21, p. 153, pl. 11, fig. 11. 
Occurrence. This species is found in the latest Albian Westgate and Lower Cenomanian Belle Fourche Member of the Ashville Formation in Alberta. In the study area it is found in the Arctic Red Formation.

\section{Haplophragmoides peelensis Chamney 1978}

Plate 1, Figs. 35, 36

Haplophragmoides peelensis Chamney, 1978. Geological Survey of Canada, Bulletin no. 253, p. 13, pl. 3, figs. 4,5 .

Occurrence. Chamney first reported this species from the Albian Arctic Red Formation. In this study it occurs in the Arctic Red and Slater River formations.

Remarks. This species resembles H. topagorukensis but is distinguished by its scalloped edge and by having more than eight chambers in its last whorl.

\section{Haplophragmoides rota Nauss 1947}

Plate 2, Figs. 1, 2

Haplophragmoides rota Nauss, 1947. Journal of Paleontology, vol. 21, p. 339, pl. 49, figs. 1, 3.

Haplophragmoides rota Nauss; McNeil and Caldwell, 1981. Geological Association of Canada, Special Paper no. 21, p.153, pl. 11, fig. 12.

Occurrence. This species has been reported from strata ranging from Turonian to Campanian through the Western Interior. In Alaska it occurs in the Seabee and Schrader Bluff formations. In this study it is found in the Trevor Formation.

Haplophragmoides spissus Stelck and Wall 1956

Plate 2, Figs. 3, 4

Haplophragmoides spissus Stelck and Wall, 1956. Research Council of Alberta, Report no. 75, p. 39, pl. 4, figs. 27, 28.

Haplophragmoides cf. H. spissum Stelck and Wall; Chamney, 1978. Geological Survey of Canada, Bulletin no. 253, p. 14, pl. 3, fig. 8.

Occurrence. This species was originally described from the Ft. St. John shales of Middle Albian age from British Columbia. Chamney reported it from the Arctic Red Formation. In this study it is found in the Arctic Red Formation. 
Haplophragmoides topagorukensis Tappan 1957

Plate 2, Figs. 5, 6

Haplophragmoides topagorukensis Tappan, 1957. United States National Museum, Bulletin no. 215, p. 203, pl. 65, figs. 15-25.

Haplophragmoides topagorukensis Tappan, 1962. USGS Professional Paper 236-C, p.135, pl. 31, figs. 1-15.

Occurrence. This species is reported from the Albian Grandstand, Topagoruk, Torok, and Fortress Mountain formations from the Arctic Slope of Alaska. Chamney (1978) reported it from the Arctic Red Formation. It is found throughout the Arctic Red Formation in this study.

Remarks. This species when originally described by Tappan was highly variable in size and morphology. Chamney subdivided the species into three taxa, $H$.

topagorukensis, H. peelensis and H. yukonensis. H. topagorukensis is identified as small, evolute, and having approximately 8 chambers in its last whorl.

Haplophragmoides yukonensis Chamney 1978

Plate 2, Figs. 7, 8

Haplophragmoides yukonensis Chamney, 1978. Geological Survey of Canada, Bulletin no. 253, p. 13, pl. 2, figs. 8,9 .

Occurrence. Chamney (1978) originally described this species from the Albian Arctic Red Formation. In this study it is found in the Arctic Red Formation.

Remarks. This species resembles H. topagorukensis but is distinguished by having 10-14 chambers in its last whorl. In this study H. yukonensis is found lower in section than the similar H. peelensis and may be ancestral to it.

Genus Ammobaculites Cushman, 1910

Ammobaculites wenonahae Tappan 1960

Plate 2, Figs. 9, 10

Ammobaculites wenonahae Tappan, 1960. American Association of Petroleum Geologists Bulletin, vol. 44, no. 3, p. 291, pl. 1, figs. 3-6.

Ammobaculites wenonahae Tappan, 1962. USGS Professional Paper 236-C, p. 138, pl. 32, figs. 1-7. 
Occurrence. This species is originally described from the Albian Topagoruk and Grandstand formations in Alaska. It is recognized in the Arctic Red Formation in this study.

Genus Ammobaculoides Plummer, 1932

Ammobaculoides whitneyi (Cushman and Alexander) 1930.

Plate 2, Figs. 11, 12

Spiroplectammina whitneyi Cushman and Alexander, 1930. Contributions from the Cushman Laboratory of Foraminiferal Research, vol. 6, pt. 1, p. 8, pl. 2, fig. 12.

Ammobaculoides whitneyi (Cushman and Alexander); McNeil and Caldwell, 1981. Geological Association of Canada, Special Paper no. 21, p. 160, pl. 12, figs. 11, 12.

Occurrence. This species is reported from the Late Albian Skull Creek Member of the Ashville Formation. It was first reported from the Albian Goodland Formation in Texas. In the study area it occurs in the Arctic Red Formation.

Ammobaculoides sp.

Plate 2, Figs. 13, 14

Occurrence. This taxon is found in the Pseudoclavulina hastata Zone in the Trevor Formation.

Genus Ammotium Loeblich and Tappan, 1953

Ammotium lorangerae (Stelck and Wall) 1955

Plate 2, Figs. 15, 16

Ammomarginulina lorangerae Stelck and Wall, 1955. Research Council of Alberta, Report no. 70, p. 34, pl. 1, figs. 13, 27.

Ammotium lorangerae Stelck and Leckie, 1990. Canadian Journal of Earth Sciences, pl. 1, figs. 22, 23.

Occurrence. This species is described from the Upper Albian Shaftesbury Formation in the Peace River area. In this study it is found in the Trevor Formation. 
Genus Flabellammina Cushman, 1928

Flabellammina chapmani Tappan 1960

Plate 2, Figs. 17, 18

Flabellammina chapmani Tappan, 1960. American Association of Petroleum Geologists Bulletin, vol. 44, no. 3, pt. 1, p. 292, pl. 1, figs. 13, 14.

Flabellammina chapmani Tappan, 1962. USGS Professional Paper 236-C, p. 139, pl. 33, figs. 13-15.

Occurrence. This species is reported from the Turonian to Campanian Seabee and Schrader Bluff formations from the Arctic Slope of Alaska. In the study area it is found in the upper Trevor Formation.

Family TEXTULARIIDAE Ehrenberg, 1838

Genus Spiroplectammina Cushman, 1927

Spiroplectammina webberi Tappan 1957

Plate 2, Figs. 19, 20

Spiroplectammina webberi Tappan, 1957. United States National Museum, Bulletin no. 215 , p. 205 , pl. 66 , figs. $3-5$.

Spiroplectammina webberi Tappan,1962. USGS Professional Paper 236-C, p. 140, pl. 33, figs. 1-3.

Occurrence. This species occurs throughout the Upper Cretaceous Colville Group in the Alaska. It is found in the Trevor Formation in this study.

Genus Textularia Defrance, 1824

Textularia alcesensis Stelck and Wall 1958

Plate 2, Figs. 21, 22

Textularia alcesensis Stelck and Wall, 1958. Research Council of Alberta, Bulletin 2, pt. 1, p. 32, pl. 4, figs. 19-21.

Occurrence. This species was originally reported from shale 96 feet below base of massive Dunvegan sandstone bed in British Columbia thought to be Cenomanian age. One specimen was recovered from the Slater River Formation in this study. 
Textularia gravenori Stelck and Wall 1955

Plate 2, Figs. 23, 24

Textularia gravenori Stelck and Wall, 1955. Research Council of Alberta, Report no. 70 , p. 55, pl. 2, fig. 36

Textularia gravenori Stelck and Wall; Tappan, 1962. USGS Professional Paper 236-C, p. 141, pl. 33, figs. 16, 17.

Occurrence. This species is restricted to the Turonian Seabee Formation in Alaska. In this study it is found throughout the Trevor Formation.

Textularia topagorukensis Tappan 1957

Plate 2, Figs. 25, 26

Textularia topagorukensis Tappan, 1957. United States National Museum, Bulletin no. 215 , p. 305 , pl. 66 , figs. $8,9$.

Textularia topagorukensis Tappan 1962. USGS Professional Paper 236-C, p. 141, pl. 33, figs. 7-11.

Occurrence. This species is found in the Albian Torok, Topagoruk, Tuktu, and Grandstand Formations in Alaska. In this study it occurs throughout the Arctic Red Formation.

Genus Pseudobolivina Wiesner, 1931

Pseudobolivina rayi (Tappan) 1957

Plate 2, Figs. 27, 28

Siphotextularia? rayi Tappan, 1957. United States National Museum, Bulletin no. 215, p. 206, pl. 66, figs. 6, 7.

Pseudobolivina rayi (Tappan); Sliter, 1981. Geological Survey of Canada, Bulletin no. 300, p. 54, pl. 11, figs. 9-10, 22.

Occurrence. This species is reported from the Albian Christopher Formation from the Sverdrup Basin. In the study area it occurs in the lower Arctic Red Formation. 


\section{Pseudobolivina variana (Eicher) 1960}

Plate 2, Figs. 29, 30

Bimonilina variana Eicher, 1960. Peabody Museum of Natural History, Bulletin no. 15, p. 67, pl. 4, figs. 15-19.

Pseudobolivina variana (Eicher); North and Caldwell, 1975. Geological Survey of Canada, Paper 74-38, p. 14, pl. 2, figs. 19, 20.

Occurrence. This species is reported from the Albian and Cenomanian Lower Colorado Group and Ashville Formation. In the study area it is found in the Arctic Red Formation.

Family TROCHAMMINIDAE Schwager, 1877

Genus Trochammina Parker and Jones, 1859

Trochammina albertensis Wickenden 1932

Plate 2, Figs. 31-34

Trochammina albertensis Wickenden, 1932. Transactions of the Royal Society of Canada, ser. 3, vol. 26, sec. 4, p. 90, pl. 1, fig. 9a-c.

Trochammina albertensis Wickenden; McNeil and Caldwell, 1981. Geological Association of Canada, Special Paper no. 21, p. 167, pl. 13, fig. 6.

Occurrence. This species is originally described from the Campanian Bearpaw Formation in Alberta. It is reported from the Millwood Member of the Pierre Shale in Manitoba and Upper Cretaceous Schrader Bluff Formation in Alaska. In the study area this species occurs in the upper Trevor Formation.

Trochammina diagonis (Carsey) 1926

Plate 2, Figs. 35-38

Haplophragmoides diagonis Carsey, 1926. Texas University Bulletin, no. 2612, p. 22, pl. 3, fig. 1

Trochammina diagonis (Carsey); Tappan, 1962. USGS Professional Paper 236-C, p. 153, pl. 38, figs. 1-4.

Occurrence. This species is reported to range throughout the Upper Cretaceous Colville Group of Alaska. In the study area it occurs in the upper Trevor Formation. 
Trochammina rainwateri Cushman and Applin 1946

Plate 2, Figs. 39, 41

Trochammina rainwateri Cushman and Applin, 1946. Contributions from the Cushman Laboratory of Foraminiferal Research, vol. 22, p. 75, pl. 13, fig. 9.

Trochammina rainwateri Cushman and Applin; McNeil and Caldwell, 1981. Geological Association of Canada, Special Paper no. 21, p. 169, pl. 13, figs. 11, 12.

Occurrence. This species was originally described from the Cenomanian Woodbine Group of Texas. It has been reported from the Cenomanian Belle Fourche Member of the Ashville Formation from the Manitoba Escarpment and Cenomanian Kaskapau Formation of Alberta. In Alaska it has been reported from the Albian Tuktu, Topagoruk, and Grandstand and Cenomanian Ninuluk formations. In the study area it is found in the upper Trevor Formation.

Trochammina ribstonensis Wickenden 1932

Plate 3, Figs. 1-6

Trochammina ribstonensis Wickenden, 1932. Transactions of the Royal Society of Canada, ser. 3, vol. 26, sec. 4, p. 90, pl. 1, fig. 12a-c.

Trochammina ribstonensis Wickenden, McNeil and Caldwell, 1981. Geological Association of Canada, Special Paper no. 21, p. 170, pl. 14, fig. 1.

Occurrence. This species is originally described from Upper Cretaceous beds in Alberta. It is reported from the Turonian Seabee Formation in Alaska and is found widely throughout the Western Interior in Upper Cretaceous strata. In the study area this species occurs in the Trevor Formation.

Trochammina rutherfordi Stelck and Wall 1955

$$
\text { Plate 3, Figs. 7-9 }
$$

Trochammina rutherfordi Stelck and Wall, 1955. Research Council of Alberta, Report no. 70 , p. 56-57, pl. 1, figs. 11, 12 .

Trochammina rutherfordi Stelck and Wall; McNeil and Caldwell, 1981. Geological Association of Canada, Special Paper no. 21, p. 171, pl. 14, fig. 2.

Occurrence. This species was originally described from the Cenomanian-Turonian lower part of the Kaskapau Formation in Alberta. It is reported from the Westgate and Belle Fourche Members of the Ashville Formation in Manitoba and the Albian 
Grandstand and Cenomanian Ninuluk formations in Alaska. In the study area it is found in the Arctic Red and Trevor formations.

Remarks. Tappan regarded T. rutherfordi as a subspecies of $T$. ribstonensis from the Arctic Slope of Alaska, however elsewhere the species seems to be separate although may be ancestral to T. ribstonensis.

Trochammina umiatensis Tappan 1957

Plate 3, Figs. 10-12

Trochammina umiatensis Tappan, 1957. United States National Museum, Bulletin no. 215 , p. 214, pl. 67, figs. 27-29.

Trochammina umiatensis Tappan, 1962. USGS Professional Paper 236-C, p. 156, pl. 38, figs. 5-8.

Occurrence. This species is reported from the Albian Grandstand Formation in Alaska. In the study area it is found in the lower Arctic Red Formation.

Trochammina whittingtoni Tappan 1957

Plate 3, Figs. 13-15

Trochammina whittingtoni Tappan, 1957. United States National Museum, Bulletin no. 215 , p. 214, pl. 68, figs. 3-6.

Trochammina whittingtoni Tappan, 1962. USGS Professional Paper 236-C, p. 157, pl. 39, figs. 1-6.

Occurrence. This species is reported from the Upper Cretaceous Seabee and Schrader Bluff formations in Alaska. In the study area it is found in the Trevor Formation.

Family ATAXOPHRAGMIIDEA Schwager, 1877

Genus Gaudryina d'Orbigny, 1839

Gaudryina canadensis Cushman 1943

Plate 3, Figs. 16, 17

Gaudryina canadensis Cushman, 1943. Contributions from the Cushman Laboratory of Foraminiferal Research, vol. 19, pt. 2, p. 28, pl. 6, figs. 7, 8. 
Gaudryina canadensis Cushman, McNeil and Caldwell, 1981. Geological Association of Canada, Special Paper 21, p. 175, pl. 14, figs. 10, 11.

Occurrence. This species is reported from the Late Albian Skull Creek and Westgate Members of the Ashville Formation in Manitoba. In Alaska it occurs in the Albian Topagoruk and Grandstand formations and in the Cenomanian Ninuluk Formation. In the study area it is found in the upper Arctic Red Formation.

Remarks. This species is identified by one large final chamber, it is triserial becoming biserial and may be uniserial at the top. It is generally long, slender, and tapering. It may represent an intermediate evolutionary stage from Early Albian $G$. tailleuri to Late Albian $G$. canadensis to Cenomanian-Turonian G. irenensis. This species differs from Verneuilinoides borealis in lacking the characteristic bulbous chambers of $V$. borealis, and losing triserial form becoming biserial or even uniserial at the top.

Gaudryina irenensis Stelck and Wall 1955

Plate 3, Figs. 18, 19

Gaudryina irenensis Stelck and Wall, 1955. Research Council of Alberta, Report no. 68, p. 208, pl. 66, figs. 19-22

Gaudryina irenensis Cushman, McNeil and Caldwell, 1981. Geological Association of Canada, Special Paper 21, p. 177, pl. 14, figs. 8, 9.

Occurrence. This species was originally described from the Cenomanian part of the Kaskapau Formation in Alberta. It is reported from the Westage and basal Belle Fourche Members of the Ashville Formation in Manitoba, and the Ninuluk, Seabee, and Schrader Bluff formations in Alaska. In the study area it is found exclusively in the Trevor Formation.

Gaudryina nanushukensis Tappan 1951

Plate 3, Figs. 20, 21

Gaudryina nanushukensis Tappan, 1951. Contributions from the Cushman Laboratory of Foraminiferal Research, vol. 2, pt. 1, p. 2, pl. 1, figs. 8-11.

Gaudryina nanushukensis Tappan; Sliter, 1981. Geological Survey of Canada, Bulletin 300, p. 57, pl. 11, figs. 13-15, 17.

Occurrence. This species is reported from the Albian Grandstand, Topagoruk, Torok, and Tuktu formations in Alaska. In the study area it is found in the lower Arctic Red Formation. 


\section{Gaudryina stotti Chamney 1978}

Plate 3, Figs. 22, 23

Gaudryina stotti Chamney, 1978. Geological Survey of Canada, Bulletin no. 253, p. 20, pl. 4, figs. 6-8.

Occurrence. Chamney originally described this species from the Middle Albian part of the Arctic Red Formation. In the study area it is found in the Late Albian upper Arctic Red Formation.

Remarks. This species is identified by being short, rapidly flaring, subangular, with slightly excavated sides. This taxon might be related to $G$. nanushukensis but occurs higher in section.

\section{Gaudryina tailleuri (Tappan) 1957}

\section{Plate 3, Figs. 24, 25}

Verneuilinoides tailleuri Tappan, 1957. United States National Museum, Bulletin no. 215, p. 208, pl. 66, figs. 19-22.

Gaudryina tailleuri (Tappan) 1962. USGS Professional Paper 236-C, p. 149, pl. 35, figs. 8-16.

Occurrence. This species is reported from the Torok and Fortress Mountain formations in Alaska. In the study area it occurs in the Arctic Red Formation.

Remarks. This species resembles $G$. canadensis but is distinguished by its nearly parallel sides and is generally slightly rounder, shorter, and less flaring.

Genus Tritaxia Reuss, 1860

Tritaxia solea Chamney 1978

Plate 3, Figs. 26-28

Tritaxia solea Chamney, 1978. Geological Survey of Canada, Bulletin no. 253, p. 15, pl. 3, figs. 19-21.

Occurrence. Chamney originally described this species from the Arctic Red Formation. In the study area it occurs in the lower Arctic Red Formation. 


\section{Tritaxia sp.}

Plate 3, Figs. 29, 30

Occurrence. This species occurs in the Gaudryina irenensis and Pseudoclavulina hastata zones in the Trevor Formation.

Genus Uvigerinammina Majzon, 1943

Uvigerinammina manitobensis (Wickenden) 1932

Plate 3, Figs. 31, 32

Tritaxia manitobensis Wickenden, 1932. Transactions of the Royal Society of Canada, ser. 3, vol. 26, sec. 4, p. 87-88, pl. 1, fig. 10.

Uvigerinammina manitobensis (Wickenden); McNeil and Caldwell, 1981. Geological Association of Canada, Special Paper no. 21, p. 179, pl. 14, figs. 15-18.

Occurrence. This species was originally described from the Albian-Cenomanian Ashville Formation of Manitoba and has been reported from the Albian Tuktu, Topagoruk, and Grandstand formations in Alaska. In the study area it occurs in the lower Arctic Red Formation.

Genus Verneuilinoides Loeblich and Tappan, 1949

Verneuilinoides canadensis (Cushman) 1927

Plate 3, Figs. 33, 34

Verneuilina canadensis Cushman, 1927. Transactions of the Royal Society of Canada, ser. 3, vol. 21, sec. 4, p. 131, pl. 1, fig. 11.

Verneuilina canadensis Cushman; McNeil and Caldwell, 1981. Geological Association of Canada, Special Paper no. 21, p. 175, pl. 14, fig. 3.

Occurrence. This species has been reported from the Westgate Member of the Ashville Formation in Manitoba, the Albian Shaftesbury Formation in Alberta, and Lower Colorado Group of Saskatchewan. In the study area it occurs in the Arctic Red Formation.

Remarks. This species was originally put in the genus Verneuilina, however it is not tricarnate and has rounded edges, and so it is more appropriate to classify it in the genus Verneuilinoides. This species resembles $V$. borealis, however does not have the distinctive twisted form of that species. 
Verneuilinoides perplexus (Loeblich) 1946

Plate 4, Figs. 1, 2

Verneuilina perplexa Loeblich 1946. Journal of Paleontology, vol. 20, p. 138, pl. 22, figs. 14-16.

Verneuilinoides perplexus (Loeblich); McNeil and Caldwell, 1981. Geological Association of Canada, Special Paper no. 21, p. 180, pl. 14, figs. 19-21.

Occurrence. This species is originally described from the Cenomanian Pepper Shale of Texas. It has been reported from the Belle Fourche Member of the Ashville Formation of Manitoba and Belle Fourche Formation in Alberta. In the study area it occurs in the upper Trevor Formation extending its range into the Turonian.

Genus Arenobulimina Cushman, 1927

Arenobulimina paynei Tappan 1957

Plate 4, Figs. 3, 4

Arenobulimina paynei Tappan, 1957. United States National Museum, Bulletin no. 215 , p. 208, pl. 67, figs. 1-4

Arenobulimina paynei Tappan, 1962. USGS Professional Paper 236-C, p. 151, pl. 36, figs. 1-4.

Occurrence. This species is reported from the Grandstand and Topagoruk formations from Alaska. In the study area it occurs in the Arctic Red, Slater River, and Trevor formations.

Genus Pseudoclavulina Cushman, 1936

Pseudoclavulina hastata (Cushman) 1927

Plate 4, Figs. 5, 6

Bigenerina hastata Cushman, 1927. Transactions of the Royal Society of Canada, ser. 3, vol. 21, pt. 2, sect. 4, p. 131, pl. 1, fig. 9.

Pseudoclavulina hastata (Cushman); Tappan, 1962. USGS Professional Paper 236-C, p. 151, pl. 36, figs. 10, 11.

Occurrence. This species is reported from the Ayiyak member of the Upper Cretaceous Seabee Formation in Alaska. In the study area it occurs in the upper Trevor Formation. 


\section{Calcareous Foraminifera}

Family NODOSARIIDAE Ehrenberg, 1838

Genus Dentalina Risso, 1826

Dentalina dettermani Tappan 1957

Plate 4, Figs. 7, 8

Dentalina? dettermani Tappan, 1957. United States National Museum, Bulletin no. 215, p. 215, pl. 68, figs. 9-12.

Dentalina dettermani Tappan, 1962. USGS Professional Paper 236-C, p. 175, pl. 45, figs. 9-12, 22.

Occurrence. The species is reported from the Albian Grandstand, Topagoruk, and Fortress Mountain formations in Alaska. In the study area it is found in the Arctic Red Formation.

Genus Saracenaria Defrance, 1824

Saracenaria projectura Stelck and Wall 1956

Plate 4, Figs. 9, 10

Saracenaria projectura Stelck and Wall, 1956. Research Council of Alberta, Report no. 75 , p. 50, pl. 3, figs. 22-25.

Saracenaria projectura Stelck and Wall; Tappan, 1962. USGS Professional Paper 236C, p. 164, pl. 41, figs. 9-14.

Occurrence. This species is originally described from the Clearwater Formation in Alberta. It has been reported from the Grandstand, Topagoruk, Torok, and Fortress Mountain formations in Alaska and Christopher Formation from the Sverdrup Basin. In the study area is occurs in the lower Arctic Red Formation.

Family GLANDULININAE Reuss, 1860

Genus Oolina d'Orbigny, 1839

Oolina apiculata Reuss 1851

Plate 4, Figs. 11, 12

Oolina apiculata Reuss, 1851. Haidinger's Nat. Abh., vol. 4, p. 22, pl. 1, fig. 1. 
Oolina apiculata Reuss; Tappan, 1962. USGS Professional Paper 236-C, p. 182, pl. 47, fig. 6.

Occurrence. This species is reported from the Topagoruk Formation in Alaska. In this study it is found in the lower Arctic Red Formation.

Oolina sp.

Plate 4, Figs. 13, 14

Occurrence. This species is found in the Slater River and Trevor formations.

Family DISCORBACEA Ehrenberg, 1838

Genus Valvulineria Cushman, 1926

Valvulineria loetterli (Tappan) 1940

Plate 4, Figs. 15, 16

Gyroidina loetterli Tappan, 1940. Journal of Paleontology, vol. 14, p. 120, pl. 19, fig. 10.

Valvulineria loetterli (Tappan) 1962. USGS Professional Paper 236-C, p. 194, pl. 54, figs. 1-4.

Occurrence. This species is originally described from the lower Cenomanian Grayson Formation of Texas. It is reported from the Spirit River, Loon River, Moosebar, and Clearwater formations of Alberta and British Columbia; and Grandstand, Topagoruk, and Torok formations in Alaska. In the study area it occurs in the Arctic Red Formation.

Family NONIONIDAE Schultze, 1854

Genus Quadrimorphina Finlay, 1939

Quadrimorphina albertensis Mellon and Wall 1956

Plate 4, Figs. 17, 18

Quadrimorphina albertensis Mellon and Wall, 1956. Research Council of Alberta, Report no. 72, p. 24, pl. 2, figs. 12-14.

Quadrimorphina albertensis Mellon and Wall; Wall, 1983. Bulletin of Canadian Petroleum Geology, vol. 31, no. 4, p. 278, pl. 6, figs. 28-30. 
Occurrence. This species is reported from the Christopher Formation of the Sverdrup Basin. It occurs in the lower Arctic Red Formation in this study.

Family ANOMALINIDAE Cushman, 1927

Genus Anomalinoides Brotzen, 1942

Anomalinoides sp.

Plate 4, Figs. 19, 20

Occurrence. This species occurs in the Quadrimorphina albertensis Zone of the Arctic Red Formation in this study.

Genus Gavelinella Brotzen, 1942

Gavelinella awunensis Tappan 1960

Plate 4, Figs. 21, 22

Gavelinella awunensis Tappan, 1960. American Association of Petroleum Geologists Bulletin, vol. 44, no. 3, pt. 1, p. 296, pl. 2, figs. 15, 16.

Gavelinella awunensis Tappan, 1962. USGS Professional Paper 236-C, p. 197, pl. 56, figs. 1-7.

Occurrence. This species is reported from the Albian Torok and Topagoruk formations from the Arctic Slope of Alaska. In the study area it occurs in the lower Arctic Red Formation. 


\section{REFERENCES}

Abercrombie, H.J., Hutcheon, I.E., Bloch, J., and Caritat, P., 1994, Silica activity and the smectite-illite reaction: Geology, v. 22, p. 539-542.

Bergquist, H.R., 1958a, Micropaleontologic study of the Umiat field, Northern Alaska, in Collins, F.R., ed., Test wells, Umiat area, Alaska, United States Geological Survey, Professional Paper 305-B, p. 199-204.

-, 1958b, Micropaleontological study of the Gubik test wells, Northern Alaska, in Robinson, F.M., ed., Test wells, Gubik area, Alaska, United States Geological Survey, Professional Paper 305-C, p. 259-261.

-, 1966, Micropaleontology of the Mesozoic Rocks of Northern Alaska, United States Geological Survey, Professional Paper 302-D, p. 93-227.

Bernhard, J.M., 1986, Characteristic assemblages and morphologies of benthic foraminifera from anoxic organic-rich deposits: Jurassic through Holocene: Journal of Foraminiferal Research, v. 16, p. 207-215.

Bloch, J., Schröder-Adams, C.J., Leckie, D.A., McIntyre, D.J., Craig, J., and Staniland, M., 1993, Revised stratigraphy of the lower Colorado Group (Albian to Turonian), Western Canada: Bulletin of Canadian Petroleum Geology, v. 41, p. 325-348.

Caldwell, W.G.E., Diner, R., Eicher, D.L., Fowler, S.P., North, B.R., Stelck, C.R., and von Holt Wilhem, L., 1993, Foraminiferal Biostratigraphy of Cretaceous Marine Cyclothems, in Caldwell, W.G.E., and Kauffman, E.G., eds., Evolution of the Western Interior Basin, Geological Association of Canada, Special Paper 39, p. 477-520.

Caldwell, W.G.E., North, B.R., Stelck, C.R., and Wall, J.H., 1978, A Foraminiferal Zonal Scheme for the Cretaceous System in the Interior Plains of Canada, Geological Association of Canada, Special Paper 18, p. 495-573.

Carsey, D.O., 1926, Foraminifera of the Cretaceous of Central Texas, Texas University, Bulletin 2612, p. 1-56.

Chamney, E.W., 1969, Barremanian Textulariina, Foraminiferida from Lower Cretaceous beds, Mount Goodenough section, Aklavik Range, District of Mackenzie, Geological Survey of Canada Bulletin no. 185, p. 22-23. 
Chamney, T.P., 1978, Albian Foraminifera of the Yukon Territory, Geological Survey of Canada, Bulletin 253, p. 1-62.

Cook, D.G., 1975, The Keele Arch - A pre-Devonian and pre-Late Cretaceous paleoupland in the Northern Franklin Mountains and Colville Hills, Geological Survey of Canada, Paper 75-1, p. 243-246.

Cushman, J.A., 1927, Some Foraminifera from the Cretaceous of Canada, Transactions of the Royal Society of Canada, ser. 3, vol. 21, no. 4, p. 127-132.

-, 1943, Gaudryina canadensis, new name: Cushman Laboratory of Foraminiferal Research v. 19, p. 27-28.

Cushman, J.A., and Alexander, C.I., 1930, Some Vaginulinas and Other Foraminifera from the Lower Cretaceous of Texas, Contributions from the Cushman Laboratory for Foraminiferal Research, vol. 6, pt. 1, no. 8, p. 8.

Cushman, J.A., and Applin, E.R., 1946, Some foraminifera of Woodbine age from Texas, Mississippi, Alabama, and Georgia: Contributions from the Cushman Laboratory of Foraminiferal Research, v. 22, p. 75.

Cushman, J.A., and Jarvis, P.W., 1928, Cretaceous foraminifera from Trinidad: Contributions from the Cushman Laboratory of Foraminiferal Research, v. 4, p. 89.

Dixon, J., 1993, Regional Unconformities in the Cretaceous of North-West Canada: Cretaceous Research, v. 14, p. 19-38.

-, 1999, Mesozoic-Cenozoic Stratigraphy of the Northern Interior Plains and Plateaux, Northwest Territories, Geological Survey of Canada, Bulletin 536, p. $1-56$.

-, 2004, Lower Cretaceous (Albian) to Tertiary strata, Yukon Territory-Northwest Territories, Geological Survey of Canada Open File 4633, p. 1-26.

Dixon, J., and McNeil, D.H., 2008, Upper Cretaceous and Tertiary Stratigraphy on the Tuktoyaktuk Peninsula, Northwest Territories: Geological Survey of Canada Open File 5703, p. 1-24.

Eder, V., Martin-Algarra, A., Sanchez-Navas, A., Zanin, Y., Zamirailova, A., and Lebedev, Y., 2007, Depositional controls on glaucony texture and composition, Upper Jurassic, West Siberian Basin: Sedimentology, v. 54, p. 1365-1387.

Eicher, D.L., 1960, Stratigraphy and micropaleontology of the Thermopolis Shale: Peabody Museum of Natural History Bulletin, p. 55, 67. 
Embry, A.F., and Dixon, J., 1990, The breakup unconformity of the Amerasia Basin, Arctic Ocean: Evidence from Arctic Canada: Geological Society of America Bulletin, v. 102, p. 1526-1534.

Hadlari, T., Thomson, D., Schröder-Adams, C.J., Lemieux, Y., MacLean, B.C., and Gal, L., 2009, Chapter 9 - Cretaceous strata and basal Cretaceous sandstone play, in Pyle, L.J., and Jones, A.L., eds., Regional geoscience studies and petroleum potential, Peel Plateau and Plain: Project Volume NWT Open File 2009-02, p. 410-476.

Haq, B.U., and Al-Qahtani, A.M., 2005, Phanerozoic cycles of sea-level change on the Arabian Platform: Geoarabia, v. 10, p. 127-160.

Hesse, R., 1990, Early diagenetic pore water/sediment interaction: Modern offshore basins, in Mcllreath, I.A., and Morrow, D.W., eds., Diagenesis, Reprint Series 4, Geoscience Canada, p. 277-316.

Jowett, D., 2004, Paleoenvironments and regional correlations of AlbianCenomanian strata in the frontier Liard Basin of northwestern Canada, unpublished Ph.D. thesis, Carleton University.

Koch, J.T., and Brenner, R.L., 2009, Evidence for glacioeustatic control of large, rapid sea-level fluctuations during the Albian-Cenomanian: Dakota Formation, eastern margin of Western Interior Seaway, USA: Cretaceous Research, v. 30, p. $411-423$.

Kreitner, M., and Plint, G., 2006, Allostratigraphy and paleogeography of the Upper Cenomanian, Lower Kaskapau Formation in subsurface and outcrop, Alberta and British Columbia: Bulletin of Canadian Petroleum Geology, v. 54, p. 110137.

Kuhnt, W., 1992, Abyssal recolonization by benthic foraminifera after the Cenomanian/Turonian boundary anoxic event in the North Atlantic: Marine Micropaleontology, v. 19, p. 257-274.

Leckie, D.A., Schroder-Adams, C.J., and Bloch, J., 2000, The effect of paleotopography on the Late Albian and Cenomanian sea-level record of the Canadian Cretaceous interior seaway Geological Society of America Bulletin, v. 112, p. 1179-1198.

Loeblich, A.R., 1946, Foraminifera from the type Pepper Shale of Texas: Journal of Paleontology, v. 20, p. 138.

Loeblich, A.R., and Tappan, H., 1946, New Washita Foraminifera: Journal of Paleontology, v. 20, p. 242. 
- 1949 , Foraminifera from the Walnut Formation (lower Cretaceous) of Northern Texas and Southern Oklahoma: Journal of Paleontology, v. 23, p. 46.

—, 1950, Foraminifera from the type Kiowa shale, Lower Cretaceous, of Kansas, University of Kansas Paleontology Contributions, Protozoa, art. 3, p. 5.

—, 1964, Treatise on Invertebrate Paleontology: Part C, Protista 2, Sarcondina, Chiefly the "Thecamoebians" and Foraminiferida, Geological Society of America.

McNeil, D.H., 1996, Distribution of Albian to Maastrichtian Benthic Foraminifers in the Beaufort-Mackenzie Area, in Dixon, J., ed., Geological Atlas of the Beaufort-Mackenzie Area, Geological Survey of Canada, Miscellaneous Report 59, p. 104-105.

-, 1997a, Diagenetic regimes and the foraminiferal record in the BeaufortMackenzie Basin and adjacent cratonic areas: Annales Societatis Geologorum Poloniae, v. 67, p. 271-286.

-, 1997b, New foraminifera from the Upper Cretaceous and Cenozoic of the Beaufort-Mackenzie Basin of Arctic Canada, Cushman Foundation for Foraminiferal Research Special Publication No. 35, p. 1-94.

—, 2007, Micropaleontology Report on 13 Outcrop Samples from the Peel Plateau Area, Northwest Territories (NTS 106F, G. H), Geological Survey of Canada, Paleontological Report Number 02-DHM-2007, p. 1-5.

McNeil, D.H., and Caldwell, W.G.E., 1981, Cretaceous Rocks and Their Foraminifera in the Manitoba Escarpment, Geological Association of Canada, Special Paper 21, p. 1-439.

Mellon, G.B., and Wall, J.H., 1956a, Geology of the McMurray Foraminifera, Research Council of Alberta, Report No. 72.

—, 1956b, Geology of the McMurray Foraminifera, Research Council of Alberta, Report No. 72, p. 1-29.

Mountjoy, E.W., and Chamney, T.P., 1969, Lower Cretaceous (Albian) of the Yukon: Stratigraphy and Foraminiferal Subdivisions, Snake and Peel rivers, Geological Survey of Canada, Paper 68-26, p. 1-71.

Mücke, A., and Farshad, F., 2005, Whole-rock and mineralogical composition of Phanerozoic ooidal ironstones: Comparison and differentiation of types and subtypes: Ore Geology Reviews, v. 26, p. 227-262. 
Murray, J., and Alve, E., 1999, Natural dissolution of modern shallow water benthic foraminifera: taphonomic effects on the palaeoecological record:

Palaeogeography, Palaeoclimatology, Palaeoecology, v. 146, p. 195-209.

Nauss, A.W., 1947, Cretaceous microfossils of the Vermilion area, Alberta: Journal of Paleontology, v. 21, p. 338-339.

North, B.R., and Caldwell, W.G.E., 1975, Illustrations of Canadian Fossils: Cretaceous foraminifera from Saskatchewan and Manitoba, Geological Survey of Canada Paper 74-38, p. 14.

Pattison, S., and Walker, R., 1994, Incision and filling of a lowstand valley: Late Albian Viking Formation at Crystal, Alberta, Canada: Journal of Sedimentary Research, v. B64, p. 365-379.

Pemberton, S.G., Spila, M., Pulham, A.J., Saunders, T., MacEachran, J.A., Robbins, D., and Sinclair, I.K., 2001, Ichnology and sedimentology of shallow to marginal marine systems: Ben Nevis and Avalon Reservoirs, Jeanne D'Arc Basin, Geological Association of Canada Short Course Volume 15, p. 1-343.

Pyle, L.J., and Jones, A.L., 2009, Regional geoscience studies and petroleum potential, Peel Plateau and Plain, Northwest Territories and Yukon: Project Volume, NWT Open File 2009-02, p. 1-549.

Reuss, A.E., 1851, Die Foraminiferen und Entomostraceen des Kreidemergels von Lemberg: Haidinger's Naturw. Abh., Wein,, v. 4, p. 17-52.

Sahagian, D., Pinous, O., Olferiev, A., and Zakharov, V., 1996, Eustatic curve for the Middle Jurassic-Cretaceous based on Russion Platform and Siberian stratigraphy; zonal resolution: American Association of Petroleum Geologists Bulletin, v. 80, p. 1433-1458.

Schröder-Adams, C.J., Cumbaa, S., Bloch, J., Leckie, D.A., Craig, J., El-Dein, S., Simons, D., and Kenig, F., 2001, Late Cretaceous (Cenomanian to Campanian) paleoenvironmental history of the Eastern Canadian margin of the Western Interior Seaway: bonebeds and anoxic events: Palaeogeography, Palaeoclimatology, Palaeoecology, v. 170, p. 261-289.

Schröder-Adams, C.J., Leckie, D.A., Bloch, J., Craig, J., McIntyre, D.J., and Adams, P.J., 1996, Paleoenvironmental Changes in the Cretaceous (Albian to Turonian) Colorado Group of Western Canada: Microfossil, Sedimentological and Geochemical Evidence: Cretaceous Research, v. 17, p. 311-365.

Schröder-Adams, C.J., and McNeil, D.H., 1994, Oligocene to Miocene agglutinated foraminifera in deltaic and deep water facies of the Beaufort-Mackenzie Basin, Geological Survey of Canada Bulletin 477, p. 1-75. 
Sliter, W.V., 1981, Albian Foraminifers from the Lower Cretaceous Christopher Formation of the Canadian Arctic Islands, Geological Survey of Canada, Bulletin 300, p. 41-70.

Stelck, C.R., and Koke, K.R., 1987, Foraminiferal zonation of the Viking interval in the Hasler Shale (Albian), northeastern British Columbia: Canadian Journal of Earth Sciences, v. 24, p. 2254-2278.

Stelck, C.R., and Leckie, D.A., 1990, Biostratigraphy of the Albian Paddy Member (Lower Cretaceous Peace River Formation), Goodfare, Alberta: Canadian Journal of Earth Science, v. 27, p. 1159-1169.

Stelck, C.R., and Wall, J.H., 1954, Kaskapau Foraminifera from Peace River Area of Western Canada, Research Council of Alberta, Report 68, p. 1-37.

-, 1955, Foraminifera of the Cenomanian Dunveganoceras Zone from Peace River Area of Western Canada, Research Council of Alberta, Report 70, p. 1-62.

—, 1956, Middle Albian Foraminifera from Athabasca and Peace River Drainage Areas of Western Canada, Research Council of Alberta, Report No. 75.

—, 1958, Lower Cenomanian foraminifera from Peace River area, Western Canada, Research Council of Alberta, Bulletin 2, pt. 1, p. 32.

Tappan, H., 1940, Foraminifera from the Grayson Formation of Northern Texas: Journal Paleontology, v. 14, p. 93-126.

-, 1951, Northern Alaska index foraminifera: Contributions from the Cushman Laboratory of Foraminiferal Research, v. 2, pt. 1, p. 2.

-, 1957, New Cretaceous Index Foraminifera from Northern Alaska, Volume United States National Museum, Bulletin 215, p. 201-222.

-, 1960, Cretaceous biostratigraphy of Northern Alaska: American Association of Petroleum Geologists Bulletin, v. 44, p. 289, 291-292, 296.

-, 1962, Foraminifera from the Arctic Slope of Alaska, United States Geological Survey, Professional Paper 236-C, p. 91-209, plates 29-58.

Tassonyi, E.J., 1969, Subsurface geology, lower Mackenzie River and Anderson River area. District of Mackenzie, Geological Survey of Canada, Paper 68-25, p. 1207.

Then, D.R., and Dougherty, B.J., 1983, A new procedure for extracting foraminifera from indurated organic shale, Geological Survey of Canada, vol. 83-1B, p. 413414. 
Walker, R., and Plint, G., 1992, Wave- and storm-dominated shallow marine systems, in Walker, R., and James, N., eds., Facies models: Response to sea level change, Geological Association of Canada.

Wall, J.H., 1983, Jurassic and Cretaceous Foraminiferal Biostratigraphy in the Eastern Sverdrup Basin, Canadian Arctic Archipelago: Bulletin of Canadian Petroleum Geology, v. 31, p. 246-281.

Wickenden, R., 1932, New species of foraminifera from the Upper Cretaceous of the prairie provinces: Transactions of the Royal Society of Canada, ser. 3, v. 26, sect. 4, p. 87-88, 90.

Williams, G.D., and Stelck, C.R., 1975, Speculations on the Cretaceous paleogeography of North America, in Caldwell, W.G.E., ed., The Cretaceous system in the Western Interior of North America, Geological Association of Canada, Special Paper Number 13, p. 1-20.

Williams, G.K., 1989, Tectonic evolution of the Fort Norman area, Mackenzie Corridor, N.W.T., Geological Survey of Canada, Open File 2045, p. 98 p.

Yorath, C.J., and Cook, D.G., 1981, Cretaceous and Tertiary Stratigraphy and Paleogeography, Northern Interior Plains, District of Mackenzie, Geological Survey of Canada, Memoir 398, p. 76 p.

Young, T.P., 1989, Introduction and review, in Young, T.P., and Taylor, W.E.G., eds., Phanerozoic Ironstones, Volume 46, Geological Society Special Publications, p. ix-xxv. 
PLATES 


\section{Plate 1}

\section{AGGLUTINATED FORAMINIFERA}

Figs. 1-2. Bathysiphon brosgei Tappan 1957. Sample 07-Peel-99, lower Trevor Formation, Gaudryina irenensis Zone.

Figs. 3-4. Bathysiphon emacerata Chamney 1978. Sample 07-Peel-72, lower Trevor Formation, Gaudryina irenensis Zone.

Figs. 5-6. Bathysiphon strombotubulare Chamney 1978. Sample 07-Peel-92, lower Trevor Formation, Gaudryina irenensis Zone.

Figs. 7-8. Saccammina alexanderi (Leoblich and Tappan) 1950. Sample 07-Peel-26, lower Arctic Red Formation, Quadrimorphina albertensis Zone.

Figs. 9-10. Saccammina lathrami Tappan 1960. Sample 07-Peel-108, upper Trevor Formation, Gaudryina irenensis Zone.

Figs. 11-12. Glomospira corona Cushman and Jarvis 1928. Spiral view. Sample 07Peel-21, lower Arctic Red Formation, Quadrimorphina albertensis Zone.

Figs. 13-14. Ammodiscus rotalarius Loeblich and Tappan 1949. Sample 07-Peel-12, lower Arctic Red Formation, Quadrimorphina albertensis Zone.

Figs. 15-16. Reophax fuscus Chamney 1978. Sample 07-Peel-38, upper Arctic Red Formation, Gaudryina canadensis Zone.

Figs. 17-18. Reophax incompta Loeblich and Tappan 1946. Sample 07-Peel-37, upper Arctic Red Formation, Gaudryina canadensis Zone.

Figs. 19-20. Reophax minuta Tappan 1940. Sample 07-Peel-32, upper Arctic Red Formation, Gaudryina canadensis Zone.

Figs. 21-22. Reophax tundraensis Chamney 1969. Sample 07-Peel-100, upper Trevor Formation, Gaudryina irenensis Zone.

Figs. 23-24. Reophax vasiformis Chamney 1978. Sample 07-Peel-39, upper Arctic Red Formation, Gaudryina canadensis Zone.

Figs. 25-26. Psamminopelta bowsheri Tappan 1957. Sample 07-Peel-38, upper Arctic Red Formation, Gaudryina canadensis Zone.

Figs. 27-28. Haplophragmoides bonanzaense Stelck and Wall 1954. Sample 07-Peel117, upper Trevor Formation, Pseudoclavulina hastata Zone.

Figs. 29-30. Haplophragmoides gigas Cushman 1927. Sample 07-Peel-37, upper Arctic Red Formation, Gaudryina canadensis Zone. 
Figs. 31-32. Haplophragmoides gigas minor Nauss 1947. Sample 07-Peel-10, lower Arctic Red Formation, Quadrimorphina albertensis Zone.

Figs. 33-34. Haplophragmoides linki Nauss 1947. Sample 07-Peel-13, lower Arctic Red Formation, Quadrimorphina albertensis Zone.

Figs. 35-36. Haplophragmoides peelensis Chamney 1978. Sample 07-Peel-37, upper Arctic Red Formation, Gaudryina canadensis Zone. 


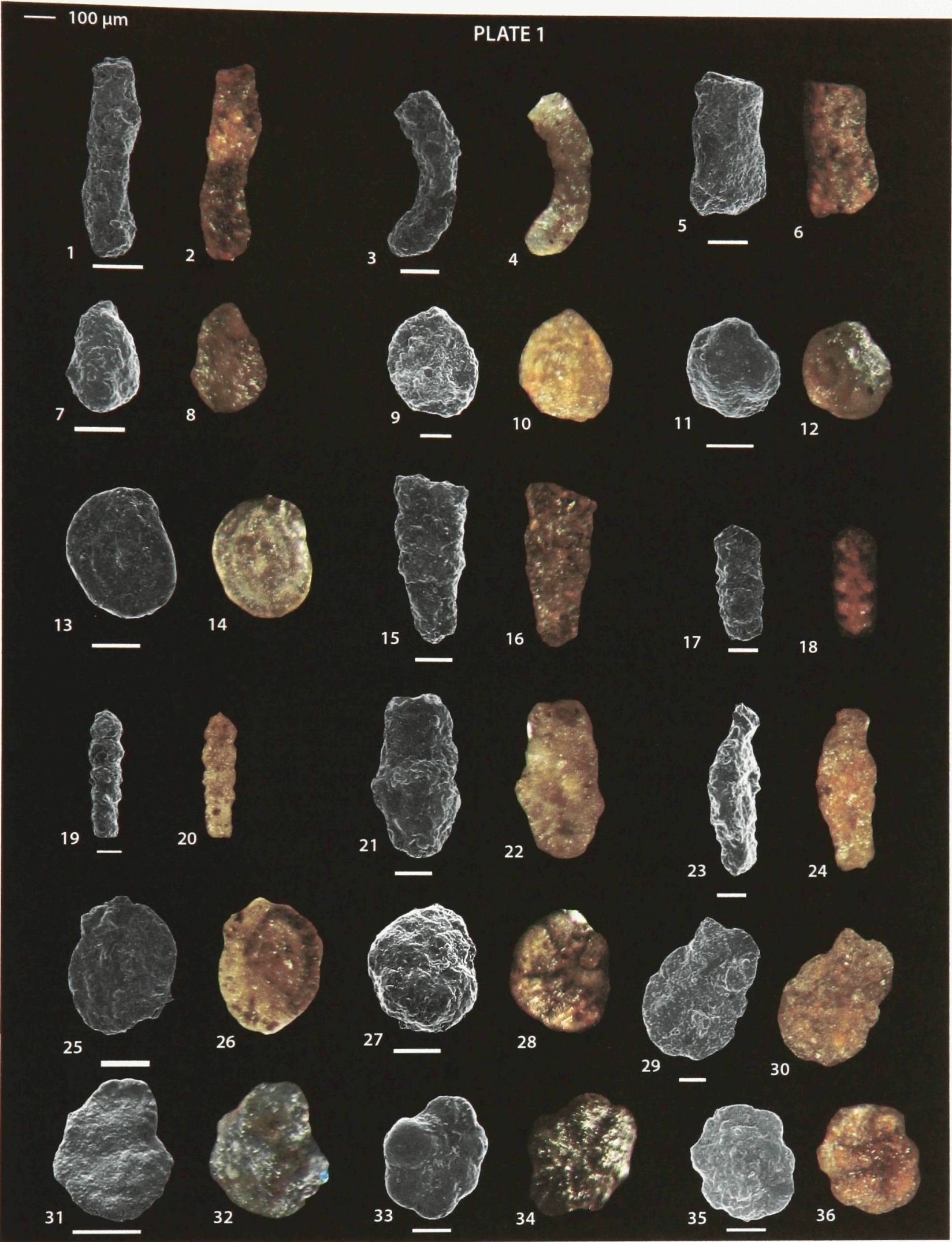




\section{Plate 2}

Figs. 1-2. Haplophragmoides rota Nauss 1947. Sample 07-Peel-113, upper Trevor Formation, Pseudoclavulina hastata Zone.

Figs. 3-4. Haplophragmoides spissus Stelck and Wall 1956. Sample 07-Peel-28, upper Arctic Red Formation, Gaudryina canadensis Zone.

Figs. 5-6. Haplophragmoides topagorukensis Tappan 1957. Sample 07-Peel-22, lower Arctic Red Formation, Quadrimorphina albertensis Zone.

Figs. 7-8. Haplophragmoides yukonensis Chamney 1978. Sample 07-Peel-26, lower Arctic Red Formation, Quadrimorphina albertensis Zone.

Figs. 9-10. Ammobaculites wenonahae Tappan 1960. Sample 07-Peel-08, lower Arctic Red Formation, Quadrimorphina albertensis Zone.

Figs. 11-12. Ammobaculoides whitneyi (Cushman and Alexander) 1930. Sample 07Peel-38, upper Arctic Red Formation, Gaudryina canadensis Zone.

Figs. 13-14. Ammobaculoides sp. Sample 07-Peel-116, upper Trevor Formation, Pseudoclavulina hastata Zone.

Figs. 15-16. Ammotium lorangerae (Stelck and Wall) 1955. Sample 07-Peel-102, upper Trevor Formation, Gaudryina irenensis Zone.

Figs. 17-18. Flabellammina chapmani Tappan 1960. Sample 07-Peel-101, upper Trevor Formation, Gaudryina irenensis Zone.

Figs. 19-20. Spiroplectammina webberi Tappan 1957. Sample 07-Peel-100, upper Trevor Formation, Gaudryina irenensis Zone.

Figs. 21-22. Textularia alcesensis Stelck and Wall 1958. Sample 07-Peel-54, Slater River Formation, Fish Marker Zone.

Figs. 23-24. Textularia gravenori Stelck and Wall 1955. Sample 07-Peel-108, lower Trevor Formation, Gaudryina irenensis Zone.

Figs. 25-26. Textularia topagorukensis Tappan 1957. Sample 07-Peel-28, upper Arctic Red Formation, Gaudryina canadensis Zone.

Figs. 27-28. Pseudobolivina rayi (Tappan) 1957. Sample 07-Peel-05, lower Arctic Red Formation, Quadrimorphina albertensis Zone.

Figs. 29-30. Pseudobolivina variana (Eicher) 1960. Sample 07-Peel-28, upper Arctic Red Formation, Gaudryina canadensis Zone.

Figs. 31-34. Trochammina albertensis Wickenden 1932. Figures 32 and 34, spiral view; figures 31 and 33, umbilical view. Sample 07-Peel-116, upper Trevor Formation, Pseudoclavulina hastata Zone. 
Figs. 35-38. Trochammina diagonis (Carsey) 1926. Figures 35 and 38, spiral view; figure 36, umbilical view; figure 37, aperture view. Sample 07-Peel-116, upper Trevor Formation, Pseudoclavulina hastata Zone.

Figs. 39-40. Trochammina rainwateri Cushman and Applin 1946. Figure 39, spiral view; figure 40, umbilical view. Sample 07-Peel-116, upper Trevor Formation, Pseudoclavulina hastata Zone. 
$-100 \mu \mathrm{m}$
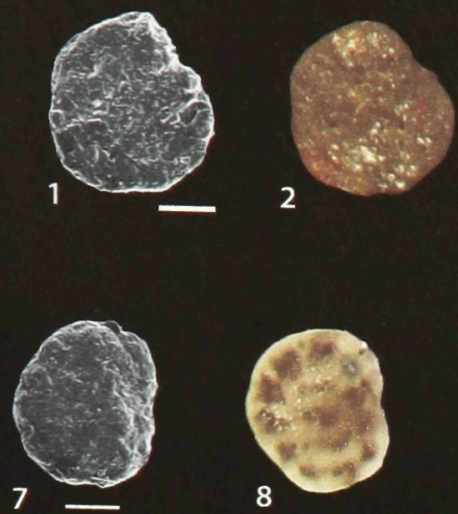

13

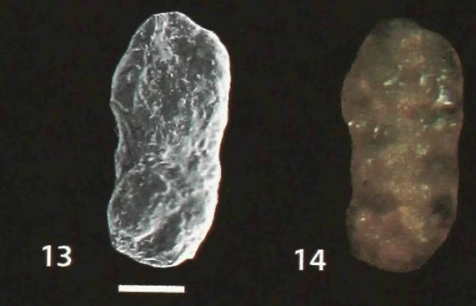

\section{PLATE 2}
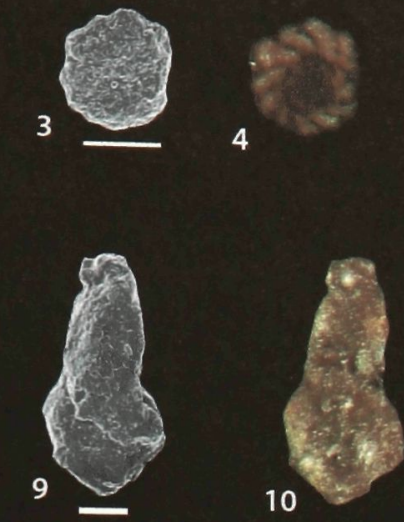
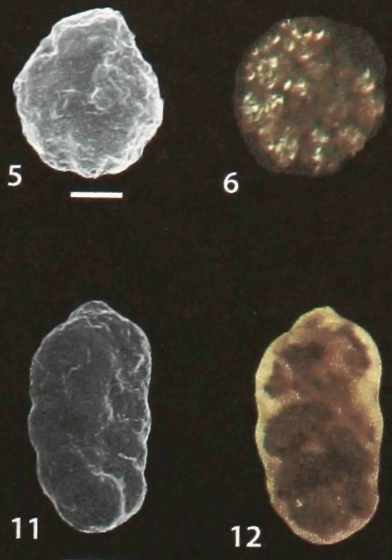
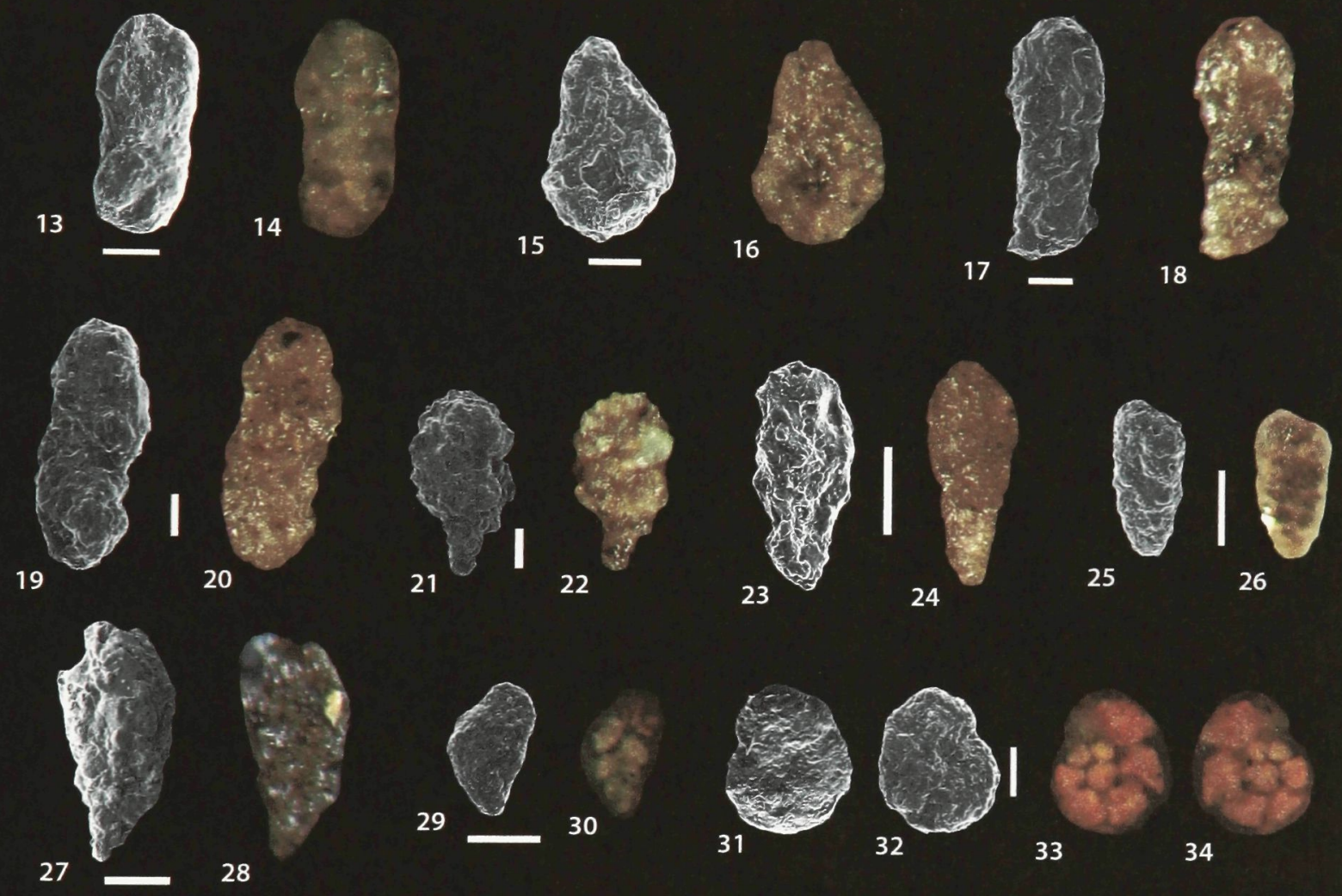

33

34
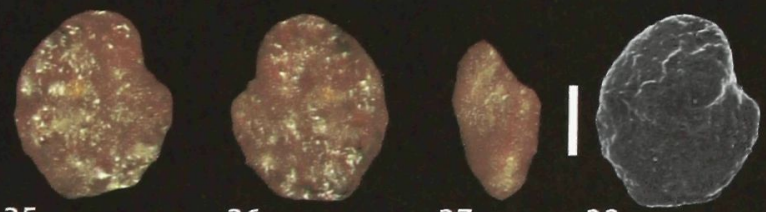

37

38

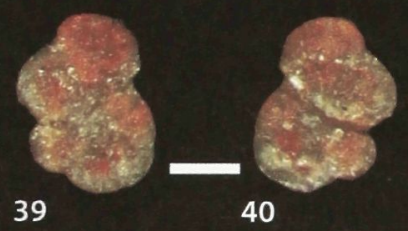




\section{Plate 3}

Figs. 1-6. Trochammina ribstonensis Wickenden 1932. Figures 1 and 3, spiral view; figure 2, umbilical view; sample 07-Peel-112. Figures 4 and 5, spiral view; figure 6, umbilical view; sample 07-Peel-116. Both samples from upper Trevor Formation, Pseudoclavulina hastata Zone.

Figs. 7-9. Trochammina rutherfordi Stelck and Wall 1955. Figures 7 and 8, spiral view; figure 9, umbilical view. Sample 07-Peel-102, upper Trevor Formation, Gaudryina irenensis Zone.

Figs. 10-12. Trochammina umiatensis Tappan 1957. Figures 10 and 12, spiral view; figure 11, umbilical view. Sample 07-Peel-21, lower Arctic Red Formation, Quadrimorphina albertensis Zone.

Figs. 13-15. Trochammina whittingtoni Tappan 1957. Figure 15, spiral view; figures 13 and 14, umbilical view. Sample 07-Peel-21, upper Trevor Formation, Pseudoclavulina hastata Zone.

Figs. 16-17. Gaudryina canadensis Cushman 1943. Sample 07-Peel-38, upper Arctic Red Formation, Gaudryina canadensis Zone.

Figs. 18-19. Gaudryina irenensis Stelck and Wall 1955. Sample 07-Peel-100, lower Trevor Formation, Gaudryina irenensis Zone.

Figs. 20-21. Gaudryina nanushukensis Tappan 1951. Sample 07-Peel-06, lower Arctic Red Formation, Quadrimorphina albertensis Zone.

Figs. 22-23. Gaudryina stotti Chamney 1978. Sample 07-Peel-34, upper Arctic Red Formation, Gaudryina canadensis Zone.

Figs. 24-25. Gaudryina tailleuri (Tappan) 1957. Sample 07-Peel-08, lower Arctic Red Formation, Quadrimorphina albertensis Zone.

Figs. 26-28. Tritaxia solea Chamney 1978. Sample 07-Peel-04, lower Arctic Red Formation, Quadrimorphina albertensis Zone.

Figs. 29-30. Tritaxia sp. Sample 07-Peel-114, upper Trevor Formation, Pseudoclavulina hastata Zone.

Figs. 31-32. Uvigerinammina manitobensis (Wickenden) 1932. Sample 07-Peel-08, lower Arctic Red Formation, Quadrimorphina albertensis Zone.

Figs. 33-34. Verneuilinoides canadensis (Cushman) 1927. Sample 07-Peel-37, upper Arctic Red Formation, Gaudryina canadensis Zone. 
$-100 \mu \mathrm{m}$
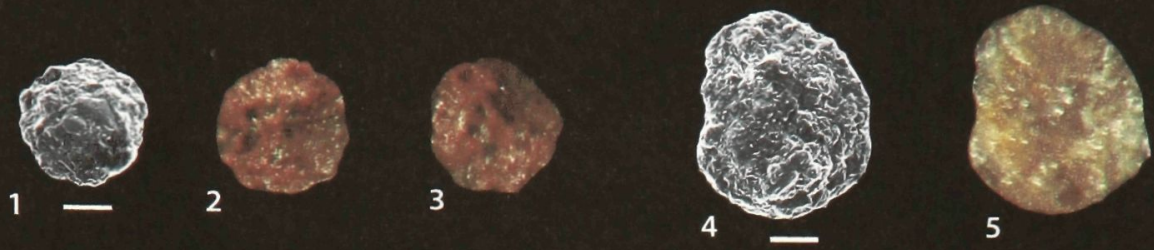

5

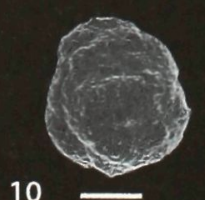

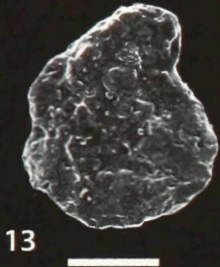

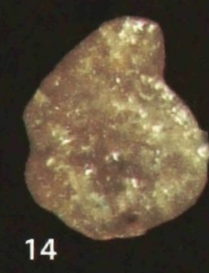

15
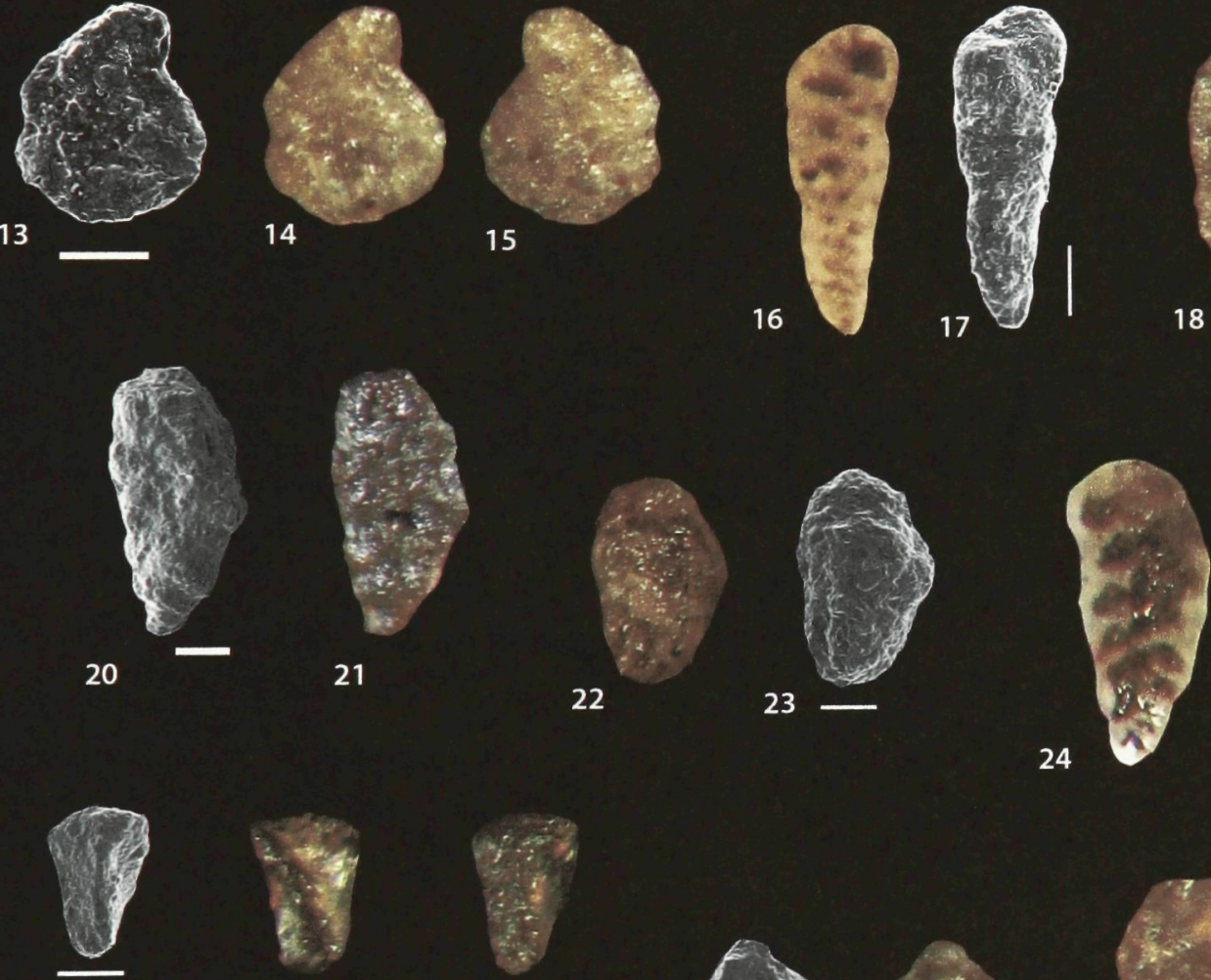

26

27

28
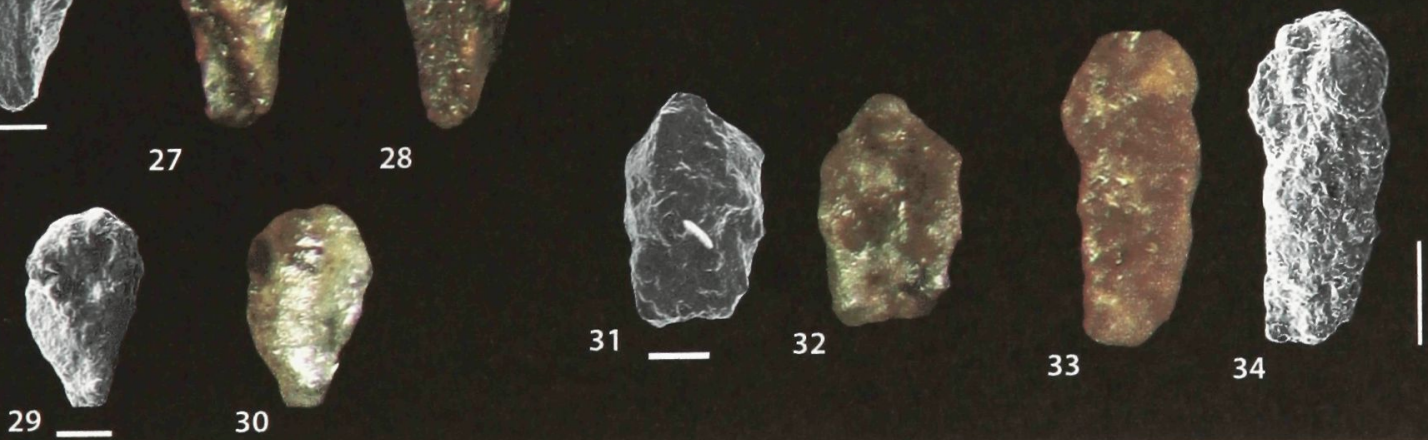
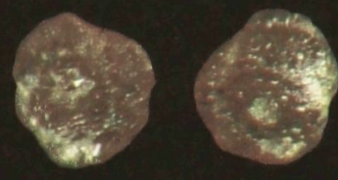

12
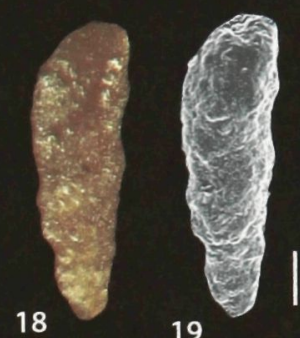

19
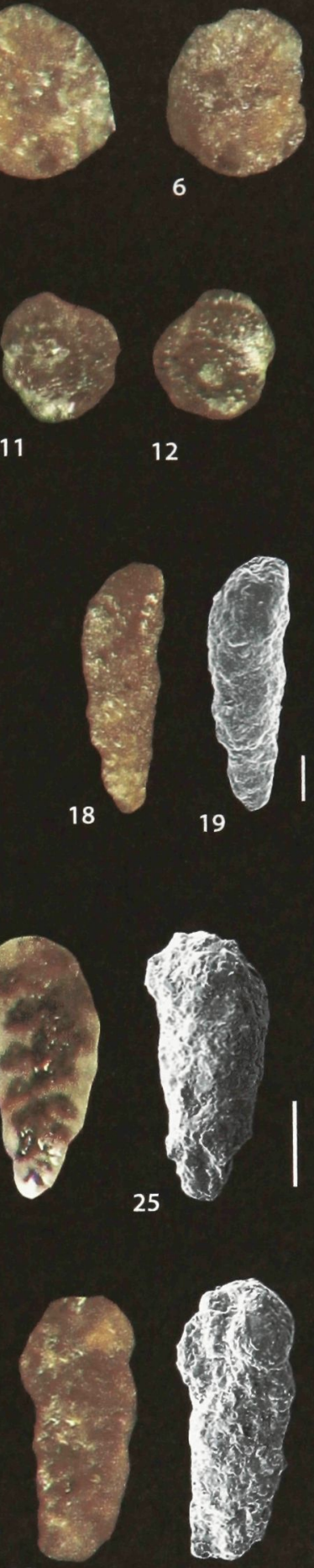

6

11

18

33 


\section{Plate 4}

Figs. 1-2. Verneuilinoides perplexus (Loeblich) 1946. Sample 07-Peel-114, upper Trevor Formation, Pseudoclavulina hastata Zone.

Figs. 3-4. Arenobulimina paynei Tappan 1957. 07-Peel-70, Slater River Formation, Fish Marker Zone.

Figs. 5-6. Pseudoclavulina hastata (Cushman) 1927. Sample 07-Peel-113, upper Trevor Formation, Pseudoclavulina hastata Zone.

\section{CALCAREOUS FORAMINIFERA}

Figs. 7-8. Dentalina dettermani Tappan 1957. Sample 07-Peel-23, lower Arctic Red Formation, Quadrimorphina albertensis Zone.

Figs. 9-10. Saracenaria projectura Stelck and Wall 1956. Sample 07-Peel-05, lower Arctic Red Formation, Quadrimorphina albertensis Zone.

Figs. 11-12. Oolina apiculata Reuss 1851. Sample 07-Peel-18, lower Arctic Red Formation, Quadrimorphina albertensis Zone.

Figs. 13-14. Oolina sp. Sample 07-Peel-101, upper Trevor Formation, Gaudryina irenensis Zone.

Figs. 15-16. Valvulineria loetterli (Tappan) 1940. Figure 7, spiral view; sample 07Peel-26. Figure 8, umbilical view; sample 07-Peel-26. Both specimens from lower Arctic Red Formation, Quadrimorphina albertensis Zone.

Figs. 17-18. Quadrimorphina albertensis Mellon and Wall 1956. Umbilical view. Sample 07-Peel-06, lower Arctic Red Formation, Quadrimorphina albertensis Zone.

Figs. 19-20. Anomalinoides sp. Sample 07-Peel-21, lower Arctic Red Formation, Quadrimorphina albertensis Zone.

Figs. 21-22. Gavelinella awunensis Tappan 1960. Spiral view. Sample 07-Peel-03, lower Arctic Red Formation, Quadrimorphina albertensis Zone. 

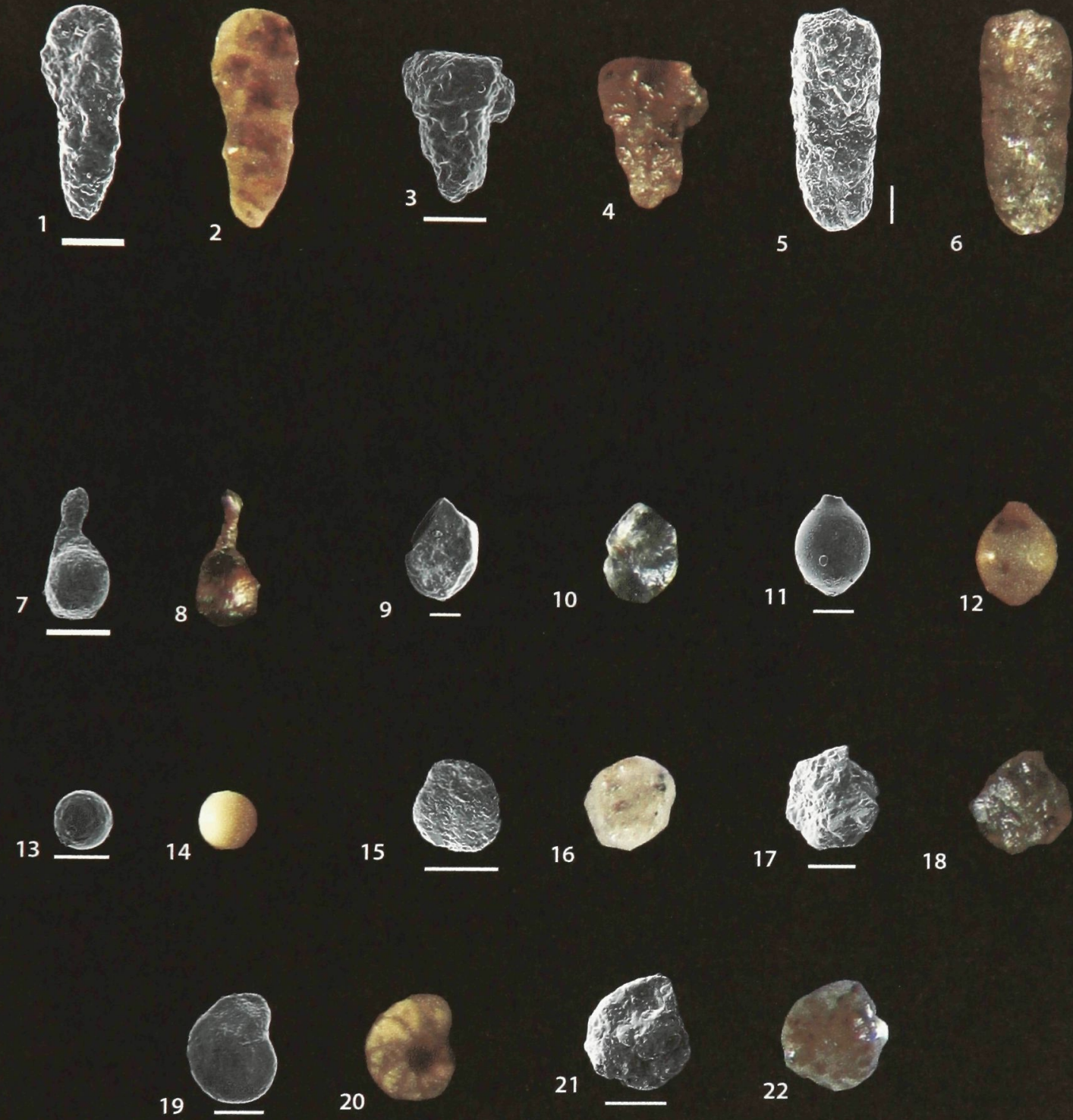
APPENDIX 


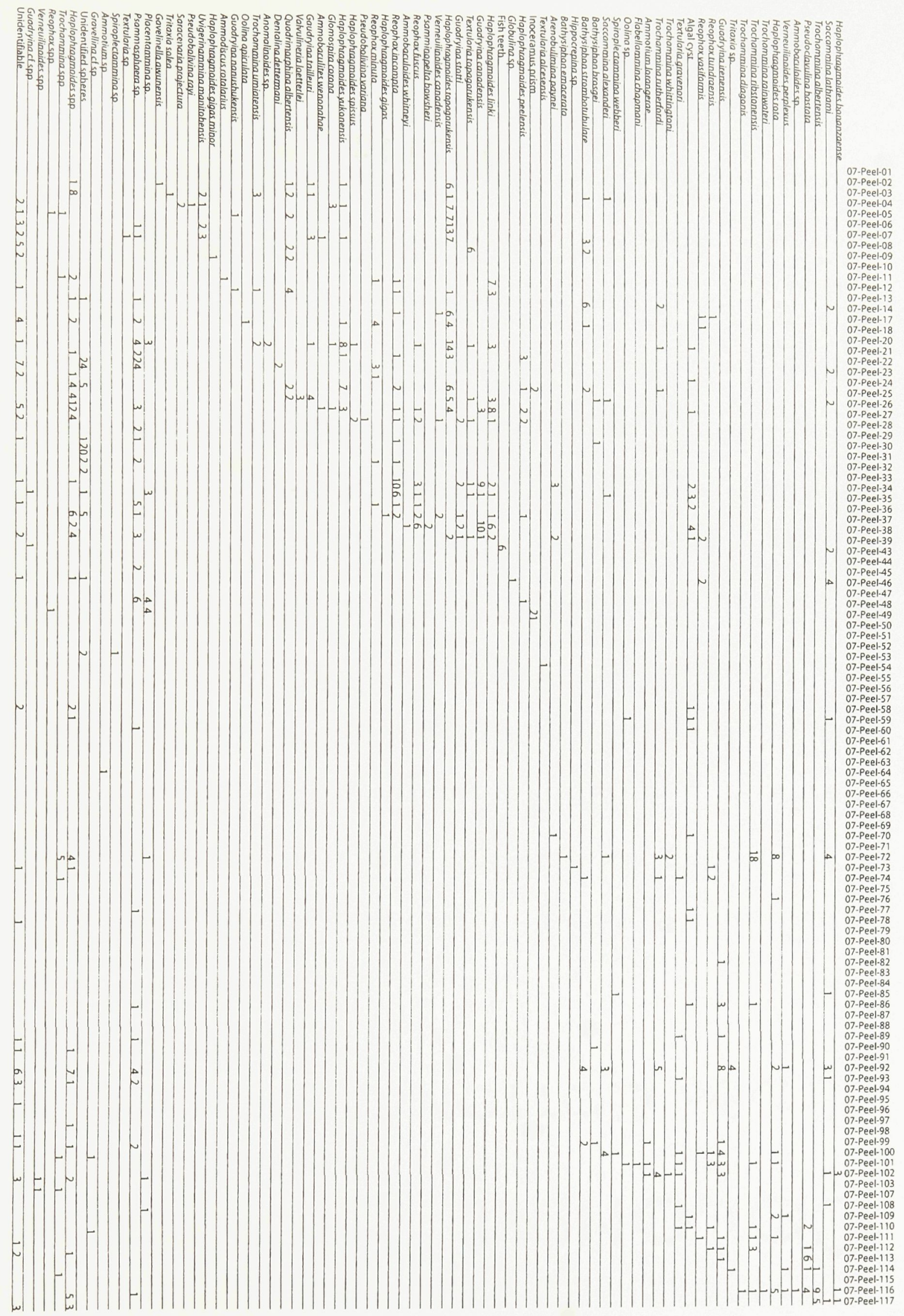

